\title{
Experiments in the Sea on the Growth-Inhibitive and Preservative Value of Poisonous Paints and other Substances.
}

\author{
By \\ J. H. Orton, D.Sc., \\ Chief Naturalist at the Plymouth Laboratory.
}

\section{With Some Chemical Analyses by the Government Chemist.}

With 20 Figures in the Text.

\section{CONTENTS.}

\section{Part I. Biological Investigations}

Introduction

Object of Research .

The substances tested experimentally

Disposal of the experimental material in the sea.

Description of the experimental material

List of experiments .

List of the chief organisms growing on or in the experimental material and controls

\section{Detailed account of the course of the experiments}

Series I. Cawsand Bay Raft

Experiment A. Wooden ladder experiment

Results of Experiment A

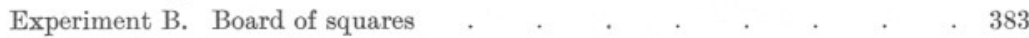

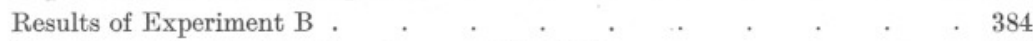

Experiment C. One-foot boards exposed to light _ . . . . . . . 384

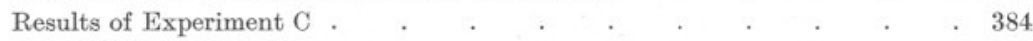

Experiment D. Shells strung on tarred rope to the bottom of the raft in

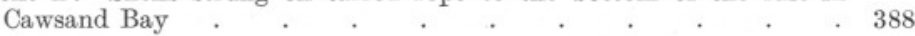

Experiment $\mathrm{D}_{2}$. Shells fixed to the bottom of the raft in Cawsand Bay . $\quad 392$

Experiment E. Shells fixed and strung inside the raft $\quad . \quad$. . . . 394

History of the general growth on the raft in Cawsand Bay . 394

The exposure of the raft and experimental material to " infection " . . . 399

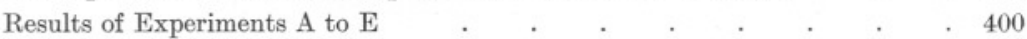

Series II. West Wharf, Millbay Docks, Plymouth . . . . . . 401

Experiment F. On 3-feet test-boards fixed at L.-W. mark . . . . . 401

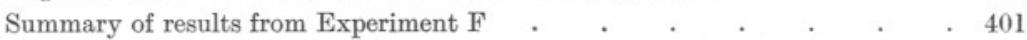

Anti-fouling and preservative values deduced from Experiment F . . . . 410

Biological (and chemical) observations on the test-boards of Experiment $\mathrm{F}$ after $3 \frac{1}{2}$ years exposure in the sea . . . . . . 410 
Experiment G. Shells strung on tarred rope around cement piles at L.-W. mark 413

The growths on individual shells in Experiment G after 14 $\frac{1}{2}$ weeks in the sea 416

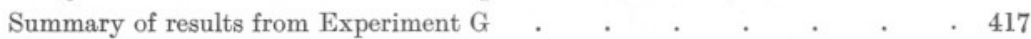

Series III. Promenade Pier, Plymouth $\quad . \quad$. $\quad . \quad$. $\quad . \quad$. $\quad . \quad .418$

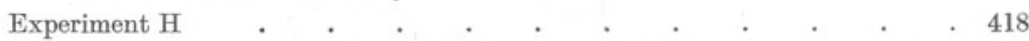

Observations on growths and paints in Experiment H $\quad . \quad$. $\quad . \quad 420$

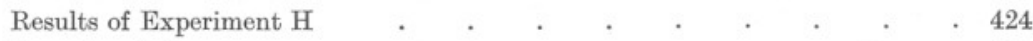

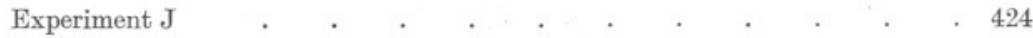

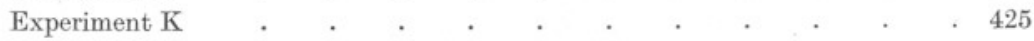

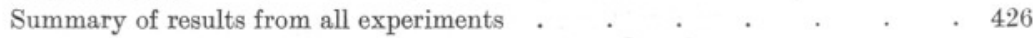

Limitations of the experiments in comparison with economic practice * $\quad$. 428

The nature of the surface covered by the experimental substance . $\quad .428$

Conditions conducive to erosion . $\quad . \quad$. $\quad . \quad$. $\quad . \quad . \quad 429$

Condition and dryness of the surfaces painted $\quad . \quad$. $\quad . \quad . \quad . \quad . \quad 429$

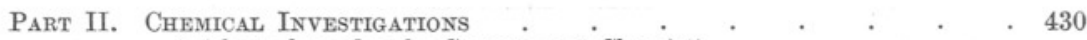

(with analyses by the Government Chemist)

Analyses of three paints which retained poisonous properties after remaining 19 months in the sea . . . . . . . . . . 431

Analyses of paints on test-boards after remaining $3 \frac{1}{2}$ years in the sea, and of corresponding original paints . . . . . . . . 432

The Government Chemist's report on chemical analyses _ . . . . . . 433

Biological observations on the Government Chemist's report . 437

Discussion of the results regarding anti-fouling paints . . . . . . . . 438

On the fundamental properties of an ideal anti-fouling paint $\quad . \quad$. . 441

PART III. Observations on the growths on the bottoms of ocean-going and local ships, and on local buoys and rafts . . . . . . . 442

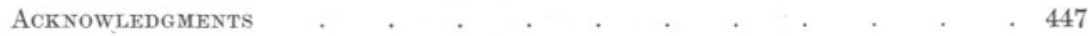

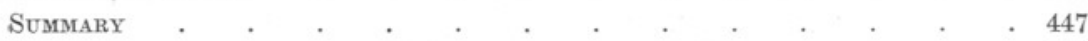

REFERENCES . . . . . . . . . . . . . . . . . . . . . . . . 451

\section{PART I. BIOLOGICAL INVESTIGATIONS.}

\section{INTRODUCTION.}

Observations on breeding $(1,1914 ; 2,3,1920)$ and experiments on the rate of growth of marine invertebrates $(\mathbf{4}, 1914 ; \mathbf{5}$ to $\mathbf{9})$ have been carried out since 1911 (excepting the war period).

The particular objects of these researches were stated $(1,1914$, p. 312) to be :-

"(1) to establish the age of common marine invertebrates.

(2) to determine the minimum age at which these forms begin to breed.

(3) to examine the rate of growth at different seasons of the year and under different conditions.

(4) to investigate the fecundity of different forms so far as possible.

(5) to collect the scattered literature on these subjects." 
During the course of that work it was realised that the general observations being made would form an invaluable control and basis for experiments, particularly for investigating the fundamental properties and the efficacy of anti-fouling paints, i.e. paints having usually poisonous properties. These paints, as is well known, are used on the bottoms of ships to prevent marine organisms from settling and growing there. Slight growths on the bottom of a ship seriously reduce the speed of the vessel and increase the time of making a given passage in proportion to the amount of such growth, i.e. fouling. The debasement of the immense amount of capital involved in the loss of time in passage due to the fouling of vessels, and in their docking for scraping and repainting the bottom, is a sufficient indication of the great economic importance of methods for maintaining the bottoms of ships free from growths. In this pioneer research, which was begun in 1919, it was found that certain so-called anti-fouling paints had only a slight anti-fouling value (even on stationary objects), while others retained a poisoning property up to $3 \frac{1}{2}$ years. Publication of the work has been delayed by unavoidable circumstances.

\section{OBject of the Research.}

The object of the research was to compare growths on anti-fouling paints (A.F.P.) on experimental material composed of painted shells and painted boards and controls placed in the sea in a number of different situations, while observing normal general growth in the same and similar situations in the locality at the same time. By observing the experimental material over a period of years it was possible to determine the age at which particular paints lost their anti-fouling property, and to investigate by chemical analyses the concentration of the poisonous ingredients left in the paints when the poisonous property was lost, or near the point of being lost.

It is known that marine organisms grow more abundantly in certain localities or at certain tidal levels than in others $(\mathbf{1 0}, \mathbf{1 1})$. Therefore to test the value of anti-fouling paints in the sea it is advisable to expose these to as great a variety of conditions - to ensure as great a variety of infection from the larvæ or young of different marine organisms - as is possible, since some marine organisms (e.g. certain algæ and Tubularia) are undoubtedly less affected by anti-fouling paints than are others. Moreover, in English waters there is undoubtedly on the whole a seasonal variation in growth and reproduction (see 1 and p. 399), and it is a fact that all growths on the bottom of floating ships begin by young or larval freeswimming forms settling on the bottom of the ship. Thus the seasonal variation in reproduction in England and other temperate waters renders surfaces covered by anti-fouling paints liable to infection (and therefore 
testing) by larvæ less in the winter period than at any other. All these considerations - in addition to the probability of infection in the infective period-are important in testing the value of an anti-fouling paint. To realise the efficacy of the poisonous paints and other substances the reader is directed especially to the records of normal growth given in 1, 1914 ; and pp. 396-399, 416, 420, and 424 herein.

\section{The Substances Tested Experimentally.}

The following paints and other materials were tested in one or more experiments: numbers I to VI and number XI being proprietary compositions the same as, or similar to, those placed on the market ; No. IX, ship-chandlers' black varnish, being coal tar diluted to the required thinness by naphtha :-

\begin{tabular}{|c|c|c|c|}
\hline \multirow{2}{*}{$\begin{array}{c}\text { No. of } \\
\text { Paint } \\
\text { or other } \\
\text { substance. }\end{array}$} & -2 & \multicolumn{2}{|r|}{ LYY. } \\
\hline & Designation. & & \\
\hline I & Anti-fouling composition & Reddish brown & $\mathrm{A}-\mathrm{F}$ \\
\hline II & & Dark green & $\mathrm{A}-\mathrm{F}$ \\
\hline III & Anti-corrosive only, composition & Black & $\mathrm{A}-\mathrm{C}$ \\
\hline IV & Anti-fouling composition & Reddish brown & $\mathrm{A}-\mathrm{F}$ \\
\hline $\mathrm{V}$ & Anti-corrosive only & Black-bronze & $\mathrm{A}-\mathrm{C}$ \\
\hline VI & Anti-fouling composition & Red & $\mathrm{A}-\mathrm{C} \& \mathrm{~A}-\mathrm{F}$ \\
\hline VII & Clean surface (Control) & $\begin{array}{l}\text { White or greyish } \\
\text { white }\end{array}$ & \\
\hline VIII & Red oxide of iron & Red & \\
\hline IX & Black varnish & Black & \\
\hline $\mathrm{x}$ & Tar & Black & \\
\hline XI & Anti-fouling composition & Light green & A-F \\
\hline $\mathrm{XII}$ & Aluminium paint & Silvery & \\
\hline XIII & Copper sheets & Reddish brown & \\
\hline XIV & Zine sheets & Metallic grey & \\
\hline XV & A Grey paint & Grey (opaque) & \\
\hline
\end{tabular}

Disposal of the Experimental Material in the Sea.

In order to expose the anti-fouling paints and other substances to different conditions in the sea, experiments were carried out in three situations in Plymouth Sound, namely :-

(1) on an experimental raft submerged in Cawsand Bay.

(2) on the piles of the West Wharf, Great Western Railway, in Millbay Docks, Plymouth, at the level of low-water spring tides.

(3) on the piles of the Promenade Pier, at the level of low-water spring tides.

* A-F signifies anti-fouling; A-C anti-corrosive. 
In these three situations the general conditions are somewhat different.

(1) In Cawsand Bay the water is relatively clean, clear, and usually of high salinity, but the tidal current is slight. In this situation the experimental material was constantly immersed on a wooden raft $(20 \times 5 \times 2$ feet) at a depth of 1 to 2 feet below the surface. One of the experiments was carried out in direct exposure to light, but the three others were in shade or subdued light. Wave-action is strong only with easterly winds, but the experimental material would be almost continuously in motion due to the roll and pitch and up-and-down movement of the raft.

(2) At the Great Western Railway Wharf the water conditions are more foul than at the Promenade Pier, for besides pollution from the adjacent city sewer, fouling occurs from $(a)$ occasional discharges of foul water from the inner dry dock, $(b)$ occasional discharges of warm and foul water from vessels unloading alongside the wharf, and $(c)$ the loss of grain and china clay from vessels loading and unloading alongside. Tidal currents are negligible in this situation; at dead low-water spring tides the experimental material would be exposed only to diffuse daylight. The salinity in this locality is estimated as being not very different from that prevailing at the Promenade Pier $(2,29)$.

(3) At the Promenade Pier the water must be regarded as mostly heavily charged with bacteria derived from the adjacent sewer outfall, but relatively pure on the latter part of the flood of spring tides. The salinity is variable and of a lower mean than in Cawsand Bay, but, as in Cawsand Bay, the tidal current is slight. The material was mostly in a subdued light (under water under the Pier), but would be exposed to air,wind, and daylight (but not to direct sunlight) at the middle of the day $(11$, p. 280$)$ at spring tides which were slightly lower than the average. Wave-action is fairly strong with south to east winds.

\section{Description of the Experimental Material.}

The anti-fouling properties of the paint compositions and the materials were tested by painting them on scallop shells (Pecten maximus) and on test-pieces of wood (Elm and Deal). The painted shells were previously bored with holes of a distinctive size or position, and either strung with tarred or clean yacht manilla around piles in the sea and inside or underneath the raft. Other shells were nailed on the bottom of the Cawsand Bay raft ; test pieces of wood were nailed on to old Jarra wood piles at the Great Western Railway Wharf (G.W.W.), and some were tied with tarred rope to cement piles in the same wharf.

Two good coats of paint composition (or other material) were given to all shells and test-pieces of wood, i.e. battens. In all cases the application 
was made as thoroughly as it can be by brushing the paints well in on to dry surfaces and with rare exceptions the painted surfaces were well dried before being immersed in the sea. Thirty shells and five wooden test-pieces were used to test each proprietary anti-fouling paint and other substance at Cawsand Bay; and ten shells and one batten to test each of them at the Great Western Wharf, Millbay Docks. One anti-fouling paint was tested by sixteen shells - as were several other materials-at the Promenade Pier, but complete details of the tests are best given with each experiment. In all experiments with shells a number of clean shells equal to or greater than the number of the painted shells was put out with the latter as a control experiment; untreated test-boards were also used as controls alongside treated battens.

\section{LIST (II) OF EXPERIMENTS.}

The following list of the experiments carried out will be useful for reference :-

Series I.-Cawsand Bay. Experiments on and in a submerged but floating raft* (see Figs. 19 and 20, pp. 426 and 427) put out in the sea on July 16th, 1919, and moored in 3 fathoms of water about 150 yards N.W. by N. from the end of the pier at Pier Cove (Pier Cellars). The raft was stoutly made of a wooden frame 20 feet by 5 feet by 2 feet deep, on which were nailed 4 by 1-inch battens of wood on the bottom and sides, so as to leave about 1 inch of space between adjacent battens. It was divided into three compartments, over which lids-having the same structure as the bottom and sides-were fitted. Mooring was effected by a central swivelled attachment at the bottom of the raft, and sufficient slack mooring chain was allowed to permit of the raft being turned over completely.

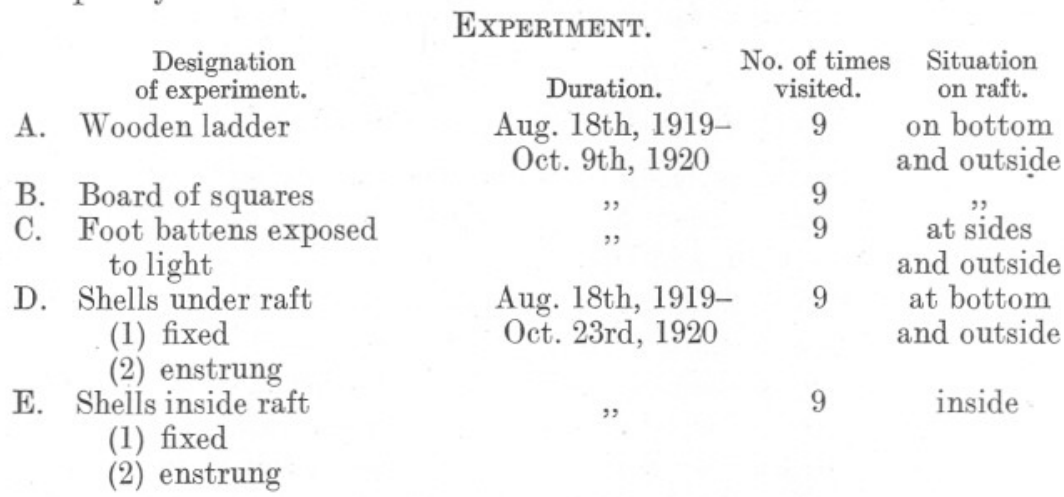

* This raft was originally designed by Dr. E. J. Allen for acclimatising marine animals (to low pressures) prior to transferring them from the sea to the Plymouth Aquarium tanks. By a modification of the structural parts by the writer, similar smaller rafts were designed for the study of the bionomics of Teredo by Potts (12, 1923) and the Institute of Civil Engineers (13, 1924). 
Series II.-West Wharf, Millbay Docks, Plymouth. Shells were strung on tarred rope and secured around cement piles at low-water spring tide level. Boards were nailed to old Jarra piles at about low-water spring tide level.

\section{Experiment.}

F. Three-feet boards

(red pine)

G. Shells on rope
No. of inspections. Situation. Aug. 27th-28th, 1919- $15 \quad$ L.W. spr. March 7th, 1923 Aug. 28th, 1919April 23, 1921

Series III.-Promenade Pier, Plymouth. Shells and sheets of copper and zinc were strung on tarred and clean rope around the inner piles under the Pier at low-water spring tide level.

Experiment.

H. Shells and metal sheets on rope

J. Raft, Cawsand Bay

K. Bathing rafts, Plymouth Sound

\begin{tabular}{|c|c|c|}
\hline Duration. & $\begin{array}{l}\text { No. of inspec- } \\
\text { tions. }\end{array}$ & Situation. \\
\hline $\begin{array}{c}\text { June 18th, 1919- } \\
\text { Feb. 21st, } 1920\end{array}$ & 8 & L.W. spr. \\
\hline March-Oct., 1912 & z & $\begin{array}{l}\text { within the } \\
\text { battens }\end{array}$ \\
\hline April-Oct., 1912-28 & - & $\begin{array}{l}\text { on lower } \\
\text { surface }\end{array}$ \\
\hline
\end{tabular}
surface

List (III) of the Chief* Organisms growing on oR IN the Experimental Material and Controls.

Protozoa.

Folliculina ampulla, 20, p. 257

\section{Porifera.}

Sycon coronatum, 185

Leucandra fistulosa

Leucosolenia sp., 185

Halichondria panicea, 186

Halichonitria sp.

Hymeniacidon sanguineum, 186

\section{Cgelenterata.}

TUBULARIA LARYNX, 190

Plumularia pinnata, 199

OBELIA GENICULATA, 193

Bougainvillea ramosa, 189

Clytia Jolınstoni, 193

Gonothyrcea Loveni, 194

Actinoloba dianthus, 205

(=Metridium senile)

Sagartia viduata Gosse, 18, p. 111

(=S. anguicoma [Price])
Polycheta.

Pomatoceros triedeter, 232

HYDROIDES NORVEGICA, 232

Serpula vermicularis, 232

Sabella pavonina, 231

Polydora ciliata, 227

Sabella sp., small unidentified

\section{PolyzoA.}

Umbonula verrucosa, 262

BUGULA FLABELLATA, 260

Membranipora sp., 260

CELlUlaria sp., prob. neritina

\section{Echinodermata.}

Antedon rosacea, 207

Echinus miliaris, 210

\section{Mollusca.}

T'ergipes despectus, 279

Galvina exigua, 279

Galvina picta, 279

* The names given in capitals are the predominant organisms in each group causing the fouling of the ships' bottoms and buoys. The figures in italics refer to pages in reference 10 . 
Facelina Drummondi, 280

Dendronotus frondosus, 282

TEREDO NORVEGIOUS

Pecten opercularis, 287

ANOMIA ACULEATA

MYTILUS EDULIS, 286

Helcion pellucida, 268

Patella vulgata, 268

Concholepas peruviana

\section{Crustacea.}

BALANUS sp., probably crenatus, 237

B. perforatus, 237

B. TINTINNABULUM, 19, p. 212

LIMNORIA LIGNORIUM, 243

CHELURA TEREBRANS, 241

$J_{A S S A}$ sp., probably falcata, 241

CONCHODERMA VIRGATUM, 19, 144

C. AURITUM, 19, p. 144

LEPAS HILLI, 19, p. 110

L. ANATIFERA, 19, 108

Nautilograpsus minutus (=Planes),22, p. 135
Pilumnoides perlatus, 23, p. 544. Plate 50

Cancer pagurus juv., 256

Porcellana longicornis, 254

Carcinus monas, 257

Leander serratus, 249

\section{Tunicata.}

Diplosoma Gelatinosum, $2 \%$, p. 87 (=Leptoclinum Hartmeyer, 28, p. 1455)

BOTRYLLUS VIOLACEUS, 298

Botrylloides rubrum, 298

Morchellium argus, 297

ASCIDIELLA ASPERSA, 296

CIONA INTESTINALIS, 296

Molgula ampulloides

\section{ALG杘.*}

LAMINARIA SACOHARINA

L. digitata

Ulva latissima

ENTEROMORPHA INTESTINALIS

\section{Detailed Account of the Course of the Experiments.}

\section{SERIES I. CAWSAND BAY RAFT.}

Experiment $A$. Wooden ladder experiment.

In this experiment a ladder was made 3 feet long with eight rungs and fixed across the bottom of the raft. The side pieces of this ladder consisted of two battens of elm, 3 feet by 4 inches by 1 inch, while the rungs were made of smaller battens of elm, 1 foot by 2 inches by 1 inch. Six of the rungs were painted with the proprietary paints I to VI, noted on page

FIG. 1.- Showing the arrangement of the test-pieces treated with substances I to VI and VIII in the ladder experiment (A) on the Cawsand Bay Raft, begun August 18th, 1919 (reduced ca. ${ }^{2}$ ).

Each rung of the ladder was painted with the substance designated by the number (see p. 376) as well as the rectangular areas opposite the end of each rung. No. VII was left untreated as a control.

FIG. 2.- Same as Fig. 1, and showing the distribution of the growths of Tubularia larynx found on the test-pieces on September 30th, 1919, after 6 weeks' exposure in the sea.

I, II, and IV are clean and VI has a little growth; all the other test-pieces have acquired heavy growth.

FIG. 3.-Same as Fig. 1, and showing the distribution of various growths on October 9th, 1920 , after about 14 months' exposure in the sea.

The growths shown are chiefly Ciona and Diplosoma with some Pomatoceros, Anomia, and colonies of hydroids.

I. II, and IV are still almost clean, but all the other test-pieces have a luxuriant growth.

Figs. 2 and 3 are reproduced from field sketches and notes. The taking of photographs at a later stage (as intended) was prevented by loss of the raft in a gale.

* Many unidentified, including a brown filamentous Alga and a Polysiphonia sp. 
FIG.1 AUG. $18 \quad 1919$

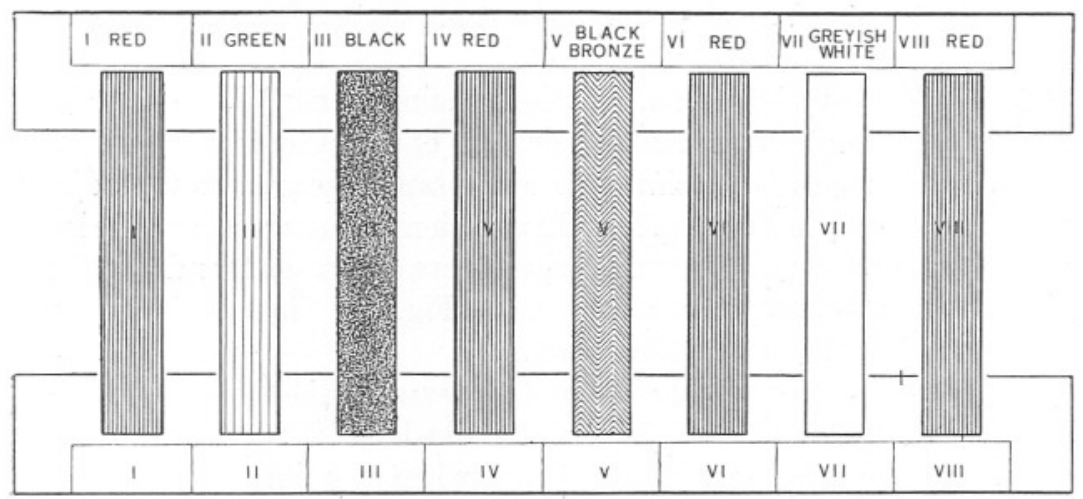

FIG. 2 SEPT 301919

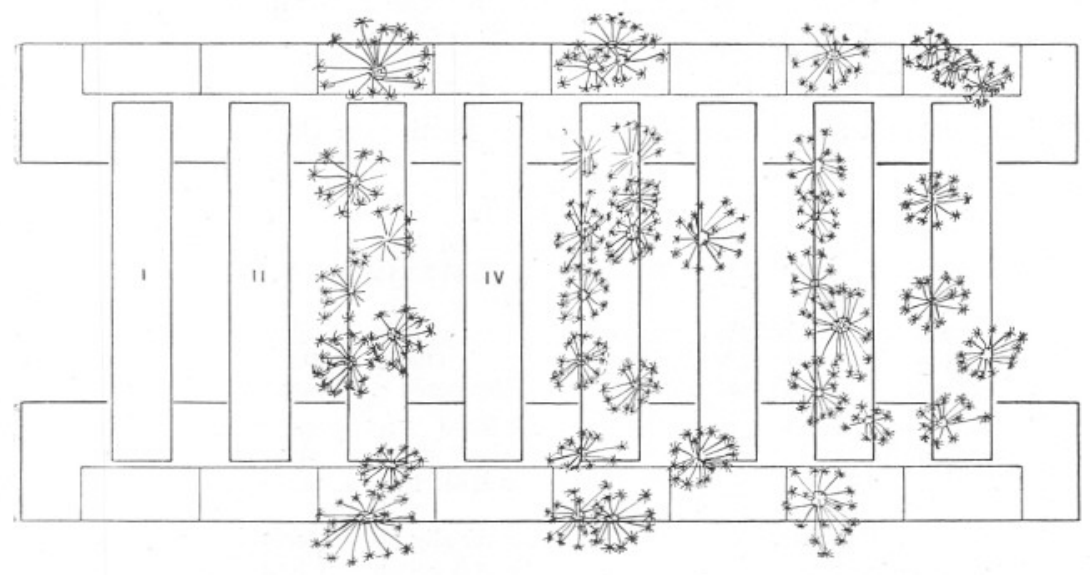

FIG. 3 OCT. $9 \quad 1920$

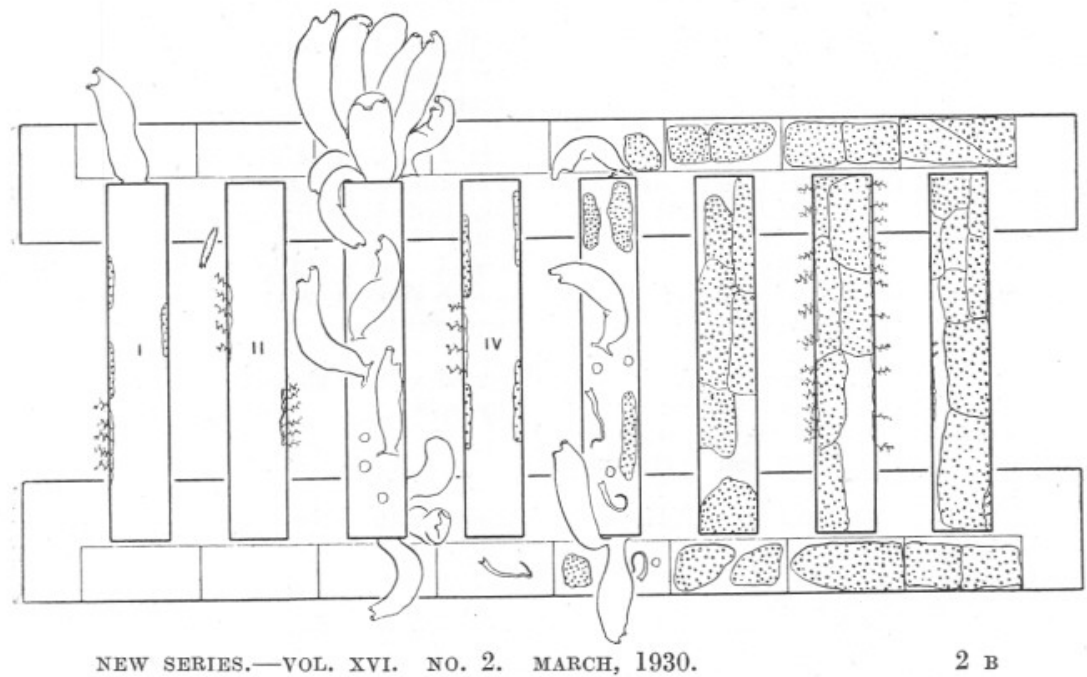


376, one (VII) was left clean, and the remaining one (VIII) painted with red oxide (of iron) paint. An area on each of the outer sides of the ladder opposite the rungs was painted with the same material as the adjacent rung, as is shown in Fig. 1, p. 381. In addition the inner sides of the ladder were painted respectively with coal-tar between rungs 2 and 3 and with black varnish between rungs 5 and 6 (see Fig. 1). The remaining part of the sides of the ladder was left clean.

The ladder was fixed to the raft and immersed in the sea on August 18th, 1919. On September 30th, 1919, six weeks later, it was examined, with the result shown in Fig. 2, page 381, and when examined on the last occasion, on Oetober 9th, 1920, it showed the growths depicted in Fig. 3, page 381 . This experiment was not reported on again after October 9th, 1920, and the experiment, and indeed all the experiments on the raft, were lost after a gale on December 25th-26th, 1920.

In Table I below are given reports on the growths found on the two visits recorded and the condition of the paints on October 9th, 1920.

\section{TABLE I.}

Reports on Ladder Experiment (a).

$\begin{array}{cc}\begin{array}{c}\text { Designation } \\ \text { and colour } \\ \text { of surface. }\end{array} & \begin{array}{c}\text { Growths found on } \\ \text { Sept. 30th, 1919 } \\ \text { (exposed 6 weeks). } \\ \text { Reddish brown } \\ \text { A-F }\end{array} \\ \text { None } \\ \text { II } & \text { None } \\ \text { Green, A-F } & \\ \text { III } & \begin{array}{c}\text { Large growth of Tubu- } \\ \text { laria and some small } \\ \text { Black } \\ \text { A-C }\end{array} \\ \text { Pomatoceros } \\ \text { IV } & \text { None } \\ \text { Reddish brown } & \\ \text { A-F } & \end{array}$

Large growth of Tubularia and some small Pomatoceros

Slight growth of colonies of Tubularia

Growths found on Oct. 9 th, 1920 (exposed c. 14 months).

Condition of paint on Oct. 9 th, 1920.

A little Diplosoma, a few small hydroid colonies, and a little Podoceros

Practically clean : only a few small colonies of hydroids
Enormous Ciona and some Apparently Anomia good

A little Diplosoma and Fairly good hydroids and one large Pomatoceros

Large Ciona, some Anomia, Apparently Pomatoceros, Diplosoma good and hydroids

Covered with Diplosoma M o s t l y which also extends in parts was hed over the paint off

Large growth of Tubularia and some small Pomatoceros rather less than in III and V

Covered with Diplosoma and Originally hydroids clean

ureyishtrea

VIII

Same as on VII

Covered with Diplosoma

M o s t 1 y washed off 


\section{Results of Experiment A.}

In this situation and under the conditions described the poisonous paints I, II, and IV retained their growth-inhibiting properties during about fourteen months and only permitted slight growth on parts where the paint had probably washed off more rapidly than in others. The anti-corrosive paints III and V, as well as the clean board VII and the red oxide board VIII, all developed extensive or very extensive growth, within as short a period as six weeks, and developed heavy growths subsequently. The anti-fouling paint VI also developed a slight growth in six weeks and a heavy covering of growth later, and is therefore inefficient as an anti-fouling paint under these conditions. At the end of the experiment, however, paints III and V were in a better condition than any of the others. It is of interest to note that the red oxide was mostly washed away in just over a year. The anti-fouling paints II, IV, and I were efficient in this order after about fourteen months in the sea under these conditions.

\section{Experiment B. Board of Squares.}

In this experiment a single piece of wood, 3 feet by 4 inches by 1 inch, was prepared by painting 4 inch squares with each of the paints I to VI and VIII, and leaving one square (VII) and a strip of 2 inches at each end clean (see Fig. 4, p. 385). This board was screwed on the bottom of the Cawsand Bay raft in the same way as in the ladder experiment (p. 380) and at a little distance from it. The board was screwed to the bottom of the raft and exposed to the sea on August 18th, 1919; it was examined on September 30th, 1919, after being in the sea six weeks, and last seen on October 9th, 1920. On September 30th, 1919, the growth found on the board is shown in Fig. 5, p. 385, and is described as follows :-

\section{Table II. Report on Board of Squares Experiment,} September 30Th, 1919.

Designation and colour of surface.

I Reddish brown ; A-F

II Green; A-F

III Black; A-C

IV Reddish brown; A-F

$\mathrm{V}$ Black bronze; $\mathrm{A}-\mathrm{C}$

VI Reddish brown; A-F None.

Growths found on Sept. 30th, 1919 (exposed 6 weeks).

None.

None.

Three colonies of Tubularia.

None.

Three colonies of Tubularia; some Obelia with Nudibranchs and spawn.

VII Greyish white; untreated One colony of Tubularia and some small Pomatoceros.

VIII Red; A-C Also one colony of Tubularia and some small Pomatoceros.

Ends Greyish white; untreated One colony of Tubularia on one end. 
On October 9th, 1920, this board was seen for the last time, and found at that time to have similar growths on each paint or surface as was shown on the rungs of the ladder experiment (see Table I, p. 382). No special report on this board was written down on this day at the moment of observation owing to the advent of bad weather conditions.

\section{Results of Experiment $B$.}

The results from Experiment B were in all respects similar to those obtained from Experiment A (see p. 383).

\section{Experiment $C$.}

On boards 1 foot by 2 inches by 1 inch, treated in the same way as the rungs in the ladder experiment (see p. 380) and exposed to light.

These boards were placed vertically on the outside at the ends of the sides of the raft with the bottom end of each board flush with the bottom of the raft. The boards were thus placed 1 to 2 feet below the surface of the water and were exposed to direct water-filtered sunlight, and possibly at times for an instant to direct light.

As in the case of experiments $\mathrm{A}$ and $\mathrm{B}$, this experiment was begun on August 18th, 1919, examined on September 30th, 1919, and last seen on October 9th, 1920. The reports given in Table III show the varying degrees to which growth was inhibited in this habitat.

\section{Results of Experiment $C$.}

After six weeks in the sea the same four substances, namely I, II, IV (and VI), resisted growths of seaweed as they did of animals in the contemporaneous experiments A and B (see pp. 383-4). In the same period, i.e. August 18th to September 30th, 1919, the remaining boards III, V, VII, and VIII all became covered with a growth of seaweed, probably mainly of Enteromorpha. Contrary to experiments A and B, however, slight growths of other seaweeds manifested themselves on the former (and poisonous) compositions already on March 2nd, 1920, only seven months after immersion. After about fourteen months in the water the compositions II, IV, and I had definite growths of a short filamentous brown Alga, in contrast with the slight growths on these compositions in situations exposed only or mainly to animal growth, i.e. under the raft, while the remaining boards after fourteen months all had Laminaria as well as other growths. The paint compositions II and IV were the only ones not permitting growth of Laminaria, and there can be little doubt that they were exposed to the same or a similar degree of "infection" as the others. 
FIG. 4

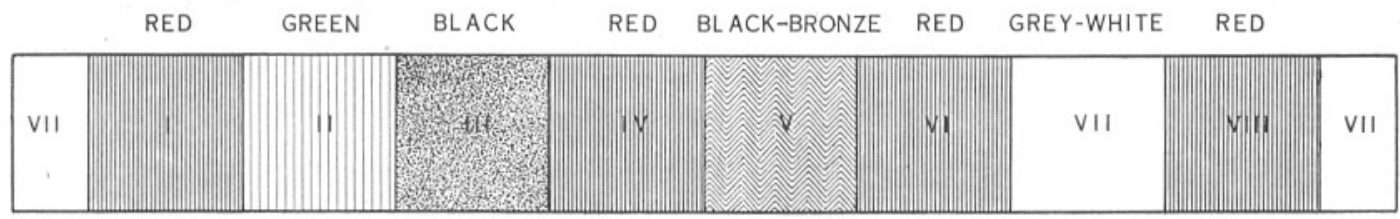

FIG. 5

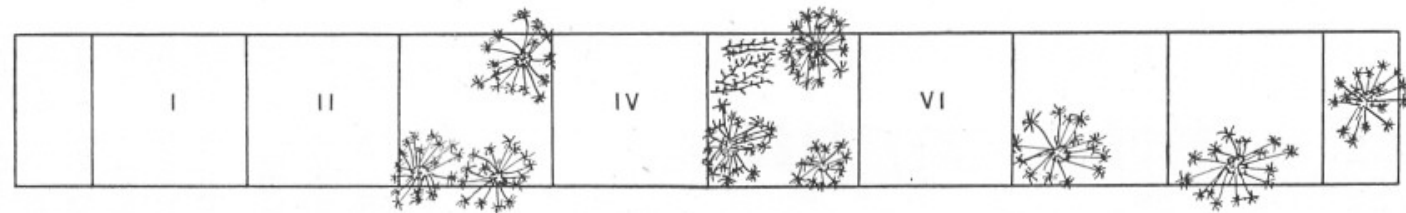

FIG. 6

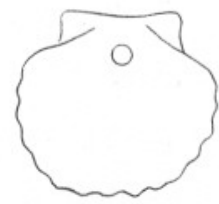

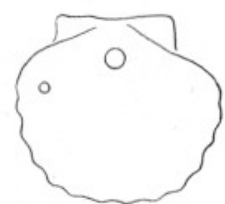

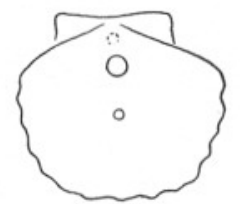

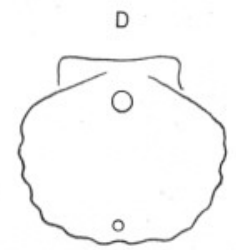

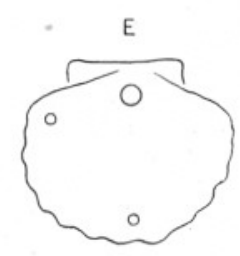
Squares experiment (B) begun August 18th, 1919, on the Cawsand Bay Raft.

Frg. 5.-Same as Fig. 4, showing the distribution of colonies of Tubularia on the Board of Squares experiment (B) on September 30th, 1919, after 6 weeks' exposure in the sea.

I, II, IV, and VI are clean, while all the other test-areas have acquired and permitted luxuriant growths of Tubularia.

Fig. 6.- Scheme of the borings made in the painted scallop shells to serve for their identification while exposed in the sea.
A. One sub-central hole
C. $\quad " . \quad$ and a central or umbonal hole.
D. .. and a ventral hole.
entral hole.
III Black ; I Red : II Dark green : III Aluminium.
IX Black ; IV Red ; XI Light Green.
VIII Red.
X Black-bronze : VI Red.
The untreated shells (VII) had also in most experiments only one hole, sub-central. 
TABLE III.

Reports on Growths on Test-pieces Exposed to Light on the CaWSAND Bay RaFt.

\begin{tabular}{|c|c|c|c|}
\hline $\begin{array}{l}\text { Designation and } \\
\text { colour of surface }\end{array}$ & $\begin{array}{c}\text { Growth on } \\
\text { Sept. 30th, 1919 } \\
\text { (exposed } 6 \text { weeks). }\end{array}$ & $\begin{array}{c}\text { Growth on } \\
\text { March 2nd, 1920 } \\
\text { (exposed } 7 \text { mths.) }\end{array}$ & $\begin{array}{c}\text { Growth* on } \\
\text { Oct. } 9 \text { th, } 1920 \\
\text { ). (exposed c. } 14 \text { mths.). }\end{array}$ \\
\hline$\underset{\mathrm{A}-\mathrm{F}}{\mathrm{I}}$ & None & & $\begin{array}{l}\text { Small Laminaria and } \\
\text { scum of a brown } \\
\text { Alga }\end{array}$ \\
\hline $\begin{array}{c}\text { II } \\
\text { Green } \\
\mathrm{A}-\mathrm{F}\end{array}$ & None & $\begin{array}{l}\text { All } \\
\text { with } \\
\text { some } \\
\text { growth of } \\
\text { weed. }\end{array}$ & $\begin{array}{l}\text { Scum of brown Alga } \\
\text { only }\end{array}$ \\
\hline $\begin{array}{c}\text { III } \\
\text { Black } \\
\text { A-C }\end{array}$ & $\begin{array}{l}\text { Large growth of seaweeds } \\
\text { (probably mainly } \\
\text { Enteromorpha) }\end{array}$ & & $\begin{array}{l}\text { Small Laminaria, Bal- } \\
\text { anus and a scum of } \\
\text { brown Alga }\end{array}$ \\
\hline $\begin{array}{c}\text { IV } \\
\text { Reddish brown } \\
\text { A-F }\end{array}$ & None & $\begin{array}{l}\text { The } \\
\text { Green } \\
\text { board }\end{array}$ & $\begin{array}{l}\text { Scum of brown Alga } \\
\text { only }\end{array}$ \\
\hline $\begin{array}{c}\mathrm{V} \\
\text { Black-bronze }\end{array}$ & $\begin{array}{l}\text { Large growth of seaweed } \\
\text { (probably mainly } \\
\text { Enteromorpha) }\end{array}$ & $\begin{array}{l}\text { appears } \dagger \\
\text { to have } \\
\text { relatively } \\
\text { little }\end{array}$ & $\begin{array}{l}\text { Small Laminaria, small } \\
\text { Ulva, good colony } \\
\text { of red weed and } \\
\text { Anomia }\end{array}$ \\
\hline $\begin{array}{c}\text { VI } \\
\text { Reddish brown } \\
\text { A-F }\end{array}$ & None & $\begin{array}{l}\text { growth } \\
\text { on } \\
\text { it. }\end{array}$ & $\begin{array}{l}\text { Laminaria of medium } \\
\text { size, Enteromorpha } \\
\text { and Ulva }\end{array}$ \\
\hline $\begin{array}{l}\text { VII } \\
\text { Greyish white } \\
\text { untreated }\end{array}$ & $\begin{array}{l}\text { Covered with a growth of } \\
\text { weed (probably mainly } \\
\text { Enteromorpha) }\end{array}$ & & $\begin{array}{l}\text { Laminaria of medium } \\
\text { size, Enteromorpha } \\
\text { and Ulva }\end{array}$ \\
\hline $\begin{array}{l}\text { VIII } \\
\text { Red } \\
\text { A-C }\end{array}$ & $\begin{array}{l}\text { Covered with a growth of } \\
\text { weed (probably mainly } \\
\text { Enteromorpha) }\end{array}$ & $\frac{f}{y}$ & do. \\
\hline
\end{tabular}

The boards were fixed on one side of the raft in groups of four near each end in the following order and relation to the ends of the raft:-

(a) One end, IV, III, I, II-middle-V, VIII, VI, VII, the other end (b).

At the $(a)$ end I and III grew Laminaria, as well as those at the $(b)$ end, and Laminaria was growing over most of the lower sides of the raft. On the other hand, all the boards at the end $(a)$ had a brown scum and no green weeds (Enteromorpha and Ulva), while the boards at the $(b)$ end all grew green weeds; the examination of these four boards had to be performed rapidly, and it is not now certain that these boards had not also a growth of the brown algal scum.

* All the painted boards had more or less paint remaining, but a careful examination could not be made on this date owing to the onset of bad weather.

$\dagger$ There was too much wind and wash of the waves to examine the boards thoroughly on this visit. 
Thus, although it is unlikely, it is possible that the general conditions were not favourable for the settling and growth of the green weeds at the $(a)$ end of the raft. There was a good general growth of the green weeds on the top and sides of the raft, but the detailed distribution was not recorded at the time, and in future experiments it is clear that

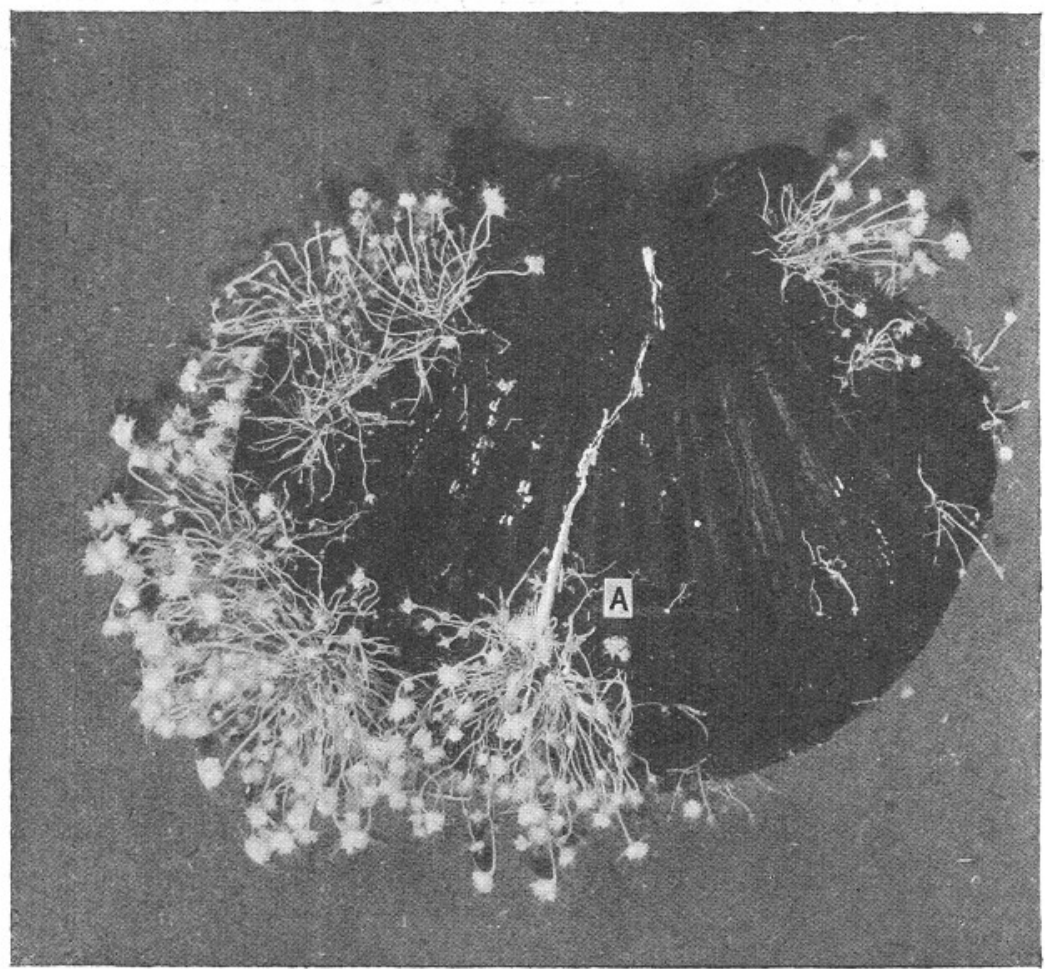

Fig. 7.-Photo of shell with a heavy growth of Tubularia larynx from Experiment D, Cawsand Bay raft, coated with substance No. V; exposed in the sea from August 18th, 1919, to September 30th, 1919. (Photo by D. P. Wilson.)

The distinguishing mark of the shell, a small hole ventral, is shown below A, near the lower margin of the shell to the right of the white vertical line in the middle of the shell. The shell was broken into two parts to permit the preservation of the Tubularia in a bottle. A large colony of this hydroid has been taken from the shell in order to expose the distinguishing hole.

periodical observations of this kind should be made. Under the conditions of the experiments $\mathrm{A}, \mathrm{B}$, and $\mathrm{C}$ there are distinct indications that the better toxic paints II, IV, and I are less toxic to marine algæ than to marine animals, but in order to confirm this indication it will be necessary to know whether light itself affects the toxicity of the paints. 
In this respect a chemical analysis of painted surfaces exposed contemporaneously in strongly lighted and diffusely lighted, but otherwise equivalent, situations respectively would probably yield significant information.

\section{Experiment $D$.}

$\checkmark$ Shells of the scallop, Pecten maximus, were painted with a variety of substances, strung on tarred rope, and secured to the bottom of the outside of the raft in Cawsand Bay.

Each of the substances (I to VI and VIII, see p. 376) being tested was painted on to a variable number, about ten, scallop shells, which

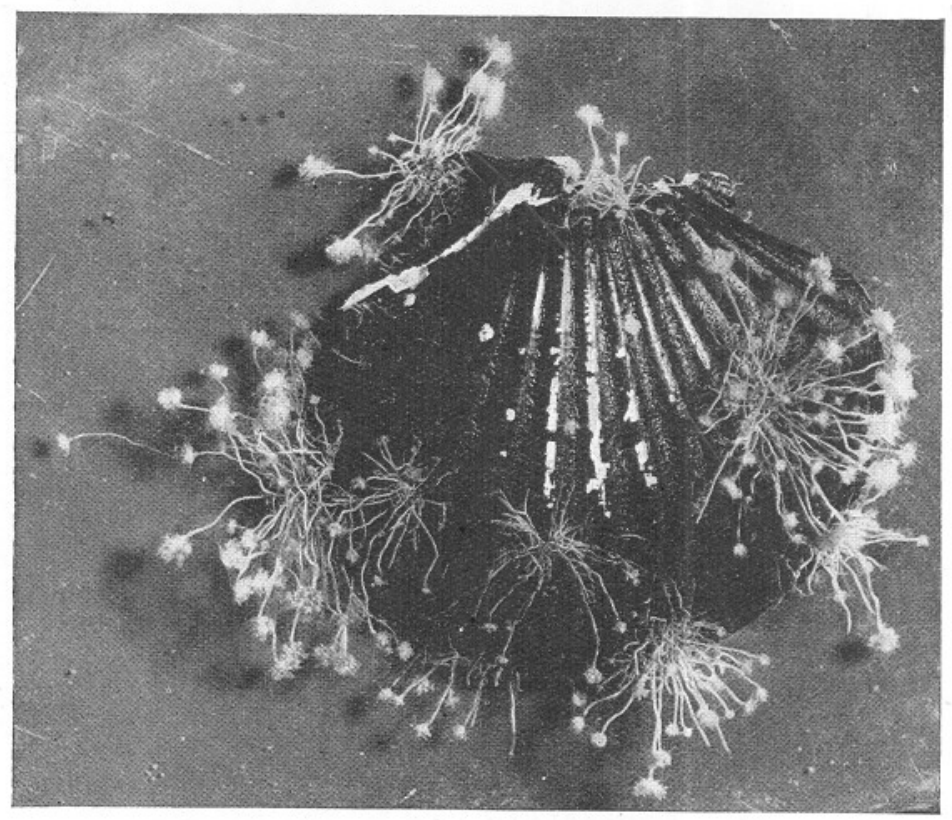

FIG. 8.- Photo of scallop shell from Experiment $D_{1}$, Cawsand Bay raft, painted with No. III substance (Black) showing the growth of Tubularia larynx on September 30th, 1919, after 6 weeks' exposure in the sea. ( $\times$ ca. $\left.\frac{3}{5}.\right)$ (Photo by D. P. Wilson.)

Compare Fig. 2, p. 381, and Fig. 5, p. 385. The shell was broken at one corner of the hinge to permit entry into a bottle for preservation. The shell is viewed from the rough outer surface and now shows signs of rubbing on the radiating ridges

were marked by a boring in a particular place for identification in the manner shown in Fig. 6, p. 385. The painted shells with clean control shells were put out on August 18th, 1919, and examined on September 30th, 1919, October 9th, 1920, and brought in and preserved October 23rd, 1920. 
The following note was written at the time the shells were put out, and as it is of importance in interpreting the results obtained it is given as written :-

"Two good coats of the paints were given to each shell. Unfortunately, some shells of all paints showed signs of rubbing on the smooth surface when the shells were put out. This was due to the necessity of carrying the shells to the wharf in baskets, during which time the jolting rubbed small patches of paint off the smooth surface of the shells. No case was seen of the paint on the rougher surface being broken. It is, therefore, obvious that paints of this kind chip or rub off very readily on a smooth surface, a fact of importance to be remembered in working with it, and drawing deductions from experiments. On recording subsequent growth on these shells, it is therefore necessary to take into account the condition of the paint at the time an observation is made. These rubbed shells may give valuable information regarding the arrest (or otherwise) of growths by paint if the rubbed areas permit growth and the paint composition inhibits such."

It will be shown later that marine growths were frequently observed on areas of shells denuded of paint, and confined to such areas by the inhibiting (i.e. poisoning) action of the adjacent painted area. Moreover, a painted shell might give an erroneous indication of permitting growth if denuded areas occur and fail to be observed ; and indeed in all experiments of this kind such a possibility must be constantly borne in mind.

The growth observed on these shells is shown in Table IV below and in Table V, p. 390, and Figs. 7, p. 387, and 8, p. 388.

It is noteworthy that some of the suspended shells in this experiment grew Laminaria, and were doubtless exposed to dim light.

\section{TABle IV. Experiment $D_{1}$.}

Reports on Growths on Treated Shells suspended outside the bottom of the Raft in Cawsand Bay on August 18th, 1919.

Designation and colour of surface.

I. Reddish brown, A-F

II. Green, $\mathrm{A}-\mathrm{F}$

III. Black, A-C

IV. Reddish brown, A-F

V. Black-bronze, A-C

VI. Reddish brown, A-F

VII. Greyish white untreated

VIII. Red, A-C

\section{Growth observed on \\ Sept. 30th, 1919 \\ (exposed 6 weeks).}

None, except small Tubularia at edges of one shell

None

Large growth of Tubularia and some Pomatoceros

None

Not observed. See Table VI, p. 392

None, except a little Tubularia on edge of one shell

Large growth of Tubularia on shells at one end of raft, very little growth at the other end

Fair growth of Tubularia
Growth observed on Oct. 9th, 1920 (exposed c. 14 months).

All

shells

except

No. II, green, with more or less growth similar to that on the boards in Experiment A (see Table I, Oct. 9th, 1920 , p. 382) 


\section{Table V. Experiment $\mathrm{D}_{1}$.}

\section{Report on Growths and condition of the Paint on Treated Shells} Suspended outside the bottom of the Cawsand Bay Raft on October 23RD, 1920, when the Shells Were BRought to the Laboratory and Examined and Preserved. (See Fig. 9, p. 393 and Fig. 10, p. 395.)

\section{Designation and colour of the surface and the number of shells. \\ Condition of the paint on the (a) smooth and (b) rough outside sur- face of the shells.}

I

Reddish brown A-F 7 shells.

II

Green

A-F

6 shells. (b) Rough outside surface. Almost all washed off except in the hollows.

(a) Smooth inside surface. Almost all washed off.

(a) Smooth inside surface. Nearly all washed off in all but one, which is still half-covered with paint. (b) Rough outside surface. The paint is about half washed off on the crests, but entire in the hollows on all shells but one, which is still covered by paint.

(a) Smooth inside surface. Washing off all more or less.

(b) Rough outside surface. None of the paint washed off.
Growth on the shells on

(a) smooth (inside) and

(b) rough (outside) surface.

(a) Almost all covered with Tubularia and other hydroids.

Some Balanus, Pomatoceros, Anomia, much Diplosoma, Ciona $(9 \cdot 5 \mathrm{~cm}$. contracted).

(b) Organisms overgrowing paint in parts, but restricted in some, but not in others, by the paint.

Some Balanus, Pomatoceros, many Anomia, much Diplosoma and extensive growth of Tubularia and other hydroids.

(a) Practically no growth on the paint. Diplosoma and Pomatoceros are overgrowing the paint a little in parts, but on the whole the growth of Diplosoma is obviously still limited to the area of clean (i.e. denuded) shell, and shows little inclination to extend over the paint.

Some Balanus, Anomia, Umbonula, Mytilus, as well as Diplosoma and Pomatoceros on the clean parts, and also Tubularia and other hydroids.

(b) Growth nil.

(a) Covered with an abundant growth.

Some Ciona up to $12 \mathrm{~cm}$. (con.), some Ascidiella up to $7.5 \mathrm{~cm}$. (con.). Actinoloba (greeny brown) $6 \mathrm{~cm}$. at base (con.) with column $3 \mathrm{~cm}$. high (con.).

Some Anomia, Pomatoceros, Hydroides, Serpula, Diplosoma, Umbonula, Tubularia and other hydroids, many small Sycon on Ascidiella, large Balanus and many small tubicolous Sabellid worms.

(b) Growths entirely covered 3 shells and almost covered the remaining 5 .

Some Anomia, Pomatoceros, Hydroides, Umbonula, Diplosoma, many colonies of hydroids and also the seaweed Laminaria, and a red seaweed. 
Designation and colour of the surface and the number of shells. IV

Reddish brown A-F 6 shells

Black-bronze

A-C

5 shells
Condition of the paint on the (a) smooth and (b) rough outside surface of the shells.

(a) Smooth inside surface. More than half the paint is washed off 5 shells; one with five-sixths of the paint still adhering.

(b) Rough outside surface. The paint is almost entire on 5 shells.

(a) Smooth inside surface. A very little washed off some, more than half off others.

(b) Rough outside surface. Three shells with paint entire but washed off one, and probably rubbing off another.

VI

Reddish brown

A-F

7 shells (a) Smooth inside surface. Almost all washed off. (b) Rough outside surface. A fair amount of paint left on some, but little on other shells.
VII

Greyish white untreated

6 shells (a) Smooth inside surface. Untreated.

(b) Rough outside surface. Untreated.
Growth on the shells on

(a) smooth (inside) and

(b) rough (outside) surface.

(a) Some shells are covered with growth even where the paint has remained : in others Diplosoma shows restriction by the paint.

Much Diplosoma and Tubularia, 1 Anomia, 2 Hydroides, 2 Balanus and 2 Mytilus.

(b) Three shells (one covered still with paint) have no growth.

Tubularia only is present on one shell.

Diplosoma is overgrowing half to onethird of the two other shells, which have also 2 Balanus and one Sabellid polychæte.

(a) Mostly well-covered with growth of Serpula, Pomatoceros, Hydroides, Tubularia, and other hydroids, Anomia, Balanus, Membranipora, Diplosoma, and Bicellaria.

(b) The same as in (a) above with, in addition, Ascidiella and Umbonula.

(a) Covered with growth : comprising :Many Pomatoceros, some Hydroides, Anomia, Balanus, Ascidiella $7 \mathrm{~cm}$. (con.), Sabella (10-8-cm. tube), much Diplosoma, Tubularia, and other hydroids, Membranipora, small tubicolous Polychætes, Laminaria saccharina with roots growing around the edge.

(b) All shells practically covered with growth, which is obvious even over the paint.

About 20 plants of Laminaria saccharina on one shell, and 3 other shells with 1 to 5 plants: fronds up to $96 \mathrm{~cm}$. long by $15 \mathrm{~cm}$. wide.

Many Hydroides, few Pomatoceros, Balanus, and Anomia, much Tubularia and other hydroids, and Diplosoma overgrowing many shells. Mytilus up to $22 \mathrm{~mm}$. in length.

(a) Covered with growth.

Ascidiella up to $7 \mathrm{~cm}$. (con.) ; Ciona up to $6.5 \mathrm{~cm}$. (con.). Tubularia and other hydroids, many Anomia, Balanus 2 species, Umbonula, Pomatoceros, Sabella, and other tubicolous Polychætes, young Actinoloba (?), and seedlings of Laminaria.

(b) Covered with growth.

Ascidiella up to $6 \cdot 3 \mathrm{~cm}$. (con.), Balanus, Anomia, Pomatoceros, Tubularia, and other hydroids, Actinoloba $3 \times 4.5$ $\mathrm{cm}$. at base and column 1 to $1.5 \mathrm{~cm}$. high (con.), 12 small seedlings of Laminaria. 


\begin{abstract}
Designation and colour of the surface and the number of shells.

Condition of the paint on the (a) smooth and (b) rough outside surface of the shells.
\end{abstract}

VIII

Red

A-C

5 shells (a) Smooth inside surface. Almost all washed off.

(b) Rough outside surface. Almost all washed off.
Growth on the shells on

(a) smooth (inside) and

(b) rough (outside) surface.

(a) All covered with growth : 4 Ciona up to $11 \mathrm{~cm}$. long (con.); 3 Ascidiella up to $8 \mathrm{~cm}$., many Anomia, several Pomatoceros, much Tubularia, and other hydroid growth, 3 Balanus and one tubicolous Polychæte.

(b) All covered with growth: Laminaria saccharina frond $105 \mathrm{~cm}$. slightly broken $\times 14 \mathrm{~cm}$. wide.

Laminaria Digitata (?) $60 \mathrm{~cm}$. broken $\times 13 \mathrm{~cm}$. wide. Many Balanus, Anomia, Hydroides, some Pomatoceros, Serpula, and many colonies of Tubularia with other hydroids. (See Fig. 11, p. 397.)

\section{Experiment $D_{2}$.}

Shells of the scallop, Pecten maximus, were painted with a variety of substances and fixed to the outside of the bottom of the raft in Cawsand Bay on August 18th, 1919.

In addition to substances I to VI and VIII, black varnish, No. IX substance, p. 376, was also painted on to five shells in this experiment. These shells permitted growth in the same way as those strung under the raft (see Table V), except that the Nudibranch, Facelina drummondi, crawled on to and deposited spawn on the colonies of Tubularia larynx which were growing on some of the painted substances (as is shown in Table VI below) on September 30, 1919.

\section{TABle VI.}

Report on Growth and Conditions of Paint on Shells natled to the outside of the bottom of the Cawsand Bay Raft.

\begin{tabular}{|c|c|c|}
\hline I. Redd & $\begin{array}{l}\text { Growth } \\
\text { Sept. 30th, 1919* } \\
\text { (exposed } 6 \text { weeks). }\end{array}$ & $\begin{array}{c}\text { Growth } \\
\text { Oct. 9th, } 1920 \\
\text { (exposed c. } 14 \text { mths.). }\end{array}$ \\
\hline $\begin{array}{l}\text { A-F } \\
\text { II. Green, A-F } \\
\text { III. Black, A-C }\end{array}$ & $\begin{array}{l}\text { None } \\
\text { Large colonies of Tubularia and } \\
\text { Pomatoceros }\end{array}$ & $\begin{array}{l}\text { All shells except No. } \\
\text { II with more or less } \\
\text { growth similar to }\end{array}$ \\
\hline $\begin{array}{l}\text { IV. Reddish brown } \\
\text { A-F }\end{array}$ & None & on Oct. 9th, 1920, \\
\hline V. Black-bronze, $\mathrm{A}-\mathrm{C}$ & $\begin{array}{l}\text { Large colonies of Tubularia with } \\
\text { Nudibranch spawn and two shells } \\
\text { with Pomatoceros }\end{array}$ & $\begin{array}{l}\text { in Experiment A. } \\
\text { (See Table I, p. } \\
\text { 382.) }\end{array}$ \\
\hline $\begin{array}{l}\text { VI. Reddish brown } \\
\mathrm{A}-\mathrm{F}\end{array}$ & None & o. II has no growth \\
\hline $\begin{array}{c}\text { VII. Greyish white } \\
\text { untreated }\end{array}$ & $\begin{array}{l}\text { Large colonies of Tubularia with } \\
\text { Nudibranch spawn and Poma- } \\
\text { toceros }\end{array}$ & $\begin{array}{l}\text { No. IV has only slignt } \\
\text { growth. } \\
\text { No. IX has large } \\
\text { Ciona. }\end{array}$ \\
\hline III. $\operatorname{Re}$ & $\begin{array}{l}\text { Large colonies of Tubularia and } \\
\text { Nudibranch spawn }\end{array}$ & \\
\hline
\end{tabular}

* Tubularia observed growing on the heads of the iron nails used for the experiment. 

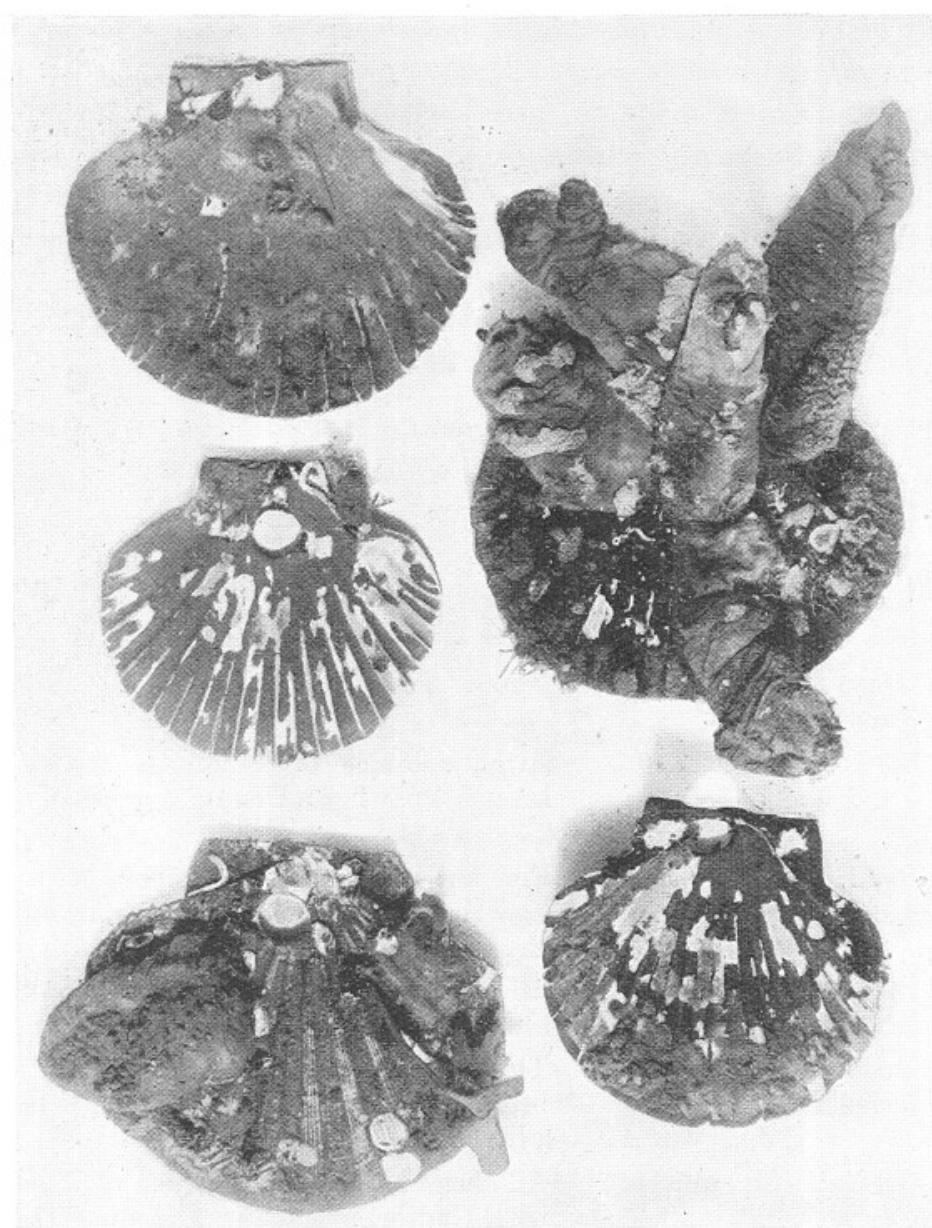

FIG. 9.-Photo of shells from Experiment $D_{1}$, Cawsand Bay Raft, October 9th, 1920 ; exposed to the sea on August 18th, 1919. See Table V, p. 390. ( $\times$ ca. $\frac{2}{5}$.) (Photo by D. P. Wilson.)

I Red: with much Diplosoma and also Balanus and Hydroides, Anomia and a little Tubularia. Very little paint is left on this, the smoother, surface of the shell.

II Dark green: with Diplosoma and Hydroides growing on the hinge-line, but no growth elsewhere. The paint is shown to be washing off badly : smooth surface view of shell.

III Black : with Ciona and Diplosoma mainly, but also with Hydroides, Anomia, and Tubularia : smooth surface view of shell.

IV Red : with Diplosoma mainly and mostly confined to areas denuded of paint. The paint is washing off badly from the smoother surface of the shell as shown.

VII An untreated shell with Ascidiella, Anomia, Pomatoceros, Balanus, and Laminaria: the rougher surface of the shell is shown. 


\section{Experiment E.}

Shells of Pecten maximus treated and strung on tarred ropes or nailed inside the raft at Cawsand Bay on August 18th, 1919.

Observations were made on these shells at various times, and growth and resistance to growth found to occur in the order shown in experiments A to D.

One full report of the hanging shells was made on October 22nd, 1919, as in Table VII.

\section{TABLE VII.}

Report on Shells strung on Tarred Rope inside the middle compartment of the Cawsand Bay Raft.

\footnotetext{
Growth on October 22nd, 1919

(exposed c. 9 weeks).

I Reddish brown; A-F None. 5 to 8 shells

II Green; A-F None : 2 shells peeling. 8 shells

III Black; A-C 5 to 8 shells

IV Reddish brown; A-F 8 shells

V Black-bronze; A-C 5 to 8 shells

Large colonies of Tubularia with Nudibranch spawn and some Pomatoceros on all shells.

Five shells no growth : 2 shells with small growth and one with fair growth of Tubularia.

All shells with large colonies of Tubularia and some Pomatoceros.

VI Reddish brown; A-F 5 shells

Three shells with only spawn of the Nudibranch Facelina drummondi : 2 shells with a little Tubularia.

VII Greyish white untreated 5 to 8 shells

All shells have large colonies of Tubularia with Nudibranch spawn and some Pomatoceros.

VIII Red ; A-C 8 shells

Seven shells with Tubularia and one clean : the paint is peeling off 3 shells.

\section{History of the General Growth on the Raft in Cawsand Bay.}

The history of the growth observed on and in the raft from time to time is important in relation to the growth found on the adjacent treated and untreated shells, and is best shown in a condensed form as follows in Table VIII.
} 


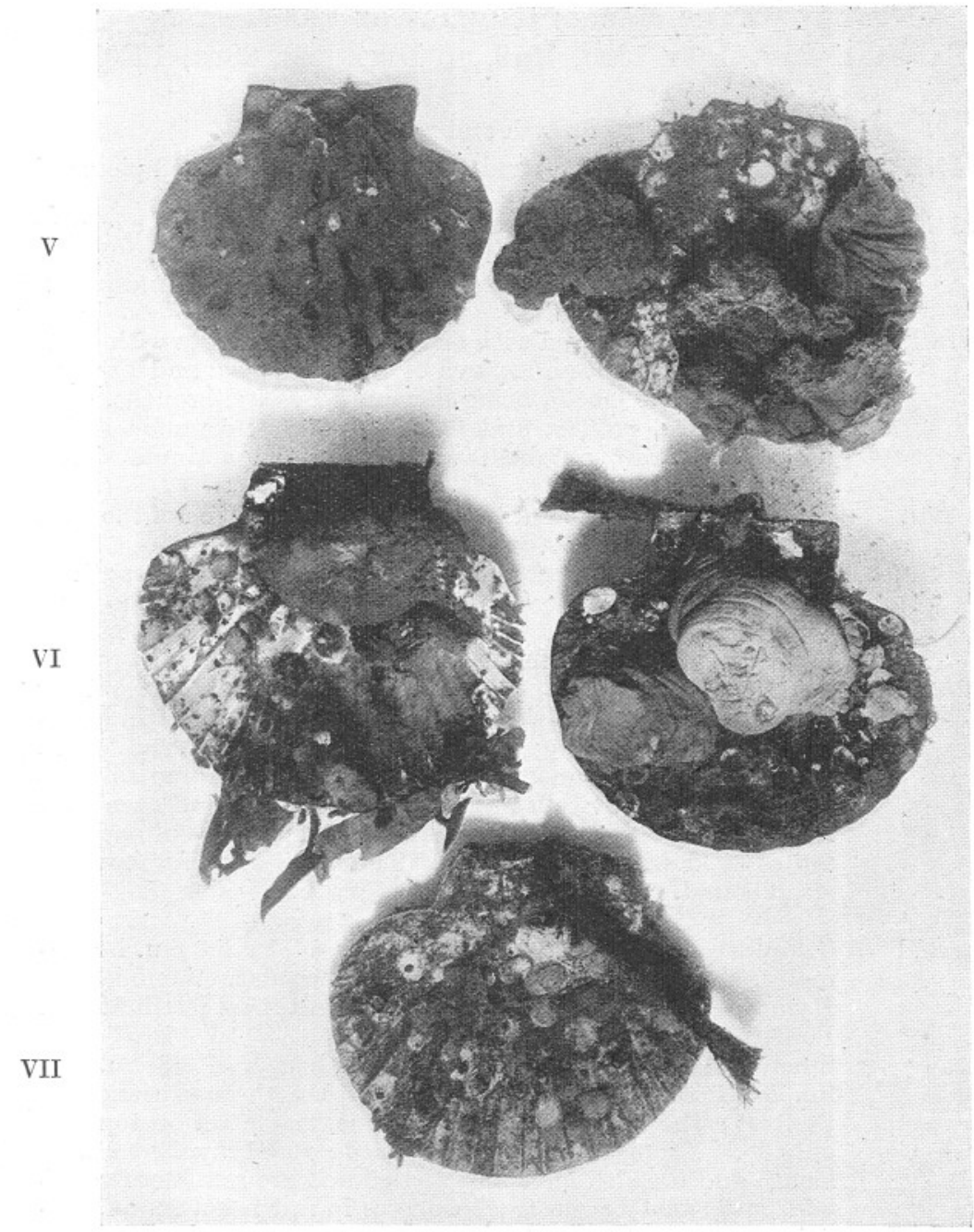

FIG. 10.-Photo of shells from Experiment $D_{1}$, Cawsand Bay Raft, October 9th, 1920. See Table V, p. 390. ( $\times$ ca. $\frac{2}{5}$.) (Photo by D. P. Wilson.)

V Black. Outer (rough) surface of a convex valve with the paint still almost entire, but with Balanus, Anomia, Pomatoceros all becoming overgrown with Diplosoma.

VI Red : view of inner (smooth) surface of a convex valve almost denuded of paint, with a large Ascidiella, Dasychone, 15 individuals of Anomia, some Diplosoma, and several roots of Laminaria.

VIII Red : smooth surface of a flat valve now denuded of paint: with four large Ciona, 13 Anomia, one Balanus, some Diplosoma, and Tubularia.

III Black : inner surface (smooth) of a convex valve; with one large and one small Actinoloba, one large Ciona, several Hydroides, and Balanus, one Pomatoceros, one Anomia, and a little Diplosoma and Tubularia. The paint is almost entire and is being telescoped on the shells of the Balanus.

VII Untreated: inner smooth surface view : with Balanus, Pomatoceros, numerous Anomia, all becoming overgrown with Diplosoma, some Botryllus, Hydroids and a root of Laminaria. 


\section{TABLE VIII.}

History of the Marine Growths on the Raft in Cawsand Bay, July 16th, 1919, to December 28th, 1920.

1919. July 16 th

Aug. 7th

Aug. 18th

Sept. 30 th

Oct. 10 th†

Oct. 28th

1920.

March 2nd

Oct. 9th
Growth and remarks.

Raft put in the sea, tarred and dried, with attached pieces of untreated wood.

Obelia with spawn of Tergipes and Galvina exigua covering the bottom of the raft. Veligers already in the spawn. Teredo in borings about $\frac{1}{2}$ inch long (perforated zinc crab-and-prawn cage put inside the raft).

Bottom of raft covered with dense growth of Obelia with great abundance of adult and spawn of Galvina exigua and Tergipes despectus. The Obelia being devoured by Nudibranchs.

Galvina picta, pallida, and farrani types all common and a little Tubularia* obtained which extruded actinula larvæ overnight.

Large colonies of Tubularia common on the bottom of the raft, with abundant Pomatoceros and Nudibranchs.

Facelina drummondi common on the raft up to a length of $3.6 \mathrm{~cm}$. extended : numerous masses of its spawn on the large colonies of Tubularia, which at one end of the raft mostly have the "heads" eaten off.

The prawn Leander (=Palæmon) serratus has settled in numbers and grown in situ to a length of $4.3 \mathrm{~cm}$. inside the perforated cage along with young Cancer pagurus which have a carapace diameter of 7 to $10 \mathrm{~mm}$. Two fine colonies of Bugula (with ovicells and ova) in the perforated cage with Anomia, Tubularia, and Nudibranchs. The sides of the raft are covered with young Ciona. Tubularia and Nudibranchs still abound.

Colonies of Membranipora sub-circular 4.5 by $5 \cdot 0 \mathrm{~cm}$. in diameter, and of Umbonula $2 \cdot 2 \mathrm{~cm}$. sub-circular. Anomia and Hydroides mature, and gave successful artificial fertilisations. Pomatoceros mature.

Small Antedon rosacea with arms to a length of $3.8 \mathrm{~cm}$. and limpets, Patella vulgata, 8 to $13 \mathrm{~mm}$. in length have settled on the raft ; the former below and inside, the latter on top and outside. Young Pecten opercularis up to 31 by $29 \mathrm{~mm}$. in length and breadth have also settled and are sexually mature and gave good brown trochospheres in fair numbers on artificial fertilisation (a cross fertilisation was made in this case, $P$. opercularis is hermaphrodite). Sabella pavonina with tubes up to $17 \mathrm{~cm}$. long by $4.5 \mathrm{~mm}$. wide fairly common, and abundant adult Sycon and some Leucandra. The top of the raft is covered with Enteromorpha and some Ulva. (Put out on the raft fresh clean pieces of wood.)

\footnotetext{
* Tubularia was specially searched for on August 7th, and not seen : it is probable, therefore, that these small colonies grew in about eleven days.

$\dagger$ On this day a remarkable Galvina was taken: it had the characteristics of all three types-picta, pallida, farrani-in one individual. The lateral cerata were orange tipped; the median, brown tipped, and the dorsal part of the body was splashed with reddish brown patches as is the case in picta.
} 


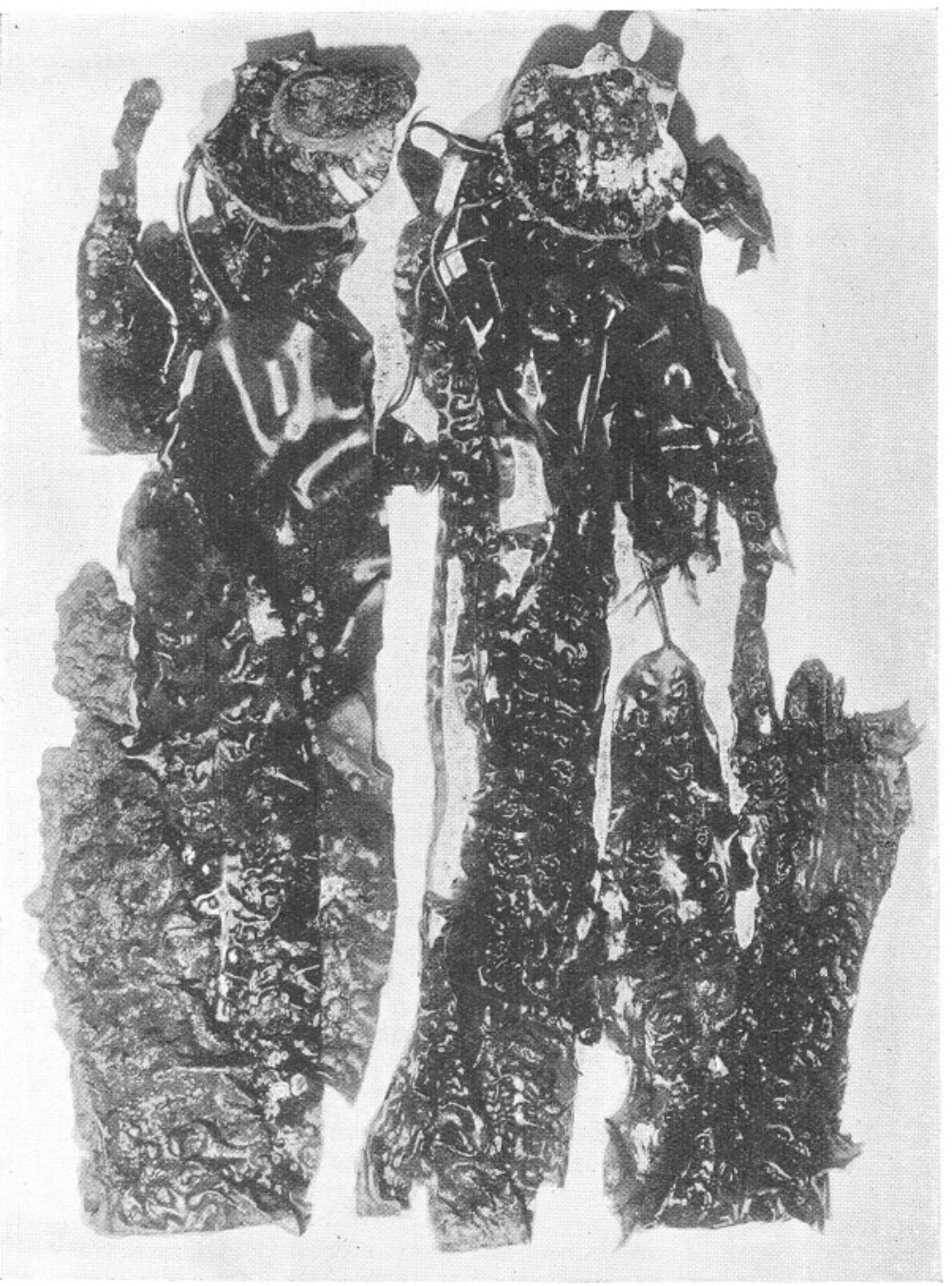

FIG. 11.-Two shells from Experiment $D_{1}$, Cawsand Bay Raft, October 9th, 1920, with many large Laminaria fronds. ( $\times$ ca. $\frac{1}{5}$.) (Photo by D. P. Wilson.)

The convex shell on the left was painted with No. VIII substance, red, which was almost all washed away from the inner (smooth) surface shown. On this shell, besides the Laminaria fronds, which have been folded, are one large Ascidiella, 13 Anomia, Pomatoceros, Hydroides, and Tubularia.

The convex shell on the right was painted with No. V substance, red, which remains only in traces on the smooth inner surface shown. Besides Laminaria, there are shown in this view of the shell, 4 large Balanus, 23 Anomia, one Sycon coronatum, and much Diplosoma. The larger fronds of Laminaria are folded along about half their length, and are themselves covered with numerous colonies of Diplosoma, some Botryllus and Obelia. 
1920.

Oct. $23 \mathrm{rd}$

\section{Growth and remarks.}

The raft is covered with Laminaria, and red weeds on the sides and green weeds on the top, but underneath and inside with animal growths. Samples of the growths were brought in to the Laboratory and examined as follows :-

\begin{tabular}{|c|c|c|c|c|c|}
\hline \multicolumn{2}{|c|}{ Species. } & $\begin{array}{l}\text { Length } \\
\text { of plant } \\
\text { in } \mathrm{cm} \text {. }\end{array}$ & $\begin{array}{l}\text { Width of } \\
\text { frond } \\
\text { in } \mathrm{cm} .\end{array}$ & $\begin{array}{l}\text { Width of } \\
\text { stipes } \\
\text { in } \mathrm{mm} \text {. }\end{array}$ & Remarks. \\
\hline \multicolumn{2}{|c|}{ Laminaria saccharina } & 95 & 14 & 4 & Frond frayed at end. \\
\hline , & , & 102 & 12 & 4 & $" \quad, \quad, \quad$ a little. \\
\hline ", & , & 88 & 10 & $3 \cdot 5$ & , $, \quad, \quad$, \\
\hline " & , & 110 & 16 & 4 to 6 & $\begin{array}{l}\text { Broken : possibly twice as } \\
\text { long in uninjured con- } \\
\text { dition. }\end{array}$ \\
\hline$"$ & , & 143 & $15 \cdot 6$ & $8 \cdot 5$ & Slightly broken. \\
\hline ,' & ," young & $12 \cdot 5$ & $2 \cdot 6$ to $2 \cdot 8$ & 2 to 3 & Entire. \\
\hline L. digitata & , young & $\begin{array}{l}60 \\
83\end{array}$ & $\begin{array}{l}4 \cdot 6 \\
32\end{array}$ & $\begin{array}{c}4 \text { to } 6 \\
8\end{array}$ & $\begin{array}{l}\text { Entire. } \\
\text { Broken and covered with } \\
\text { Membranipora on both } \\
\text { sides. }\end{array}$ \\
\hline L. digitata sti & ipes and root & 16 & - & - & \\
\hline , & & 88 & 21 & $8 \cdot 5$ & Frond broken. \\
\hline ", & & 59 & - & $6 \cdot 5$ & $\begin{array}{l}\text { Frond broken with a colony } \\
\text { of } M . \quad \text { membranacea } \\
25 \times 5 \cdot 5 \quad \mathrm{~cm} . \quad \text { sub-rect- } \\
\text { angular. }\end{array}$ \\
\hline , & ung & $\begin{array}{l}23 \\
29\end{array}$ & - & $\begin{array}{l}3 \cdot 8 \\
5 \cdot 5\end{array}$ & Frond entire. \\
\hline
\end{tabular}

Helcion pellucida $6.8 \mathrm{~mm}$. long was taken from the stipes of Laminaria and Mytilus edulis up to $24 \mathrm{~mm}$. long were common among the roots of the same plants. There was a heavy growth of animals inside and at the bottom outside, the dominant forms being Pomatoceros, Anomia, Hydroides, Ciona, Ascidiella, Diplosoma, Balanus, Sycon, Podoceros (=Jassa), Tubularia, and other hydroids with various Nudibranchs and various Polyzoans. Among the less abundant and occasional forms were Sabella and other smaller Sabellids, Serpula, Pecten, Patella, Mytilus, Helcion, Antedon, Leucandra, Actinoloba juv., Leander, Cancer juv., Porcellana, and Carcinus juv.

1920.

Nov. 11th On this day the mooring chain and shackles were overhauled and made secure, as it was probable that it would be many months before observations on these experiments could be resumed owing to the investigator being called away on urgent work in connexion with oyster mortality (4).

Dec. 28th The raft broke adrift in a strong gale some time between the nights of December 25th and 27th, and was washed ashore; it was badly smashed and rubbed. The whole of the top was missing and also many battens from the sides as well as all the experimental material. A reward was vainly offered for the discovery and return, especially of the experimental boards and the lid (for Patella). Apparently one of the main vertical bolts had broken in the wood, and its fellow had been broken off where it emerged from the wood. For this reason a stouter iron basic frame was introduced into future designs.

The battens on the bottom and sides were bored to a great extent by Teredo. Most of the borings were unoccupied and contained putrefying matter. Probably most of those belonged 
to infections in previous seasons. A few borings of living animals were however found up to a length of $25 \mathrm{~cm}$. with a mean diameter of about $1 \mathrm{~cm}$. and a diameter of $12 \mathrm{~mm}$. at the inner boring end. A few Actinoloba, Mytilus, Balanus, and Sycon remained on the raft. The Actinoloba are of interest as follows :-

$\begin{array}{lcccc}\text { Actinoloba dianthus. } & \begin{array}{c}\text { of flower } \\ \text { in cm. }\end{array} & \begin{array}{c}\text { of column } \\ \text { in cm. }\end{array} & \begin{array}{c}\text { of base } \\ \text { in cm. }\end{array} & \text { of column. } \\ \text { (a) Pink and extended } & 9 \cdot 5 & 4 \cdot 3 & 5 \cdot 5 & - \\ \text { (b) White contracted } & - & 3 \cdot 8 & 3 \cdot 2 & 2 \cdot 7 \\ \text { (c) White partly extended } & - & 5 \cdot 0 & 5 \cdot 0 & 7 \cdot 0\end{array}$

\section{The Exposure of the Raft and Experimental Material to "INFECTION."}

The history of the growths on the raft and the experimental material in Cawsand Bay along with a knowledge of the breeding periods of the dominant organisms concerned render it possible to follow the exposure of the raft and experimental material to infection by potential growths.

When the raft was moored in the sea in Cawsand Bay it immediately became infected with Obelia planulæ and spores of Enteromorpha. Almost simultaneously Nudibranch post-veligers (of Tergipes and Galvina) attacked the young Obelia and established themselves. About August 7th, 1919, Tubularia larynx actinulæ settled on the raft and established a recurring source of infection which was maintained until the close of the experiment. Thus when the experimental material was put in the sea on August 18th, 1919, it became subject at once to infection by Tubularia from at least a local source. The larval form of Tubularia, the actinula, is highly adhesive; and it will adhere firmly to a clean glass pipette or dish, or to the frond of Laminaria, and very easily to rougher surfaces than these. This larva is moreover virtually a passive floating organism, it is devoid of light-sensitive organs, and is thus one of the most efficient larvæ for testing the value of a poisonous surface. Indeed, both the efficiency of the poisonous paints and of the larva as well as that of the infection is demonstrated in experiments $\mathrm{A}$ to $\mathrm{E}$ by the fact that this larva established itself on all the non-poisonous surfaces and on small rubbed areas of the shells painted with proven poisonous paints.

During August numerous Pomatoceros and Diplosoma larvæ settled on the raft and on the shells treated with non-toxic paints. Diplosoma, like Tubularia, produces larvæ, in this case, however, tadpoles, which are adhesive and settle at once on objects adhered to. It is probable that the tadpole of Diplosoma is only light-sensitive for a short space of time, if it is at all light-sensitive. Diplosoma can attain maturity in six weeks and breeds during most of the year, so that once this organism is 
established on a locality it can reinfect the locality over the greater part of the year, excepting the winter period.

In this month, August, and in September the larvæ of Ascidiella and Ciona settled in numbers on the raft along with the larvæ of Balanus, Teredo, Sponges, Polyzoa, and Polychætes, and the spores of many seaweeds.

There is little doubt that infection from all the sources would continue during October and at least part of November (2).

After November general infection would diminish until about MarchApril, when a fresh infection of Balanids and Hydroids especially would begin, and from April-May onwards all the dominant forms mentioned above would continue to infect the raft from outside and some from local sources during the ensuing summer. There can be no doubt, therefore, that the experimental material on the raft was well tested by a succession of larvæ during the greater part of the time that the raft was in the sea, as is shown by the general growth on the raft itself.

\section{Results of Experiments $A$ to $E$.}

Under the conditions of these experiments, which are in some respects severe (but see general discussion on p. 428), it is seen that only the substances II, IV, and I have an effective anti-fouling action. During the period of these experiments, i.e. about fourteen months (August to October), so long as these paints remained on the experimental material, animal growth was almost entirely inhibited by these three substances, but where they were exposed to light growth occurred in about six months. The substances II, IV, and I adhered to the test material approximately in this experiment in the order of their value for inhibiting animal growths, so that it is probable that the paints were eroded before losing their toxic value.

It is thus manifest that a fundamental property of an anti-fouling paint is the capacity for resisting rapid erosion or dissolution in the sea. In these tests all the experimental material was subject to the constant movement produced on the raft by wind and waves.

The anti-corrosive paints III and V remained in the best condition on October 23rd, 1920, and may therefore be said to fulfil a preservative function (for non-wooden structures) satisfactorily for the period and conditions of the experiments.

Red oxide of iron, No. VIII substance, which is commonly used as an anti-corrosive paint on iron buoys, was found to be useless as an antifouler ; and since it became eroded almost entirely in fourteen months, or less, must be deemed less valuable as an anti-corrosive paint than substances III and V for the conditions of these experiments which are similar to those affecting buoys. 
SERIES II. GREAT WESTERN RAILWAY, WEST WHARF, MILLBAY DOCKS, PLYMOUTH.

\section{Experiment $F$.}

On 3-feet test-boards fixed at low-water mark.

In this experiment eleven boards 3 feet by 4 inches by 1 inch were treated with substances I to XII (see p. 376)-excepting No. VII board, which was again untreated-and put in the sea on August 27th, 1919. These boards were affixed vertically to old Jarra piles at low-water mark at the West Wharf, Millbay Docks, Plymouth. The lower ends of the boards (except No. II, which was slightly higher than the others) were fixed about 6 inches below ordinary spring-tide level so that about 2 feet 6 inches of the board would be above the mean spring-tide level. Four additional untreated pieces of wood were put out as additional controls of growth on August 28th, 1919, and five more pieces of untreated wood were put out on February 23rd, 1920, alongside the experimentally treated boards in Bays 3 to 7 inclusive, i.e. alongside boards VIII and XII, V, IV, IX, and XI. These untreated boards were soon lost, but they served the purpose of demonstrating growth on untreated surfaces alongside the treated surfaces. Substances VIII, red oxide of iron, and XII, aluminium paint, were painted on to one board on vertical halves ( 36 by 2 by 1 inches). The 3 -feet boards were of red pine, except No. VII, which was of elm, the additional pieces of wood being ordinary deal.

Numerous visits were made to the West Wharf in studies on the lowwater fauna, and the records made on ten inspections of the experimental material from September 25th, 1919, to March 7th, 1923, are given in Table IX, pp. 402-3. In this table is shown the history of the growths which occurred on each of the boards and the condition of the paint. The growths on the experimental substances and on untreated wood (VII) can be readily and easily compared at successive periods of the experiment. The condition of the surviving boards at the end of the experiment is shown in Figs. 12, p. 404, 13 and 14, pp. 405 and 408.

\section{Summary of Results from Experiment $F$.}

The board with the green poisonous paint, No. II, remained almost intact during the course of the experiment, i.e. about $3 \frac{1}{2}$ years. All the remaining surviving boards were badly eaten by gribble at the close of the experiment, and of the two boards which were lost, one (No. XI) was nearly eaten away on December 16th, 1921, but the other (No. IX) on this latter date was in good condition and might have remained so for a longer period.

Growth began first on boards V and IX. It is a noticeable fact that 
Table IX. Experiment F.

Reports on Growths (and Condition of Painted Substance) on 3-Feet Test-Boards (Treated and Untreated) put out on August 27th, 1919, at Low Water Spring-Tide Level at the West Wharf, Millbay Docks, Plymouth.

No., colour, and of paint and position o

Reddish brown (exposed $c$.

Dec. 8,1919 exposed $c$.

Feb. 7, 1920

May 19,1920
$($ exposed $c$. $\begin{array}{rr}\text { (exposed } c . & \text { (exposed } c . \\ 6 \text { months). } & 9 \text { months). }\end{array}$ No growth No growth, paint $\mathrm{A}-\mathrm{F}$
$10 \mathrm{Bay}$ good

No growth, but Nog
an untreated good
board alongside

board alongside

has Diploso

Aug. 16, 1920 (exposed $c$.

April 22, 1921 (exposed $c$.

Dec. 16,1921 (exposed $c$.

March 17, 1922 exposed $c$. slight growth of a slight growth on A little growth Not reported on ew barnacles : paint bottom of board; only on the on the lead label bottom of alongside covered no gribble seen riddled with gribble) No growth $\underset{\mathrm{A}-\mathrm{F}}{\text { Green }}$

11 Bay, outer

III No growth

$\underset{\mathrm{A}-\mathrm{C}}{\mathrm{Black}}$ 11 Bay, inner

IV
Reddish brown No growth A-F No growth, paint No growth good No growth, paint
good

No growth, paint
hard and in condition

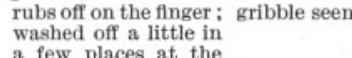

ot reported on

No growth,
paint good

No growth, but Good has spawn

Good
bottom

rowth,
at
paint

very good and

hard

Extensive growth

Clean board

ed with growth

and riddled with

gribble)

A few barnacles Slight growth of a few Slight growth of A good growth Not reported on on the bottom of barnacles: a little hydroids, Balanus now present

the board: Daint Diplosoma and and Sycon

(Untreated board 1920. Botryllus on

alongside cover- lead label, and a few

ed with growth colonies of Botry
and riddled with on the board all over, no gribble

Growth begun, Good growth, Good growth of Covered

with Covered with growth Extensive growth: With a good Now eaten avay

small colonies of fewer Diplosoma; Diplosoma and growth of small of Di plos o ma, board eaten by grown, fearly to a smatl remna

A-C
4 Bay hydroid growth, the board paint good losoma and Bugula. Untreated inch at the sides gribble Obelia: paint board alongside

yery good riddled by gribble

(Untreated board

alongside as
March 7, 1923 (exposed $c$.

$42 \frac{1}{2}$ months). Good piece of board away by gribble : bored by Teredo. mostly eaten also by gribble, but the ittle paint left is overgrown by Botganisms. See flo 13 Slight growth only in places, and solated parts and at edges.
brought in $\begin{gathered}\text { Board } \\ \text { still }\end{gathered}$ covered with some paint on most o surface, See fig, 13 Good piece of boarc left, but covered by by growth. Board
brought in. See flg. $13, \mathrm{p}, 405$

Good piece of board left, but covered brought in, paint still covering nart of surface. See flg. 13, p. 405 
No growth Not examined, Nogrowth, paint G row th of Covered with growth Heavy growth of Now partly Not reported on,

tide too high and apparently Ascidians washing off and very ately eaten by a nd covered 1922, found to gribble on the face with growth be nearly eaten as well as at edges away by gribble

Good growth on All untreated Covered with Covered with growth Nearly eaten away
two boards,three boards with growth, and and riddled with and brought back to

See fig. $14,1,407$

VII untreated 14 Bay 8 Bay outer

3 to 7 Bays

No growth

\section{VIII}

$\mathrm{A}-\mathrm{C}$

$\underset{\text { Black }}{\text { IX }}$

$\mathrm{A}-\mathrm{C}$ ?

6 Bay

$\underset{\substack{\text { Black } \\ \text { A-C }}}{\mathrm{X}}$

$9 \mathrm{Bay}$

$\underset{\text { Green }}{\mathrm{XI}}$

No growth

7 Bay

XII

$3 \mathrm{Bay}$
Sil very gre

No growth

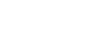

sp.

No

No growth, paint No growth visible Co
now washing off

$\begin{array}{lll}\text { boards not seen. Diplosoma and board becoming gribble } & \text { laboratory. Two } \\ \text { Diplosoma, Bot- Botryllus and riddled with } & \text { additional untreat- }\end{array}$

ryllus, Umbonula gribble, especi- gribble. Teredo
and hydroids ally on the probably also

ally on the probably also

bottom of the present

ed boards pre-

viously riddled with

gribble are now

having broken

away after being

with paint very soft

Covered with growth
of Diplosoma, Bot-

Extensive growth

$\begin{array}{ll}\text { and on July } 15 \text { had } & \\ \text { also some brown algæ }\end{array}$

Growth begun by Much Diplosoma Much growth of Good growth Covered with growth Extensive growth: Covered with Not reported on LOsT

a young colony on bottom of Diplosoma and covered with as on VIII and also slight attack by growth; not
of Halichondria board and some Botryllus on the spat of Balanus, medium Ascidiella gribble in one much eaten by

board and some Botryllus on the spat of Balanus,
Ascidians, paint bottom of the hydroids and

good

board Ascidiella : pain

gribble in one much eaten by

Slight growth, Growth of Dip- Covered with Covered with growth, Extensive growth: Covered with Not reported on

paint good losoma and growth and spat paint in good con- not attacked by growth, gribble

$\begin{array}{llll}\text { Botryllus } & \text { of Balanus at dition } & \text { gribble except in is beginning to } \\ & \text { higher level: } & \text { one top corner eat away the }\end{array}$

paint very good

eat away the

Most of the board till left, and pain half of outer and most of inner face. and brought in. See board No growth, paint No growth, Hali- Much spat of No paint left; Fair amount of Nearly eaten Not reported on fig. 13, p. 40 good, Halichon- chomition to balanus, but no Now

apparently un- board in places paint very good. (July

$\begin{array}{lll}\text { able to it } & \text { grow on to board alongside, put growth on bottom of } \\ \text { on to } & \text { put }\end{array}$

$$
\begin{aligned}
& \text { out Feb. 23, board) } \\
& \text { covered with } \\
& \text { growth and } \\
& \text { riddled with } \\
& \text { gribble) }
\end{aligned}
$$
$\begin{aligned} & \text { Nogrowth, paint } \\ & \text { cracking }\end{aligned}$
visible: prow th No growth visible Covered with Covered with growth Extensive growth: Nearly eaten Now eaten avay
spat of Balanus: hard gribble brought in

NOTES TO TABLE IX. EXPERIMENT F.

The Bays in which the boards were put out are reckoned from the south end of the West Wharf.
On December 16th, 1921, the examination of the boards was made in my absence by my assistant in this work, Mr. William Searle.

Paints VIII and XII were painted on the same board, half of the board on the long axis and $36 \times 2 \times 1$ inches being painted with red oxide and the corresponding half with aluminium paint.

"Gribble" is a seaman's term for both Limnoria lignorum and Chelura terebrans. Both these animals were taken from the experimental material, but Limnoria was by far the most abundant, and appears to live at a slightly higher level in the inter-tidal zone than Chelura.

As the boards were nailed on to and against Jarra piles, it was not possible to examine the back parts of the boards during the course of the experiments 


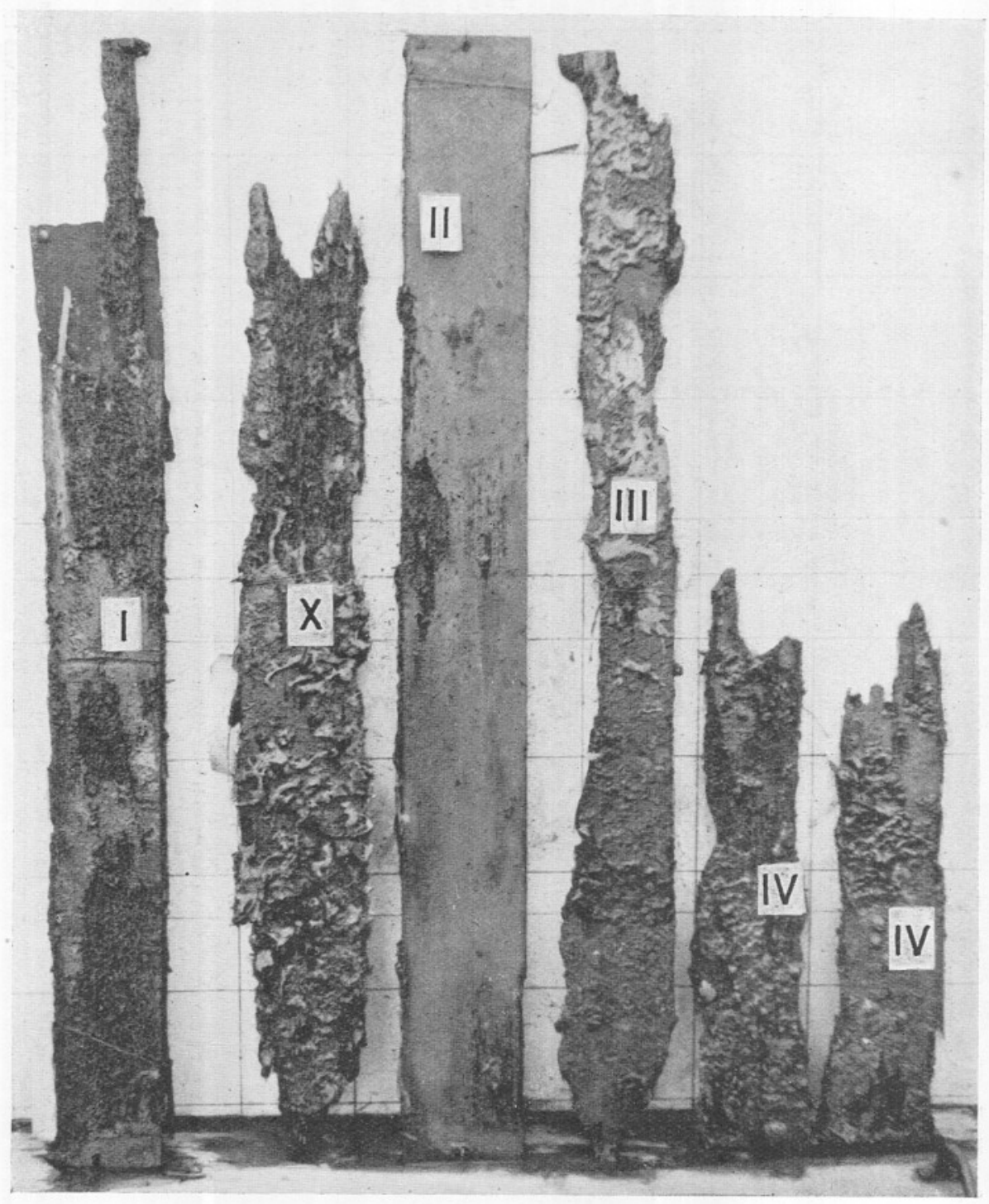

FIG. 12.-Photo of test-boards from Experiment F, Great Western Railway Wharf, Millbay Docks, Plymouth, with living growths on March 7 th, 1923, after $3 \frac{1}{2}$ years' exposure in the sea. ( $\times$ rs.) (Photo by A. J. Smith.) 


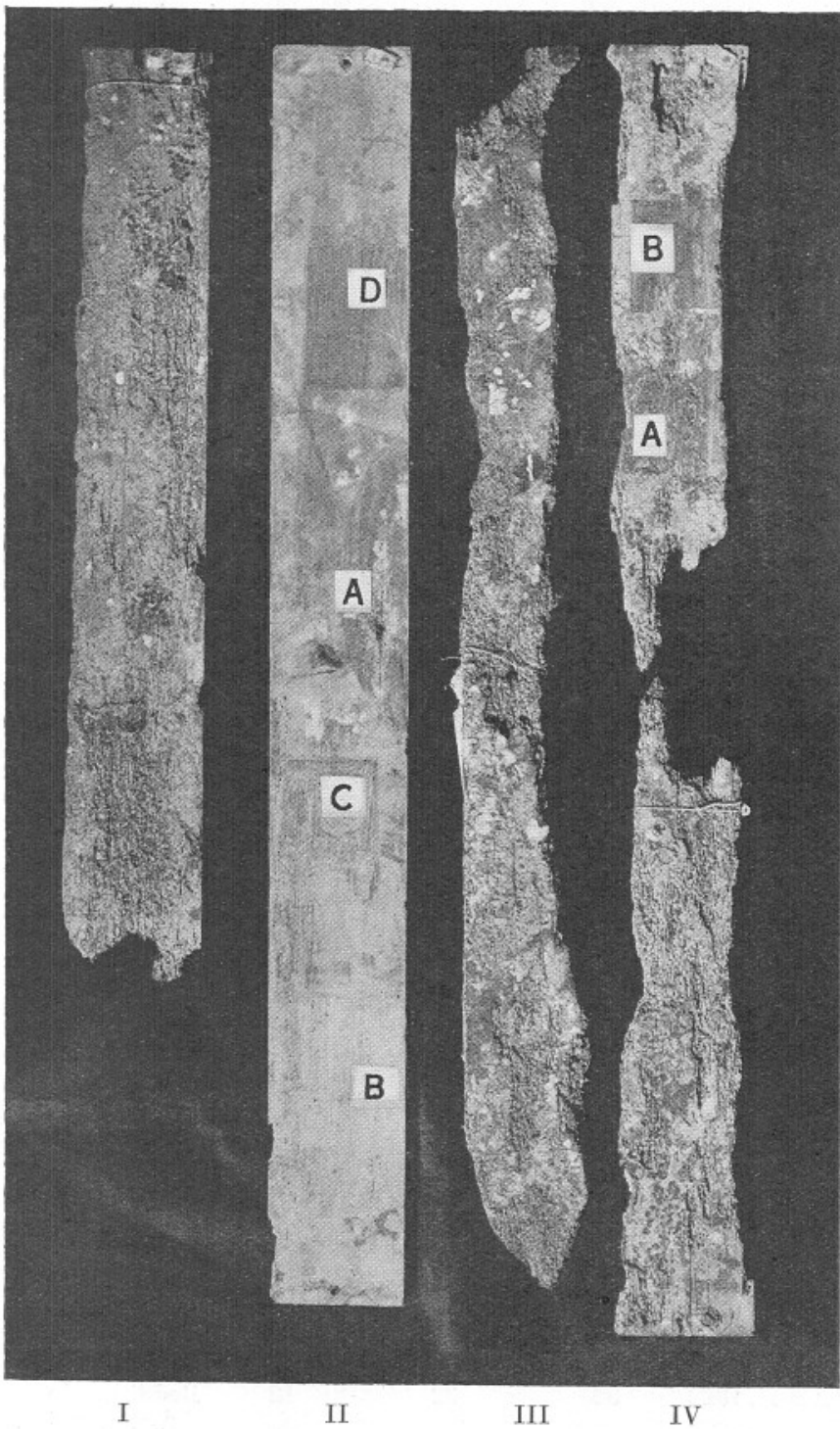

FIG. 13.- Photo of test-pieces from Experiment F, Great Western Railway Wharf, Millbay Docks, Plymouth, dried after exposure in the sea for $3 \frac{1}{2}$ years from August 27th, 1919, to March 7th, 1923. (× ca. $\frac{1}{7}$.) (Photo by D. P. Wilson.)

Test-piece No. I has had a small portion and the end of a Teredo tube broken off (see Fig. 12, p. 404).

Test-piece No. II shows the four areas B, C, A, and D (in order from below upwards) from which samples of paint were seraped for chemical analysis.

Test-piece III is shown from the side opposite to that shown in Fig, 12, p. 404

Test-piece IV shows the two areas, A and B, from which samples of paint were seraped for chemical analysis (compare IV, fig. 12, p. 404). 
this growth occurred while the untreated board remained devoid of growth. There is little doubt that all kinds of wood are liable to be slightly inimical to growths (and perhaps toxic) for a short period (i.e. a few weeks) after being put into the sea. The untreated board No. VII - comparable with the experimental boards-however; became covered with growth (after 15 weeks in the sea) and was eaten away to a remnant in 20 months. Four other boards, V, VI, (VIII and XII) and XI were eaten away to a remnant in 31 to 32 months, and four others, IV, I, III and IX became badly eaten away - though not reduced to a remnantin $42 \frac{1}{2}$ months, while as stated above No. II board remained almost intact at the end of the period of $42 \frac{1}{2}$ months. (See Figs. 12, 13, and 14.) It is therefore possible to estimate the preserving action on wood of the substances which were tested by taking as a basis for comparison the length of time required for the destruction of the untreated test-piece of wood, namely No. VII. In this way are derived the estimates of the preserving action shown in Table X, below. The value of each substance for inhibiting growth can be deduced from Table IX in a similar way, and is best shown in tabular form as in Table XI, p. 409.

TABLE X.

Rate of Destruction of the Test-Boards and the Deduced Preservative Value of the Substances Tested on Wood in Experiment F, Millbay Docks, Plymouth.

\begin{tabular}{|c|c|c|c|c|c|}
\hline & & & $\begin{array}{l}\text { Actual and } \\
\text { estimated* } \\
\text { periods for }\end{array}$ & & \\
\hline $\begin{array}{l}\text { No. of } \\
\text { test- }\end{array}$ & & Months in & & Value of & \\
\hline $\begin{array}{l}\text { board } \\
\text { and }\end{array}$ & Date eaten & $\begin{array}{l}\text { which test- } \\
\text { piece eaten }\end{array}$ & $\begin{array}{l}\text { test-boards } \\
\text { to a remnant }\end{array}$ & $\begin{array}{l}\text { preservative } \\
\text { action in }\end{array}$ & $\begin{array}{l}\text { Experimental } \\
\text { poisonous }\end{array}$ \\
\hline sub- & to remnant & to a remnant & in months & months & or other \\
\hline stance. & or brought in. & (approx.). & (approx.). & (approx.). & substance. \\
\hline VII & April 22nd, 1921 & 20 & 20 & - & Untreated. \\
\hline V & March 17th, 1922 & 31 & 31 & 11 & $\begin{array}{l}\text { Black-bronze : anti- } \\
\text { corrosive. }\end{array}$ \\
\hline VIII & ," & 31 & 31 & 11 & $\begin{array}{l}\text { Red oxide of iron : anti- } \\
\text { corrosive on iron. }\end{array}$ \\
\hline XI & ," & 31 & 31 & 11 & $\begin{array}{l}\text { Green : } \quad \text { anti-fouling } \\
\text { paint. }\end{array}$ \\
\hline XII & , & 31 & 31 & 11 & $\begin{array}{l}\text { Aluminium paint experi- } \\
\text { mental. }\end{array}$ \\
\hline VI & April 29th, 1922 & 32 & 32 & 12 & $\begin{array}{l}\text { Reddish brown anti- } \\
\text { fouling paint. }\end{array}$ \\
\hline IX & Lost & $28+a$ & 49 & 29 & $\begin{array}{l}\text { Black: ordinary black } \\
\text { varnish. }\end{array}$ \\
\hline IV & March 7 th, 1923 & $42 \frac{1}{2}+b$ & 49 & 29 & $\begin{array}{l}\text { Reddish brown anti- } \\
\text { fouling paint. }\end{array}$ \\
\hline $\mathrm{X}$ & ," & $42 \frac{1}{2}+c$ & 49 & 29 & Black: ordinary coal tar. \\
\hline I & , & $42 \frac{1}{2}+d$ & 49 & 29 & $\begin{array}{l}\text { Reddish brown anti- } \\
\text { fouling paint. }\end{array}$ \\
\hline III & , & $42 \frac{1}{2}+\mathrm{e}$ & 49 & 29 & $\begin{array}{l}\text { Black: anti-corrosive } \\
\text { paint. }\end{array}$ \\
\hline II & ", & $42 \frac{1}{2}+\mathrm{f}$ & 65 & 45 & $\begin{array}{l}\text { Green : } \\
\text { paint. }\end{array}$ \\
\hline
\end{tabular}

* Estimated periods are given in italics. 
An inspection of Table $\mathrm{X}$ brings out the somewhat surprising fact that the black-bronze anti-corrosive paint $(\mathrm{V})$, the green anti-fouling paint (XI), red oxide of iron (VIII), and aluminium paint (XII) all have an approximately equal value as preservative substances under the condition of the experiment. The red anti-fouling paint (VI) was only a little better than the preceding substances. The failure of these substances to preserve the test-boards is undoubtedly due to the readiness in which they become eroded off the test-boards, while the similarity in the rate of erosion suggests that the body used in these paints was essentially similar.

The substances IX, IV, X, I, and III were approximately equal in preserving value, and owed their increased value undoubtedly to their property of resisting erosion. It is a striking fact that ordinary coal-tar (X) and ordinary black varnish (IX, i.e. coal-tar diluted with naphtha) are as good preservatives as the more expensive paints III, IV, and I under the cònditions of these experiments.

The green anti-fouling paint (No. II) stands out in these experiments as a very efficient preservative and-as will be shown later-also a very valuable anti-fouling substance. A similar preservative value to that deduced above would be obtained by taking the relative condition of the boards on December 16th, 1921, after 28 months in the sea (see Table IX, p. 402).

The relative anti-fouling value of the substances tested in this experiment can be estimated approximately from the data given in Table IX. The dates at which general growth was first observed on each test-board gives the approximate time at which the anti-fouling value (if any) of each substance was lost. The intervals of observation are too widely spaced to give in most cases the date at which slight general growth occurred, but in the period between observations recording no growth (or slight growth) and general growth must have occurred the onset of general growth. This period in the case of each test-board is shown in Column 3, Table XI, p. 409. By taking the middle of this period, i.e. between the occurrence of no-or slight-growth and general growth, an approximate date is obtained for the onset of general growth, and this is given in column 4, Table XI. Since substances V and IX showed slight growth in one month, these may be safely stated to have no antifouling value (confirmed in other experiments), and the period required in the case of these two substances for the onset of general growth may be taken as the zero for the determination of the relative anti-fouling value of each substance. The relative values obtained in this way are given in Table XI, column 5. A detailed description of the boards recovered from the sea on March 7th, 1923, is given on pages 410-13. 


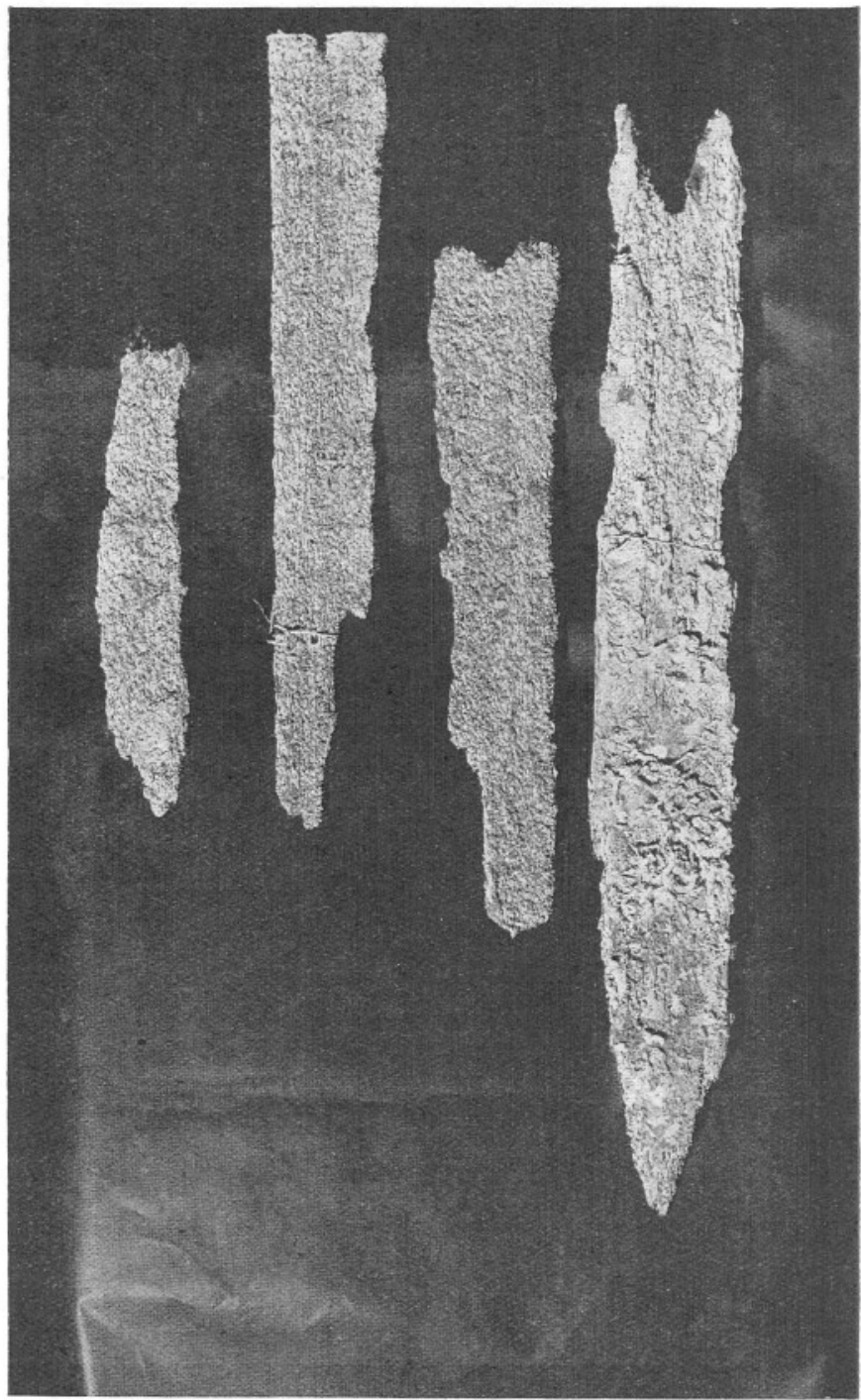

V

VI

VII

X

Frg. 14.-Photo of remnants of test-pieces from Experiment F, Great Western Railway Wharf, Millbay Docks, Plymouth, dried after various periods of exposure in the sea. $\left(\times \frac{1}{7}.\right)$ (Photo by D. P. Wilson.)

All the test-pieces were flrst exposed in the sea on August 27th, 1919. No. V test-piece remnant was taken out of the sea in March, 1922; No, VI in April, 1922; No, VII in April, 1921, and No. X in March, 1923. 
TABLe XI.

Rate of Infection of the Test-Boards in Experiment F with General Growth; and the Deduced Anti-Fouling Value of the Substances Tested (on Wood).

\begin{tabular}{|c|c|c|c|c|}
\hline $\begin{array}{c}\text { (1) } \\
\text { No. of } \\
\text { test-board } \\
\text { and } \\
\text { substance. }\end{array}$ & $\begin{array}{l}\text { (2) } \\
\text { Incidence of } \\
\text { slight growth } \\
\text { in months } \\
\text { (approx.). }\end{array}$ & $\begin{array}{l}\text { (3) } \\
\text { Incidence of } \\
\text { general growth } \\
\text { in months } \\
\text { (approx.). }\end{array}$ & $\begin{array}{l}\text { (4) } \\
\text { Time taken to } \\
\text { establish general } \\
\text { growth in months } \\
\text { (approx.). }\end{array}$ & $\begin{array}{c}(5) \\
\text { Relative } \\
\text { anti-fouling } \\
\text { value in months } \\
\text { (approx.). }\end{array}$ \\
\hline V & 1 & $1-2 \frac{3}{4}$ & $1 \frac{1}{2}$ & 0 \\
\hline IX & 1 & $1-2 \frac{3}{4}$ & $1 \frac{1}{2}$ & 0 \\
\hline VII & - & $1-2 \frac{3}{4}$ & $1 \frac{1}{2}$ & 1 \\
\hline $\mathrm{X}$ & $2 \frac{3}{4}$ & $2_{4}^{3}-6$ & $4 \frac{1}{2}$ & $3(0) \dagger$ \\
\hline III & - & $6-9$ & $7 \frac{1}{2}$ & $6(0) \div$ \\
\hline VI & 一 & $6-9$ & $7 \frac{1}{2}$ & 6 \\
\hline VIII & 一 & $9-12$ & $10 \frac{1}{2}$ & 9 \\
\hline XI & 一 & $9-12$ & $10 \frac{1}{2}$ & 9 \\
\hline XII & 一 & $9-12$ & $10 \frac{1}{2}$ & 9 \\
\hline IV & $12-20$ & $20-28$ & 24 & $22 \frac{1}{2}$ \\
\hline I & $12-28$ & $28-36^{*}$ & 32 & $30 \frac{1}{2}$ \\
\hline II & 28 nil & $36-42 \frac{1}{2} * *$ & 39 & $37 \frac{1}{2}$ \\
\hline
\end{tabular}

TABLE XII.

Comparative Anti-Fouling and Preservative Values Deduced From EXPERIMENT F.

No. of

sub-

stance. Colour and property.

CLASS A.

II Green : anti-fouling

I Reddish brown : anti-fouling

IV Reddish brown : anti-fouling

CLASS B.

IX Black (varnish) : experimental

X Black (coal-tar) : experimental

III Black : (anti-corrosive and preservative paint)

CLASS $C$.

V Black-bronze : anti-corrosive

VI Reddish brown : anti-fouling

VIII Red (oxide of iron) : experimental

XI Green: anti-fouling

XII Aluminium paint: experimental

CLASS D.

VII Untreated wood: greyish white
Deduced Deduced anti-fouling preservative value value Property found (in months). (in months). in Experiment F.

* The figures in italics are estimated. ** General growth on bottom of board only.

† See Experiment G, p. 415, and fig. 16, p. 414, for rapid overgrowth.

* See Experiment G, p. 415, and fig. 15, p. 412. No. III substance was tested in No. II inner bay, all the others being placed in outer bays, and was doubtless subjected to a lesser degree of infection in this situation. See also Table XV, p. 422, for rapid overgrowth. 


\section{The Anti-Fouling and Preservative Values Deducied from Experiment F.}

The estimated anti-fouling values (in months) deduced from Experiment F in Table XI, p. 409, and of the deduced preservative value (in months) in Table X, p. 406, for the various substances tested in this experiment are presented together in Table XII, p. 409. From this table it is seen that the substances fall naturally into four groups or classes as shown.

The results shown in Table XII are discussed on p. 426, after the consideration of experiments on painted shells, which were put out in the sea near the test-boards of Experiment F.

\section{Biological (and Chemical) Observations on the Test-Boards in Experiment F after $3 \frac{1}{2}$ Years' Exposure in the Sea.}

After the test-pieces in Experiment $\mathrm{F}$ had been in the sea for $3 \frac{1}{2}$ years the remaining boards were brought in to the Laboratory and photographed. Two of the boards, Nos. II and IV, were sent to the Government Chemist, London, for chemical analysis of samples of the paint in the condition of $(a)$ permitting over-growth, and $(b)$ apparently in the last stage of inhibiting growth. A report of these and other chemical analyses are given in Part II on pp. 430 to 437 , and a discussion of the results obtained is given on pp. 438 to 441 .

\section{Biological OBSERVATIONS}

No. II. Dark green anti-fouling paint.

The board retained its original size (see Fig. 12, p. 404). The front face of the test-board had a slight growth of hydroids in a small area (area A, Fig. 13) around the fixing nail in the middle and at one side. There was also a growth of hydroids on the lead (identifying) label on the top of the board. More or less paint was present on all the face except the lower six inches where were colonies of Diplosoma, Umbonula, and hydroids. There was no other growth on this face (Areas C and D, Fig. 13), but about 8 inches from the bottom in the middle of the face (Area B, Fig. 13) were four recent isolated borings of Limnoria (or Chelura). A few gribble borings were also present on the bottom of the board and around the middle fixing nail.

On the back face of the board paint still remained on the major part, but was missing from the lower 6 inches where Diplosoma and Halichondria were growing, and a few places where it had rubbed against the jarra pile. An area near the bottom of the board was eaten out by gribble over a surface of about $2 \times 1$ inches and to a depth of $1 \mathrm{~cm}$., and another area $5 \frac{1}{2}$ by $1 \frac{1}{2}$ inches was similarly eaten out on the back of the board around the middle fixing nail. But there was no other growth on the face.

At one side $(36 \times 1 \times 1$ inches) of the board the paint had almost disappeared and gribble had attacked most of one edge, but little of the other except at the bottom.

On the other side some paint remained except on the bottom $5 \frac{1}{2}$ inches. 
On the upper part of both the sides hydroids were growing abundantly with some Botryllus and Polydora ; while Diplosoma, Botryllus, Halichondria, and Polydora and gribble occurred on the lower parts. Limnoria and Chelura were taken from many places, but only in the lower three-fourths of these sides of the board. The top and bottom faces $(4 \times 1 \times 1$ inches $)$ of the boards were intact.

\section{No. I. Reddish brown anti-fouling paint.}

The lower 9 inches of the board were missing, having probably been eaten away. The upper portion (see Fig. 12, p. 404) had only patches of paint left on either the front or back face. In places where traces of the paint remained it was distinctly overgrown with Botryllus, Umbonula, and Polydora tubes. A specimen of Teredo, with a tube $18 \mathrm{~cm}$. long (slightly broken), remained projecting from the test-piece; the wood originally surrounding this tube having been eaten away by gribble. A large part of the face of both the front and back had been eaten away by gribble, and on the front face now were growing in abundance Polydora, Botryllus, Diplosoma, Balanus, and hydroids ; on the back were present the same organisms excepting Balanus. From the bottom of the board a sample of 50 gribble was examined and found to be Chelura terebrans, and at the top, among about 20 to 30 specimens, only a few were Limnoria.

\section{No. IV. Reddish brown anti-fouling paint.}

The test-board was eaten away in the middle, leaving two pieces (see Fig. 12, p. 404). The upper portion, 16-17 inches long, was eaten away at the sides to a width of $3 \frac{1}{4}$ inches. There was a good covering of paint over the outer face of the wood (of which Areas A and B were scraped and analysed chemically, see p. 434). The painted surface was unbroken in Area B, but perforated by Limnoria (or Chelura) in Area A, see p. 405, but was covered with a growth of Botryllus, Balanus, Umbonula, and Polydora, Pomatoceros and hydroids, especially a species of Obelia. The wood had been attacked by gribble in such a way as to leave in places a thin surface lamina covered by paint, a fact demonstrating the persistent, poisonous nature of the paint. The back surface of the wood (adjacent to the jarra pile to which it was fixed; and also remote from light) was eaten away over nearly the whole extent, probably having been undermined more quickly than on the front surface. The same kind of growth was found on the back as on the front.

The lower portion of the board also had a covering of paint still remaining over a good part of the front surface, but very little over the back. The paint on the front face was, however, overgrown very much with Botryllus and Diplosoma, several individuals of Balanus, and some Leucosolenia, Botrylloides, Polydora, and hydroids, and a pink sponge, probably a small colony of Hymeniacidon sp. Similar growth occurred at the back face, namely, Botryllus, Botrylloides, Diplosoma, but also Anomia and Umbonula.

\section{No. X. Ordinary coal tar.}

The board was almost entire, but eaten away by gribble around most of the original edges (see Fig. 12, p. 404). Paint still remained on nearly half of the outer-and mostly upper-face, and was in excellent condition on most of the back face. On the outer face the lower half was eaten away by gribble on the surface and almost to a point from the lower sides. Growing on the paint in the upper part of this face were Halichondria, Botryllus, Diplosoma, Hymeniacidon, Morchellium, Actinoloba (brown), and a fair amount of worms. On the back face were growing Halichondria, Botryllus, Diplosoma, Umbonula, Pomatoceros, Balanus, Anomia, hydroids, and a few Sabellid worms. 


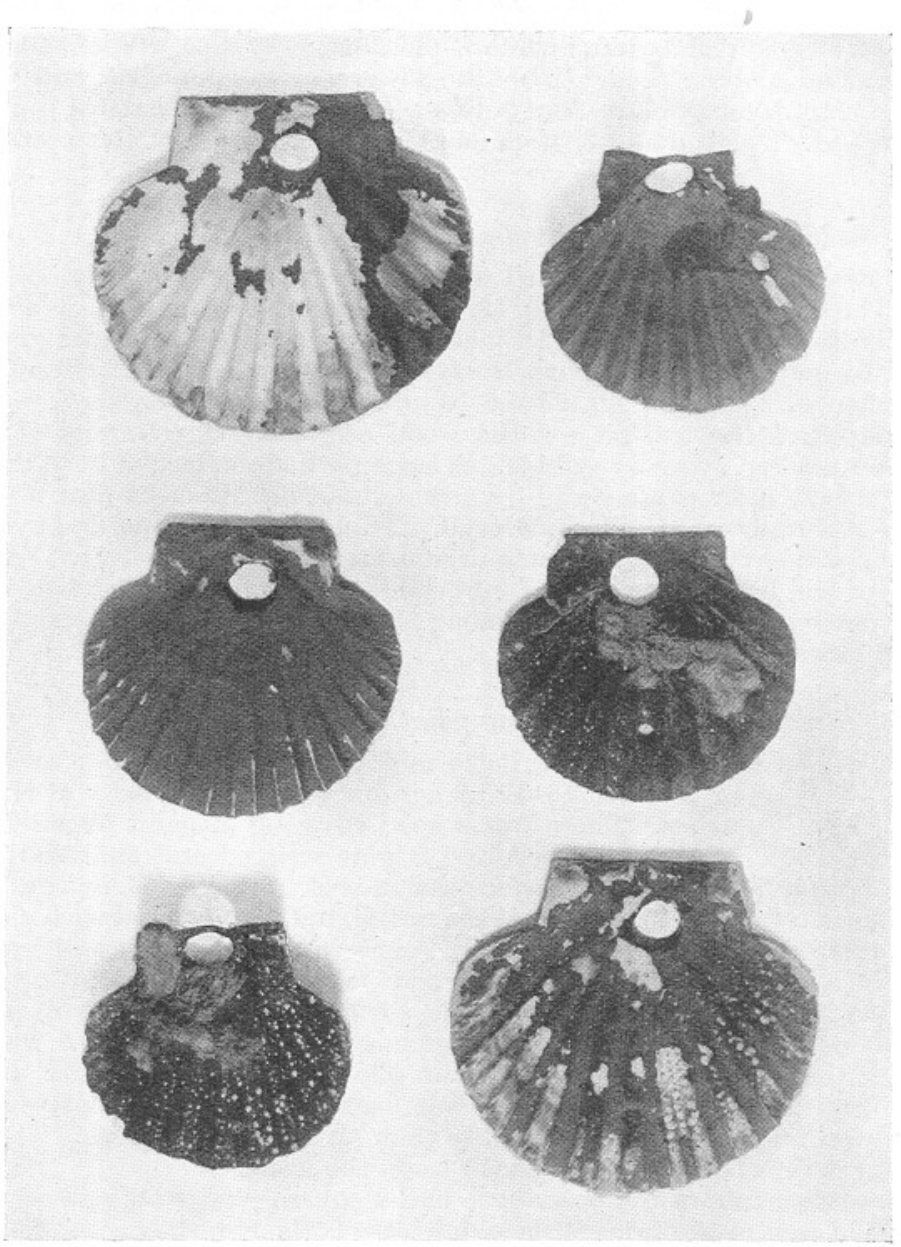

Fig. 15.-Photo of shells exposed at the Great Western Railway Wharf, Millbay Docks, Plymouth, Experiment G, from August 28th, 1919, to May 4th, 1920. ( $\times$ ca. $\frac{2}{5}$.) (Photo by D. P. Wilson.)

I Red : view of inner smooth surface of a flat shell showing the paint washing away but devoid of growth. (The paint on rough surface-not seen-is almost entire.)

II Dark green : view of inner smooth surface of a flat shell, which is losing paint only at the right-hand upper corner and on certain ridges. There is no growth on this shell. (The paint on the rough surface - not seen-is almost entire.)

III Black : view of inner smooth surface of a convex shell showing the laver of paint to be entire. There is a growth of Halichondria, Leucosolenia, and a hydroid, and a good spatting of Balanus. (The paint on the reverse surface is also entire.)

IV Red : view of inner smooth surface of a convex shell showing the layer of paint to be almost entire. There is no growth on this shell. (The paint on the reverse surface is also almost entire.)

$\mathrm{V}$ Black-bronze: view of outer rough surface of a flat shell showing the paint entire and a growth of Ascidians, hydroids, Balanus, and young polychretes. (The inner smooth (reverse) surface shows a slight denudation of paint.)

VI Red: view of inner smooth surface of a flat shell showing the paint denuded from considerable areas and the spatting of Balanus on the bare shell and on the areas still retaining paint. (The paint on the reverse rough surface is almost entire.) 
No. III. Black : anti-corrosive and preserving paint.

The test-piece retained the original length of about 3 feet, but was badly eaten away from one edge. An original edge on half of one side remained with paint on it and was only slightly bored by gribble (see Fig.12, p. 404). The front face along the middle of its length had paint still adhering in very good condition, but was covered everywhere with growth. At the top of the face was much Diplosoma and Botryllus, a few Ascidiella and Botrylloides and a fair amount of encrusting Polyzoan : in the middle was very much Halichondria and Umbonula and a fair amount of Botryllus and Diplosoma, one Pomatoceros, and hydroid colonies : on the bottom of the front face was a lot of Botryllus and Umbonula, a little Diplosoma and a fair amount of the small Sabellid.

On the back face of the board, which was much more eaten by gribble than the front, where the paint remained, it was in good condition; there was a growth of Sabellid tubes everywhere, eight Balanids, one Anomia, one Pomatoceros, and a little Botryllus and Halichondria.

\section{Experiment G.}

Shells of the scallop, Pecten maximus, were painted (in lots of ten) with the substances I to XII (see p. 376) (except No. VII, which is - as in all the experiments - untreated material) and put out on tarred rope around the cement supporting piles of the West Wharf, Millbay Docks, Plymouth, on August 28th, 1919, at low water spring-tide level. Two shells of each of the twelve kinds were strung round each of the following piles, counting from the south end of the south division of the wharf :4th row 2 nd pile (=4R $2 \mathrm{P})$, $5 \mathrm{R} 2 \mathrm{P}, 6 \mathrm{R} 2 \mathrm{P}, 7 \mathrm{R} 2 \mathrm{P}, 8 \mathrm{R} 2 \mathrm{P}$; while on $9 \mathrm{R} 2 \mathrm{P}$ were strung a number of shells, all of which were clean, or rather untreated. The 4 th row of piles separates the 3 rd from the 4 th bays, and the 5th row separates the 4th and 5th bays, and so on. Th experimental material in Experiment $\mathrm{F}$ was put out on jarra piles in bays 3 to 14 adjacent to the cement piles (about 2 yards distant) used for this experiment. Thus the sites in the two experiments were essentially similar though the upper half of each test-board would be above the level of the shells; the shells would be also rather more shaded from light than the boards, and about 1 yard further from the small beach, which is exposed at low water at the back, i.e. inner part, of the wharf.

Observations on this experiment were only carried out over a period of 19 months (owing to the absence of the investigator on other work), but the period was sufficient to discover most of the results obtainable from an experiment of this kind. An examination of and report on individual shells was made on four inspections and general observations made on others. These observations are summarised in Table XIII, p. 415 , and the results of the experiments are shown on Figs. 15 and 16, pp. 412 and 414. 


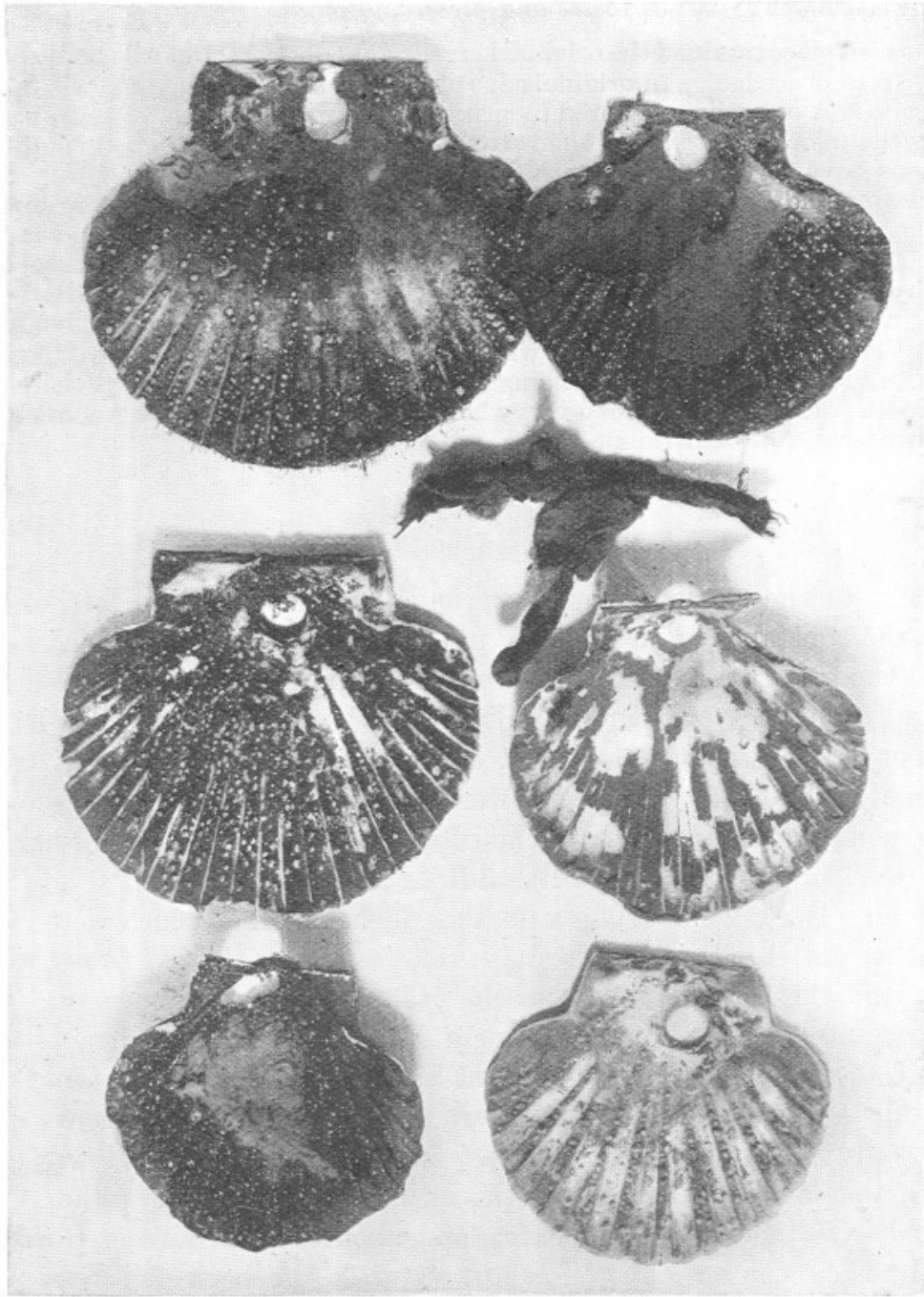

Fig. 16.-Photo of shells exposed at the Great Western Railway Wharf, Millbay Docks, Plymouth, Experiment G, from August 28th, 1919, to May 4th, 1920. ( $\times$ ca. $\frac{2}{5}$.) (Photo by D. P. Wilson.)

VII Untreated shell : view of inner smooth surface of a flat valve with a slight growth of Halichondria, much hydroid growth and spat of Balanus with also young tubicolous Sabellid polychretes. The growth on the reverse rougher side is similar.

VIII Red : view of inner smooth surface of a flat shell showing areas denuded of paint, Balanus spat on the paint, and a slight growth of tubicolous polychretes around the larger hole. On the rougher reverse side the paint is practically entire, but with similar growth.

IX Black: view of inner smooth surface of convex valve showing the paint almost entire, a good growth of Halichondria, hydroids and Balanus, and a few tubicolous polychetes. The reverse side is similar.

X Black: view of inner smooth surface of a convex valve showing the paint almost entire, a good growth of Botryllus, Diplosoma, and Balanus. The reverse side is similar without Diplosoma.

XI Light Green: view of inner smooth surface of convex valve showing large areas denuded of paint and no growth. On the reverse side the paint is denuded, but to a smaller extent.

XII Silvery : view of inner smooth surface of a flat valve, showing the almost complete absence of paint. a good spatting of Balanus, and a nest of tubicolous polychrtes around the large hole. The reverse side is similar, but more paint remains in the roughened hollows.

The T-shaped black object between shells X and XI consists of a horizontal piece of tarred rope on which is growing a large mass of Botryllus and a little Leucosolenia, 
Table XIII. Experiment G.

\section{Observations on Growths (and Condition of Paint) on Untreated Shells and Shells Treated with Various Substances (I to VI, AND VIII to XII, SEE P. 376) AND PUt IN the Sea on August 28th, 1919, at the West Wharf, Mullbay Docks, Plymouth.}

\begin{tabular}{|c|c|}
\hline & $\begin{array}{l}\text { Sept. } 25,1919 \\
\text { (exposed } 4 \text { weeks). }\end{array}$ \\
\hline $\begin{array}{l}\text { I } \\
\text { Reddish brown } \\
\text { anti-fouling }\end{array}$ & No growth \\
\hline $\begin{array}{c}\text { II } \\
\text { Green } \\
\text { anti-fouling }\end{array}$ & No growth \\
\hline$\underset{\text { Black }}{\text { III }}$ & $\begin{array}{l}\text { Halichondria and a } \\
\text { Polyzoan on } 2 \text { shells, } \\
\text { other shells no } \\
\text { growth }\end{array}$ \\
\hline$\frac{\text { IV }}{\text { Reddish brown }}$ & No growth \\
\hline
\end{tabular}

Dec. 8,1919
exposed 14 weeks).

No growths; paint No growth: paint good, chipping a eroding little on smooth faces

Feb. 7, 1920

May 19, 1920

exposed $c, 9+$ months (see notes 1-3 below)

Paint entire on some shells, slightly washer off on others

Balanus spat on bare shell and a few also on paint

No growth: paint No growth: paint Paint mostly entire, good slimy but still good slight growth only on naked shell

Heavy growth on all in good to very good condition (see Table XIV) No growth; paint No growth good

Covered with growths paint not examined still entire on some

anti-fouling

V

Black-bronze anti-corrosive

VI

Reddish brown anti-fouling

VII

Greyish white untreated shells

$\begin{array}{ll}\text { VIII } & \text { juv., on the others } \\ \text { Red } & \text { already sticky }\end{array}$

IX

Black (varnish) experimental

X

Black coal-tar experimental

$$
\begin{gathered}
\text { XI } \\
\text { anti-fouling }
\end{gathered}
$$

Three shells with a little growth of Halichondria and young organisms

No growth

Three shells without growth. Halichondria, Hydroids, Botryllus, Hymeniacidon ryllus, Hymeniacidon juv., and Amphipod nests, Diplosoma juv., on the others
lus,Pomatoceros, $\mathrm{Hy}$ droids, and Amphispat No growth Covered with Dip-
All but two shells with little to much growth (see Table XIV): paint good on most shells

No growth, paint already eroding already

(1)

Growth on all shells but one (see Table some shells now XIV)

Much Diplosoma on
one shell, others no
growth, but paint growth, but eroding fast reported on off on some sides devoid of growth
Some shells without growth, paint not

No growth ; paint spongy: nearly all

Paint eroding, but shells. A few Balanus spat actually on the paint. No growth on one shell

Shells covered with growth of various. kinds : paint good

Paint good on a few shells, but is mostly badly eroded. A few Balanus on paint as well as on naked shell All shells covered with good growths mainly of Botryllus, Balanus, and Diplosoma

One shell covered others with paint spongy and eroding fast

Some shells still covered with paint but washed off others. Spat chiefly of Balanus is now established on the paint also (see note 4 below) Seven shells covered All shells with Some shells now All shells covered with
with growth of growth: paint good without growth: growth: paint good Halichondria, Hy- on most shells (see paint good

meniacidon, Botryl. Table XIV)

pod (?) nests
Four shells with Six shells with, 4 Good growth on All shells covered growth of Halichon- without growth: shells with growth: paint dria, Ascidiella spat, paint good on most and other unknown shells (see Table XIV)

No growth ; paint No growth; paint eroding easily washing off good

Some shells with paint entire but with little to much growth, chiefly of Balanus, on the paint as well as on the bare shell

No paint or only a trace left. All shells covered with growth

No growth

Growth on 6 shells, Not observed but paint nearly all washed off all

Aluminium paint
Silvery and

1. August 16th, 1920. (Exposed about 12 months.) All the shells were restrung with tarred twine in the hope of further extended observations. On this date all the shells were found to be overgrown with marine animals of different kinds except the reds IV and I and the green No. II. In the case of No. II the paint was washed off most of the shells to some extent, and growths were found on the naked shell, but not on the paint.

2. September 30th, 1920. (Exposed about 13 months.) IV Red: Paint still good in parts on the rough side of the shell, there was little other growth than a few Balanus on the paint, but much on the denuded parts of the shell. II Green: Paint only good on the rough side of the shell where there is no growth: fair growth on those parts of the smooth side where paint is now washed off. Only 6 and 8 row sets of shells remained, the others having been lost.

3. April 23rd, 1921. (Fxposed about 19 months.) Three shells of each of the paints I, II, and IV were collected and sent to the Government Chemist for chemical analysis of the parts. Only slight growth present on the paint, but shells otherwise with abundant growth.

4. Balanus spat have bored through the red oxide which is being pushed up on to the sides of the shell as the shell grows. The same phenomenon occurs when Balanus settles on red oxide on the bottoms of ships, and especially on surfaces covered with coal-tar, pitch, or varnish. 


\section{The Growth on Individual Shells in Experiment G on December

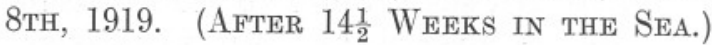

The growths found on the individual shells in experiment $G$ on

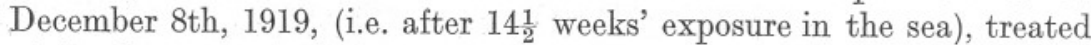
with substances III, V, IX, X, and the untreated shells (VII) are conveniently shown in Table XIV, below. It is noteworthy that the condition of the paints III, V, IX, and $\mathrm{X}$, which are all black, was at this time very good; only occasional flaking occurred on the smoother side of the shells. The growths found on the painted shells therefore occurred actually on the paint and not on parts of the shell denuded of paint, as was the case, for example, with No. XII shells on this date and others later.

\section{TABLE XIV.}

Growths found on December 8th, 1919, (after 14 $\frac{1}{2}$ Weeks in the Sea), on the separate Shells Treated with Substances III, V, IX, and X, and the Untreated Shells in Experiment G, West Wharf, Millbay Docks, Plymouth.

VII III V

\begin{tabular}{|c|c|c|}
\hline $\begin{array}{l}\text { No. of } \\
\text { shell. }\end{array}$ & $\begin{array}{l}\text { Untreated } \\
\text { shells. }\end{array}$ & $\begin{array}{l}\text { Black anti- } \\
\text { corrosive. }\end{array}$ \\
\hline 1 & $\begin{array}{c}\text { Halichondria } \\
4 \text { colonies }\end{array}$ & Botryllus \\
\hline 2 & $\begin{array}{l}\text { Ascidiella } \\
\text { young }\end{array}$ & $\begin{array}{l}\text { Diplosoma } \\
\text { Botryllus }\end{array}$ \\
\hline 3 & $\begin{array}{l}\text { Halichondria } \\
\text { Diplosoma } \\
\text { Umbonula }\end{array}$ & $\begin{array}{l}\text { Diplosoma } \\
\text { Ascidiella } \\
\text { young }\end{array}$ \\
\hline 4 & Hydroids & Diplosoma \\
\hline 5 & $\begin{array}{l}\text { Halichondria } \\
\text { Botryllus } \\
\text { Diplosoma }\end{array}$ & $\begin{array}{l}\text { Diplosoma } \\
\text { Pomatoceros } \\
\text { Anomia }\end{array}$ \\
\hline 6 & None, dirty & $\begin{array}{l}\text { Ascidiella } \\
\text { Polydora } \\
\text { Umbonula } \\
\text { Anomia }\end{array}$ \\
\hline 7 & $\begin{array}{l}\text { Diplosoma } \\
\text { Anomia } \\
\text { Umbonula }\end{array}$ & None \\
\hline 8 & Botryllus & Anomia \\
\hline 9 & $\begin{array}{l}\text { Botryllus } \\
\text { Diplosoma }\end{array}$ & $\begin{array}{l}\text { Botryllus } \\
\text { Diplosoma } \\
\text { Halichondria } \\
\text { Hydroids }\end{array}$ \\
\hline 10 & $\begin{array}{l}\text { Diplosoma } \\
\text { a little }\end{array}$ & None \\
\hline
\end{tabular}

Black-bronze Black varnish Black coal-tar anti-corrosive. experimental. experimental.

None Diplosoma Diplosoma

abundant

Halichondria Halichondria 5 colonies

Diplosoma

Diplosoma Diplosoma None

Ascidiella Halichondria young

Diplosoma

Halichondria

Halichondria

Halichondria 5 colonies

Ascidiella
young
$\begin{gathered}\text { Diplosoma } \\ \text { Ascidiella } \\ \text { young }\end{gathered}$

None Diplosoma
abundant

Anomia
Nudibranch
spawn

Hydroids

None

Diplosoma Ascidiella juv. Polydora

Diplosoma Polydora

Diplosoma

Diplosoma

Botryllus

Pomatoceros young

Pomatoceros

Halichondria

Botryllug

Diplosoma

Halichondria

Polydora
None

Diplosoma

Botryllus

Halichondria a little

None 


\section{Summary of Results from Experiment $G$.}

The most important results obtained from Experiment G are (1) the capacity of the different substances tested for resisting or permitting growth in the first few months of exposure in sea-water, and (2) the capacity of the different substances tested for resisting erosion fromor adhering to-rough and smooth surfaces.

The observations made on December 8th, 1919, and recorded in Table XIV, show that all the black paints, i.e. III, V, IX, and X, while remaining in good condition, permitted extensive growth to occur, while the observations made on September 25th, 1919 (see Table XIII), show that even in four weeks the same substances already had slight growths on them of the same kind as occurred on the untreated shells (VII) at that time. These substances must, therefore, be regarded as non-toxic, or at the most only slightly toxic, to the kinds of organisms shown in Table XIV. After nine months' exposure in the sea these paints remained in good condition and adhered to the shells better than the other paints, and were not again reported on. These paints need not be further considered in this experiment.

After $14 \frac{1}{2}$ weeks in the sea, paints VI, VIII, XI, and XII were found to be eroding fast, while I, II, and IV remained mostly in good condition, except for slight flaking on the smoother faces of the shell. At this time growths occurred on VIII and XII, but as the paint was already nearly all washed off the latter (XII), growth may have begun originally on the denuded parts of the shell. No. XII paint, therefore, was eroded in so short a period as $14 \frac{1}{2}$ weeks in this experiment and need not be further considered, except that it could be regarded as preventing marine growths for one month (see Table XIII).

After 6 months in the sea the following paints remain to be considered, namely I, II, IV, VI, VIII, and XI. Of these No. VI was spongy and washed almost completely off some of the shell-faces; Nos. VIII and XI were soft and also being rapidly eroded; the other paints remained good, but No. I was washing away to some extent.

After 9 months in the sea the paints VI, VIII, and XI were washed off most shells, and even where they remained permitted growths of Balanus. Nos. IV and I were also washing off to some extent and permitted Balanus to settle on the paint. No. II remained in the best condition, being washed off the shell in small areas in a few cases. In some of such cases growth had occurred on the denuded shell area.

After 12 months in the sea all shells were covered with growths except those painted with Nos. IV, I, and II ; of these Nos. IV and I permitted growths of Balanus on the paint itself, but no growth occurred actually 
on No. II paint, although occurring on clean denuded areas of shell adjacent to the paint.

After 13 months in the sea the condition was almost the same as after 12 months. The paints II and IV still adhered well to the rougher faces of the shell, but was more or less washed off the smoother faces. No. IV still only permitted the growth of a few Balanus, while No. II still inhibited all kinds of growth, although not preventing such on adjacent clean shell area. No. I paint was not reported on on this examination.

After 19 months in the sea, shells, still covered with the paints IV, I, and II, and permitting little or no growth, were taken out of the sea and sent immediately to the Government Chemist for separate chemical analyses of the paints at this stage.

The results of this experiment confirm those in Experiment D especially, in which the paints were found to wash off the smooth side of the shells to a great extent in about 13-14 months. This period is not long enough to test fully the anti-fouling value of the more efficient kinds of poisonous paints, e.g. II, IV, and I, but serves to demonstrate the fundamental importance of the capacity of a paint of this kind $(a)$ to withstand erosion and $(b)$ to adhere to the surface to which it is applied. This and the other experiments with shells fully prove that all the paints adhere better to, and erode less quickly from, a rough than a smooth surface. In this experiment the anti-fouling paint VI eroded more quickly than VIII, and was, therefore, of less value for keeping down growth from this fact alone, whatever poisonous properties that paint may have had before erosion. It is obvious that an anti-fouling paint has lost its value as such as soon as it is washed away, therefore the degree to which an anti-fouling paint resists erosion while retaining its growth-inhibiting properties is a fundamental property of such paints.

SERIES III. PROMENADE PIER, PLYMOUTH.

\section{Experiment $H$.}

In this experiment the following substances only were tested, namely IV, anti-fouling paint; VIII, red oxide of iron paint ; IX, black varnish ; $\mathrm{XV}$, a common grey paint; along with VII, untreated shells; XIII, sheets of copper 4 inches square; and XIV, sheets of zinc of the same size. The tarred rope (tarred with coal-tar and well dried) provided an additional experiment with No. X substance. The shells were painted with each paint, in lots of sixteen, and strung on tarred rope around the piles of the Promenade Pier at the level of low-water spring tides. Twenty shells were put out around each pile in two horizontal rows each containing ten shells, and in such a way that a clean shell alternated 


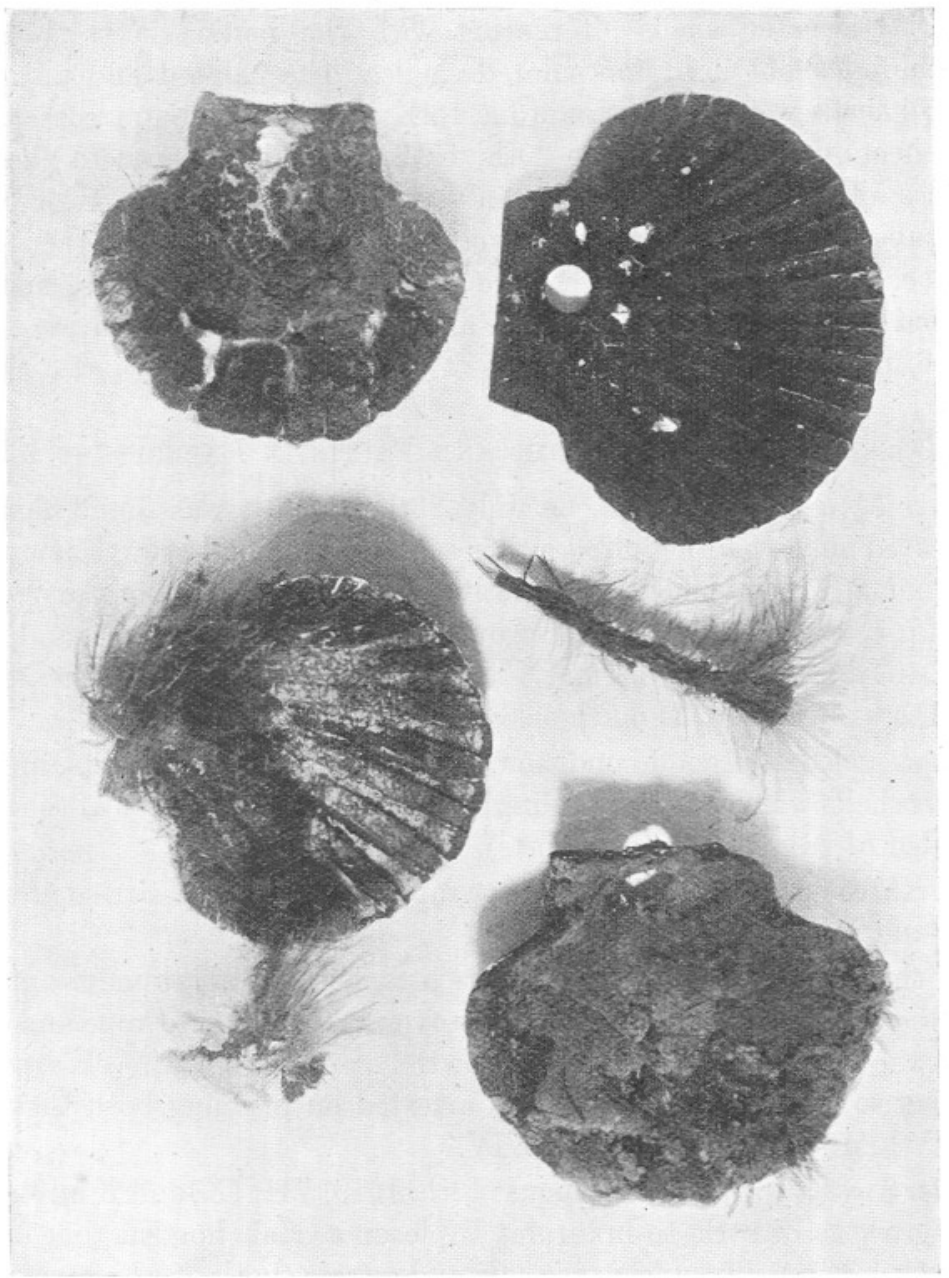

Fig. 17.-Photo of shells from Experiment H, Promenade Pier, Plymouth, exposed in the sea from June 18th, 1919, to September 13th, 1919. ( $\times$ ca. $\frac{2}{5}$.) (Photo by D. P. Wilson.)

VII Untreated shell covered with a growth of six or seven distinct colonies of Botryllus, and with a slight growth of hydroids.

VIII Red : view of smooth inner surface of shell showing the paint washed off to a great extent and with mature Plumularia and Clytia overgrowing both the paint and the denuded shell. The reverse surface showed denudation of paint to a smaller extent, but hydroid growth both on paint and naked shell. showed denudation of paint to a smaller extent, but hydroid growth both on paint and naked shell.
The tarred rope still attached to this shell showed a luxuriant growth of Halichondria, Diplosoma, and ripe Plumularia.

IV Red : view of smooth inner surface of a flat valve, showing only slight loss of paint and no growth : the reverse side showed no loss of paint and no growth.

IX Black: view of smooth inner surface of a convex valve covered with colonies of Botryllus overgrowing the paint and ripe Plumularia and Clytia. The reverse side showed slight loss of paint on the ridges and similar luxuriant growth.

The piece of tarred rope between IX and X shells shows also a heavy growth of ripe Plumularia. 
with a treated shell (with rare exceptions) both vertically and horizon tally. Untreated shells alternating with the metal sheets were put out on piles not used for painted shells. The painted and untreated control shells were put out on June 18th, 1919, and the untreated shells and sheets of metal on June 20th, 1919. In this experiment the sub. stances VIII, IX, and XV were only painted on the shells in one coat, but substance IV was given two coats. In all the other experiments. two coats of each substance were applied. The shells were suitably marked by borings differing in size and position for identification. (See Fig. 6, p. 385.)

\section{Observations on Growths and Paints in Experiment H.}

After $5 \frac{1}{2}$ weeks in the sea, on July 26th, 1919, it was found that the untreated shells had acquired either a little or a good growth mainly of Diplosoma (which yielded living active tadpoles in the Laboratory), Halichrondria, Plumularia (ca. half-grown colonies in abundance), and some Mytilus spat. Shells with No. IX substance and the tarred rope, X, had growths as luxuriant as on the clean shells.

IV was clean, in good condition, and without growth, except in three or four shells which showed slight growth (doubtless on parts of the shells denuded of paint, see later reports).

On XV the paint was washing away rapidly and already carried growths. XIII and XIV showed no growth.

On the pile to which the shells were attached was an abundant growth of Halichondria panicea which rapidly overgrew the tarred rope and crept on to the clean shells. Creeping growths of this kind were observed on this day to have been undoubtedly arrested on reaching both the paint No. IV and the zinc sheets No. XIV.

After 8 weeks in the sea, on August 12th, 1919, VII, IX, and X all showed good growths of little to luxuriant Diplosoma, Halichondria (one colony $3.2 \times 2 \times 1 \mathrm{cms}$.), Plumularia pinnata and setacea (both of which extruded planulæ), Clytia (which yielded medusæ), Botryllus (one colony with fifteen whole and three half-systems), and other hydroids. XIII showed no growth, but of XIV (zinc) one sheet had a small colony $10 \times 3 \mathrm{~mm}$. of Halichondria which had almost certainly grown from a larva.

$\mathrm{XV}$ had fair growths and VIII a little growth on two shells, but none visible on others.

After $12 \frac{1}{2}$ weeks in the sea (see Fig. 17, p. 419), on September 13th, 1919, a detailed report on the shells was made which may be summarised as follows :-

VII, untreated shells: four shells with little growth, others (ca. 70) mostly covered with growths of Botryllus, Diplosoma, Plumularia, Clytia, 
Bougainvillea, and other hydroids. One shell placed between two sheets of copper had no visible growth on this day.

IV, reddish brown anti-fouling paint. All shells without growth and the paint in good condition and entire on nearly all the shells.

VIII, red oxide; the paint is washed off the inside (smooth face) of most shells. Five shells with no growth, others with small growth of hydroids, others with young colonies of a compound Ascidian (probably Morchellium) and Botryllus and Diplosoma overgrowing the paint.

IX, black varnish shells covered with same growth as on others, and paint still good.

$\mathrm{X}$, tarred rope with luxuriant growths and overgrowths.

XIII, copper sheets; all without growth.

$\mathrm{XIV}$, zinc sheets; thirteen no growth, two with slight hydroid growth, one with a small colony of Halichondria now $12 \times 5 \mathrm{~mm}$.

$\mathrm{XV}$, the grey paint is almost all washed away on all shells, which have now acquired little to luxuriant growths. On this day tadpoles of Botryllus and Diplosoma were obtained from samples of the growth on the material, and medusæ of Clytia from isolated colonies. On September 15th numerous Folliculina ampullaria were obtained in a bowl from material isolated September 13th. This species had passed through a reproductive phase in the Laboratory. On October 24th three sets of shells were missing. Bougainvillea ramosa collected from the experimental material gave off medusæ.

After 25 weeks in the sea, on December 9th, 1919, the shells, No. IV, showed no growth, but the paint was washing off badly on the smoother side of the shells. Bougainvillea colonies and Sycon were now abundant on most of the other material, in addition to the organisms already recorded.

After $8 \frac{1}{2}$ months in the sea all the No. IV shells had lost a large amount of paint; one shell had no paint at all left. There was, however, no growth on the residual paint itself.

Many of the untreated shells, No. VII, were being washed clean by the wave-action resulting from heavy gales; colonies of Botryllus were found just hanging on to the shells.

On February 21st, 1920, the shells were restrung with fresh rope or trawl twine.

On August 18th, 1920, many strings of shells were missing. Four sheets of copper were found to be very thin, but there occurred a luxuriant growth of organisms all around the copper sheets which obviously have no effect on keeping down growth to within a distance of even a few millimetres. There was, however, no growth on the copper itself.

On this day Halichondria from the shells yielded embryos. No further observations were made. 
Summary of Results from all Experiments, showing incidence of Growths* and Final Condition of the Substances Tested.

\begin{tabular}{|c|c|c|c|c|c|c|c|c|c|c|}
\hline \multirow{4}{*}{\multicolumn{2}{|c|}{$\begin{array}{l}\text { Experiment } \\
\text { Observations }\end{array}$}} & \multicolumn{4}{|c|}{ CAWSAND BAY } & \multicolumn{3}{|c|}{ WEST WHARF } & \multicolumn{2}{|c|}{ Prom. Pier } \\
\hline & & \multirow{3}{*}{$\begin{array}{l}\text { A and B } \\
\text { on wood }\end{array}$} & \multirow{3}{*}{$\stackrel{\mathrm{C}}{\text { on wood }}$} & \multicolumn{2}{|c|}{$\mathrm{D}$ and $\mathrm{E}$ on shells } & \multirow{3}{*}{$\begin{array}{c}F_{8}^{8} \\
\text { on wood }\end{array}$} & \multicolumn{2}{|c|}{ G on shells } & \multicolumn{2}{|c|}{$\mathrm{H}$ on shells } \\
\hline & & & & $\begin{array}{l}\text { smooth } \\
\text { surface }\end{array}$ & $\begin{array}{r}\text { rough } \\
\text { surface }\end{array}$ & & $\begin{array}{l}\text { smooth } \\
\text { surface }\end{array}$ & $\begin{array}{c}\text { rough } \\
\text { gurface }\end{array}$ & $\begin{array}{l}\text { smooth } \\
\text { surface }\end{array}$ & $\begin{array}{l}\text { rough } \\
\text { surface }\end{array}$ \\
\hline & & & & & & & & & & \\
\hline \multirow[t]{2}{*}{ I } & $\begin{array}{l}\text { Growth } \\
\text { in period }\end{array}$ & $\begin{array}{l}\text { little } \\
14 \text { months }\end{array}$ & $\begin{array}{l}\text { fair amount } \\
14 \text { months } \\
\text { somet }\end{array}$ & $\begin{array}{l}\text { abundant } \\
14 \text { months } \\
\text { trace }\end{array}$ & $\begin{array}{l}\text { abundant } \\
14 \text { months }\end{array}$ & $\begin{array}{l}\text { little } \\
12 \text { to } 28 \text { months } \\
\text { fair amount }\end{array}$ & $\begin{array}{c}\text { little } \\
9 \mathrm{~d} \text { months } \\
\text { eroding slightly }\end{array}$ & $\begin{array}{c}\text { little } \\
91 \text { months } \\
\text { eroding slightly }\end{array}$ & - & - \\
\hline & in period & 14 months & 14 months & 14 months & 14 months & $\begin{array}{l}28 \text { months } \\
\text { trace } 42 \ddagger \text { months }\end{array}$ & 91 months & 91 months & & \\
\hline \multirow[t]{3}{*}{ II } & Growth & trace & little & abundant & none & none & none & none & & \\
\hline & $\begin{array}{l}\text { in period } \\
\text { paint }\end{array}$ & $\begin{array}{l}14 \text { months } \\
\text { entire }\end{array}$ & $\begin{array}{l}14 \text { months } \\
\text { some }\end{array}$ & 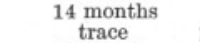 & $\begin{array}{l}14 \text { months } \\
\text { partly washed away }\end{array}$ & $\begin{array}{l}28 \text { months } \\
\text { fair amount }\end{array}$ & $\begin{array}{l}13 \text { months } \\
\text { much eroded }\end{array}$ & $\begin{array}{l}13 \text { months } \\
\text { slightly eroded }\end{array}$ & - & - \\
\hline & in period & 14 months & 14 months & 14 months & 14 months & $42 \$$ months & 13 months & 13 months & & \\
\hline \multirow[t]{3}{*}{ III } & Growth & fair amount & abundant & abundant & abundant & abundant & slight & slight & & \\
\hline & $\begin{array}{l}\text { in period } \\
\text { paint }\end{array}$ & $\begin{array}{l}6 \text { weeks } \\
\text { good }\end{array}$ & $\begin{array}{l}6 \text { weeks } \\
\text { some }\end{array}$ & $\begin{array}{l}\text { from } 6 \text { weeks } \\
\text { partly washed off }\end{array}$ & $\begin{array}{l}6 \text { weeks } \\
\text { entire }\end{array}$ & $\begin{array}{l}\text { from 6-9 months } \\
\text { good where not }\end{array}$ & $\begin{array}{l}4 \text { weeks } \\
\text { not recorded }\end{array}$ & $\begin{array}{l}4 \text { weeks } \\
\text { not recorded }\end{array}$ & - & 一 \\
\hline & in period & 14 months & 14 months & 14 months & 14 months & eaten, $42 \frac{1}{2}$ mths. & 13 months & 13 months & & \\
\hline \multirow[t]{3}{*}{ IV } & Growth & little & little & fair amount and & none to little & little & little & little & none & none \\
\hline & in period & 14 months & 14 months & $\begin{array}{c}\text { abundant } \\
14 \text { months }\end{array}$ & 14 months & 12-20 months & 13 months & 13 months & $8 \ddagger$ months & $8 \ddagger$ months \\
\hline & $\begin{array}{l}\text { paint } \\
\text { in period }\end{array}$ & fairly good & $\begin{array}{l}\text { some } \\
\text { somenth }\end{array}$ & $\begin{array}{l}\text { partly washed off } \\
14 \text { months }\end{array}$ & $\begin{array}{l}\text { almost entire } \\
14 \text { months }\end{array}$ & fair amount & badly eroded & slightly eroded & $\begin{array}{l}\text { badly eroded } \\
6 \text { to }\end{array}$ & badly eroded \\
\hline \multirow[t]{3}{*}{ v } & & fair an & & & & & & & & \\
\hline & $\begin{array}{l}\text { Growth } \\
\text { in period }\end{array}$ & $\begin{array}{l}\text { farr amount } \\
6 \text { weeks }\end{array}$ & 6 weeks & $\begin{array}{c}\text { abundant } \\
\text { from } 6 \text { weeks }\end{array}$ & $\begin{array}{l}\text { abundant } \\
\text { from } 6 \text { weeks }\end{array}$ & $\begin{array}{l}\text { slight } \\
\text { from one month }\end{array}$ & $\begin{array}{l}\text { little to much } \\
4 \text { to } 14 \frac{1}{2} \text { weeks }\end{array}$ & $\begin{array}{l}\text { little to much } \\
4 \text { to } 14 t \text { weeks }\end{array}$ & - & - \\
\hline & $\begin{array}{l}\text { paint } \\
\text { in period }\end{array}$ & $\begin{array}{l}\text { good } \\
14 \text { months }\end{array}$ & $\begin{array}{c}\text { some } \\
14 \text { months }\end{array}$ & $\begin{array}{l}\text { little to } \frac{1}{1} \text { eroded } \\
14 \text { months }\end{array}$ & $\begin{array}{l}\text { almost entire } \\
14 \text { months }\end{array}$ & $\begin{array}{c}\text { eaten away } \\
20-28 \text { months }\end{array}$ & $\begin{array}{l}\text { good } \\
91 \text { months }\end{array}$ & $\begin{array}{l}\text { good } \\
91 \text { months }\end{array}$ & & \\
\hline \multirow[t]{4}{*}{ VI } & Growth & slight & much & slight & abundant & abundant & slight & slight & & \\
\hline & in period & 6 weeks & 14 months & 9 weeks & 14 months & $6-9$ months & $9+$ months & 91 months & - & - \\
\hline & $\begin{array}{l}\text { paint } \\
\text { in period }\end{array}$ & $\begin{array}{l}\text { little left } \\
14 \text { months }\end{array}$ & $\begin{array}{l}\text { some } \\
14 \text { months }\end{array}$ & $\begin{array}{l}\text { almost all eroded } \\
14 \text { months }\end{array}$ & $\begin{array}{l}\text { trace to } \$ \text { eroded } \\
14 \text { months }\end{array}$ & $\begin{array}{l}\text { eroding in } 12 \\
\text { none left }\end{array}$ & $\begin{array}{l}\text { eroded } \\
6-9 \text { months }\end{array}$ & mostly eroded & & \\
\hline & & & & & & 28-31 months & & & & \\
\hline \multirow[t]{2}{*}{ VII } & Growth & $\begin{array}{l}\text { fair amount } \\
6 \text { weeks }\end{array}$ & abundant & $\begin{array}{l}\text { abundant } \\
6 \text { weeks }\end{array}$ & abundant & almost eaten away & abundant & abundant & fair amount & fair amount \\
\hline & & 6 weeks & 6 weeks & 6 weeks & 6 weeks & 20 months & 4-14ł weeks & 4-14t weeks & 5 ł weeks & $5 ł$ weeks \\
\hline
\end{tabular}




\begin{tabular}{|c|c|c|c|c|c|c|c|c|c|c|}
\hline VIII & $\begin{array}{l}\text { Growth } \\
\text { in period } \\
\text { paint } \\
\text { in period }\end{array}$ & $\begin{array}{l}\text { fair amount } \\
6 \text { weeks } \\
\text { little left } \\
14 \text { months }\end{array}$ & $\begin{array}{l}\text { abundant } \\
6 \text { weeks } \\
\text { some } \\
14 \text { months }\end{array}$ & $\begin{array}{c}\text { fair amount } \\
\text { from } 6 \text { weeks } \\
\text { trace } \\
14 \text { months }\end{array}$ & $\begin{array}{c}\text { fair amount } \\
\text { from } 6 \text { weeks } \\
\text { trace } \\
14 \text { months }\end{array}$ & $\begin{array}{l}\text { abundant } \\
1 \text { to } 23 \text { months } \\
\text { eroded or eaten } \\
12-20 \text { months }\end{array}$ & $\begin{array}{l}\text { slight } \\
\text { 3 to } 6 \text { months } \\
\text { mostly eroded } \\
3 \text { to } 6 \text { months }\end{array}$ & $\begin{array}{l}\text { slight } \\
3+\text { to } 6 \text { months } \\
\text { eroding badly } \\
9 \text { months }\end{array}$ & $\begin{array}{c}\text { fair amount } \\
12 \ddagger \text { weeks } \\
\text { badly eroded } \\
12 \ddagger \text { weeks }\end{array}$ & $\begin{array}{c}\text { fair amount } \\
12 \text { weeks } \\
\text { somewhat eroded } \\
12 \downarrow \text { weeks }\end{array}$ \\
\hline IX & $\begin{array}{l}\text { Growth } \\
\text { in period } \\
\text { paint } \\
\text { in period }\end{array}$ & - & - & - & - & $\begin{array}{l}\text { fair amount } \\
\text { one month } \\
\text { almost entire } \\
28 \text { months }\end{array}$ & $\begin{array}{l}\text { much } \\
\text { one month } \\
\text { good } \\
9 \frac{1}{2} \text { months }\end{array}$ & $\begin{array}{l}\text { much } \\
\text { one month } \\
\text { good } \\
9 \ddagger \text { months }\end{array}$ & $\begin{array}{l}\text { fair amount } \\
5 \pm \text { weeks } \\
\text { good } \\
25 \text { weeks }\end{array}$ & $\begin{array}{c}\text { fair amount } \\
5 \notin \text { weeks } \\
\text { good } \\
25 \text { weeks }\end{array}$ \\
\hline $\mathrm{x}$ & $\begin{array}{l}\text { Growth } \\
\text { in period } \\
\text { paint } \\
\text { in period }\end{array}$ & - & - & - & - & $\begin{array}{l}\text { abundant } \\
2 \text { to } 6 \text { months } \\
\text { almost entire } \\
28 \text { months : good } \\
\text { where not eaten } \\
42 \ddagger \text { months }\end{array}$ & $\begin{array}{l}\text { fair amount } \\
\text { one month } \\
\text { slightly eroded } \\
3 \ddagger \text { to } 9 \text { months }\end{array}$ & $\begin{array}{l}\text { fair amount } \\
\text { one month } \\
\text { good } \\
9 \text { months }\end{array}$ & - & $\begin{array}{l}\text { fair amount } \ddagger \\
5 t \text { weeks } \\
\text { good } \\
8 \text { months }\end{array}$ \\
\hline$X I$ & $\begin{array}{l}\text { Growth } \\
\text { in period } \\
\text { paint } \\
\text { in period }\end{array}$ & - & - & - & - & $\begin{array}{l}\text { abundant } \\
9-12 \text { months } \\
\text { washed away } \\
12 \text { months }\end{array}$ & $\begin{array}{c}\text { slight } \\
9 \text { months } \\
\text { badly eroded } \\
3 \downarrow \text { to } 9 \text { months }\end{array}$ & $\begin{array}{l}\text { slight } \\
9 \text { months } \\
\text { eroded badly } \\
9 \text { months }\end{array}$ & - & - \\
\hline XII & $\begin{array}{l}\text { Growth } \\
\text { in period } \\
\text { paint } \\
\text { in period }\end{array}$ & - & - & - & - & $\begin{array}{l}\text { abundant } \\
9-12 \text { months } \\
\text { entirely eroded } \\
20-28 \text { months }\end{array}$ & $\begin{array}{c}\text { slight } \\
14 \text { weeks } \\
\text { badly eroded } \\
14 ! \text { weeks. }\end{array}$ & $\begin{array}{c}\text { slight } \\
\text { 14t weeks } \\
\text { badly eroded } \\
14 \ddagger \text { weeks }\end{array}$ & - & - \\
\hline XV & $\begin{array}{l}\text { Growth } \\
\text { in period } \\
\text { paint } \\
\text { in period }\end{array}$ & - & - & - & - & - & - & - & $\begin{array}{c}\text { slight } \\
5 \downarrow \text { weeks } \\
\text { badly eroded } \\
5 \ddagger \text { to } 12 \downarrow \text { weeks }\end{array}$ & $\begin{array}{c}\text { slight } \\
5+\text { weeks } \\
\text { badly eroded } \\
5 \neq \text { to } 12 \$ \text { weeks }\end{array}$ \\
\hline XIII & and XIV & $\begin{array}{l}\text { XIII acquired } \\
\text { XIV acquired }\end{array}$ & $\begin{array}{l}\mathrm{h} \text { but beca } \\
\text { frowth in } 8\end{array}$ & $\begin{array}{l}\text { in } 14 \text { months } \\
\text { on one sheet }\end{array}$ & nd on 3 sheets $\mathrm{i}$ & $12 \frac{1}{\sharp}$ weeks. & & & & \\
\hline
\end{tabular}




\section{Results of Experiment $H$.}

It was found that the anti-fouling paint No. IV resisted growths so long as the paint remained on the shells, that is, during $8 \frac{1}{2}$ months only, in this experiment. This paint washed off the smoother faces of the shells much more rapidly than the rough face.

No. XIII, sheet copper, resisted growths so long as observed, i.e. ca. 14 months, but did not prevent marine growths occurring within even a few millimetres' distance.

No. XIV, sheet zinc, ${ }^{*}$ inhibited growth for only a short period; after only 8 to $12 \frac{1}{2}$ weeks in the sea a small proportion of the sheets used acquired a slight growth of Halichondria or hydroids.

No. IX, black varnish, became overgrown as soon as, and as much as, untreated shells, but remained in good condition longer than the other paints.

No. X, coal-tar on the rope, acquired growth as soon as, and apparently more profuse than, the clean shells.

No. XV, an ordinary grey paint, became washed off the shells to a great extent in only $5 \frac{1}{2}$ weeks and had disappeared after $12 \frac{1}{2}$ weeks.

No. VIII, red oxide, inhibited growth during 8 weeks so long as it remained on the shells. This paint was washed off the smoother faces of

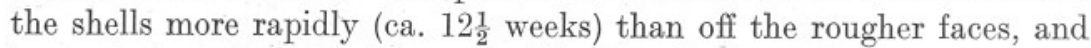
began to be overgrown (where it still adhered) after $12 \frac{1}{2}$ weeks.

In this situation erosion was more rapid than in corresponding experiments at the West Wharf and Cawsand Bay.

\section{Experiment $J$.}

This experiment has previously been partially recorded $(1,1914)$, but is included here briefly for comparison with others. The Cawsand Bay raft (see p. 380) was moored in the sea after being well coated with coal-tar on March 12th, 1912. Thirty-one weeks later, on October 15th, 1912, the raft was brought in and beached above high-water mark. Living Teredo norvegicus (not navalis as previously recorded) were taken from the boards of the raft on October 15th, and a re-examination was made for others on October 31st and November 2nd after the raft had been a fortnight out of water. On November 2 nd four large individuals were taken out of the wood and one was found to have cilia on the gill beating quite actively; the other three had recently died.

The largest specimen measured, fresh out of its burrow, was $19 \cdot 8 \mathrm{~cm}$. long. The largest boring was $28 \mathrm{~cm}$. long, and had a mean diameter of

* Zinc-coated buoys acquire a heavy growth of many kinds of organisms after only a relatively short period in the sea, namely, one to two years. The zine, however, becomes coated with a white substance, probably a zinc salt which has not been investigated and is apparently non-toxic or only slightly toxic. 
about $1 \mathrm{~cm}$. (see Fig. 18, below). The raft was made of common wood and was presumably pine. The general growth on the raft during 1912 was similar to that recorded in 1919 (see p. 396), and similar growth has been repeated during many seasons, therefore there is no doubt that coal-tar is of no value whatever for preventing marine growths or for preserving wood from the attacks of Teredo. On the other hand, Experiment G proves that coal-tar is a valuable agent for preserving wood from the attacks of gribble, i.e. Limnoria lignorum and Chelura terebrans, in English waters.

\section{Experiment $K$.}

A number of bathing rafts (usually three, sometimes four) are put out in the sea each year off Plymouth Hoe about the end of April and taken in again about the middle of the following October. It has been possible to make observations on these rafts over a number of years, owing to the courtesy of Mr. A. L. Bennetts of the Plymouth Corporation. The bottoms of these rafts are either well coated with two good coats of coal-tar or are thickly covered with pitch. Growth occurs quickly and luxuriantly on the bottoms and on the sides, comparable with that obtained on the Cawsand Bay raft; for example, Mytilus settles on the bottom and grows in situ each year to a size of

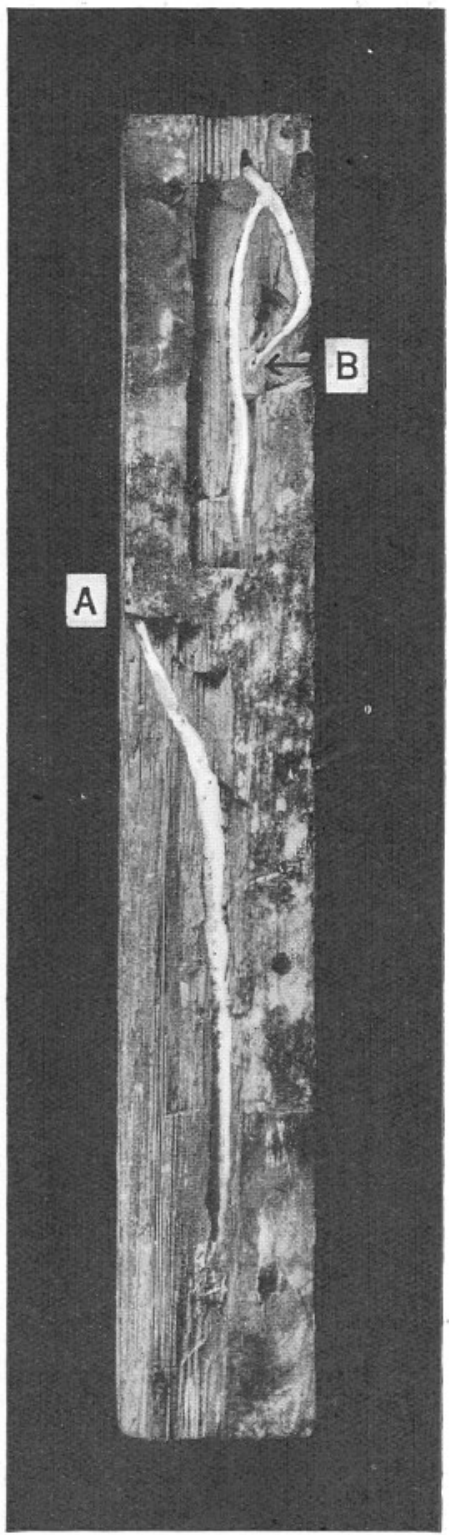

FIG. 18.- Photo of a piece of wood carved to expose two large Teredo borings from Experiment J, Cawsand Bay Raft, after 31 weeks' immersion in the sea. ( $\times$ ca. $\frac{2}{9}$.) (Photo by D. P. Wilson.)

A. The point of entry of one Teredo which bored to the middle of the wood and then continued its course in the middle. The end of the boring is not quite exposed.

B. The point of entry of another Teredo which, in order to avoid a nail, bored at first towards the side and then turned inwards, but found itself approaching the wetter and more external wood ; whereupon it abandoned the last part of the burrow, sealed it with a calcareous partition from the main burrow, and changed direction completely to bore down the middle. The end of the burrow is not lined with calcareous matter
and is not completely exposed. 
3 to $4 \mathrm{~cm}$. approximately; and in 1914 mature Ciona intestinalis grew up to $10.5 \mathrm{~cm}$. long, mature Ascidiella aspersa up to $5.9 \mathrm{~cm}$., Sycon coronatum to $8.2 \mathrm{~cm}$. long, carrying embryos; and other growths occurred comparable in general to that obtained on the Cawsand Bay raft (see p. 396). It is clear therefore that coal-tar and pitch are not deterrents to growth in the sea, and indeed when well-dried favour growth by offering at once a clean non-toxic surface for the organisms.

\section{Summary of Results from all ExPERIMENTS.}

The results obtained in all the experiments are collected together in Table XV, p. 422, and can now be considered. Experiments may be

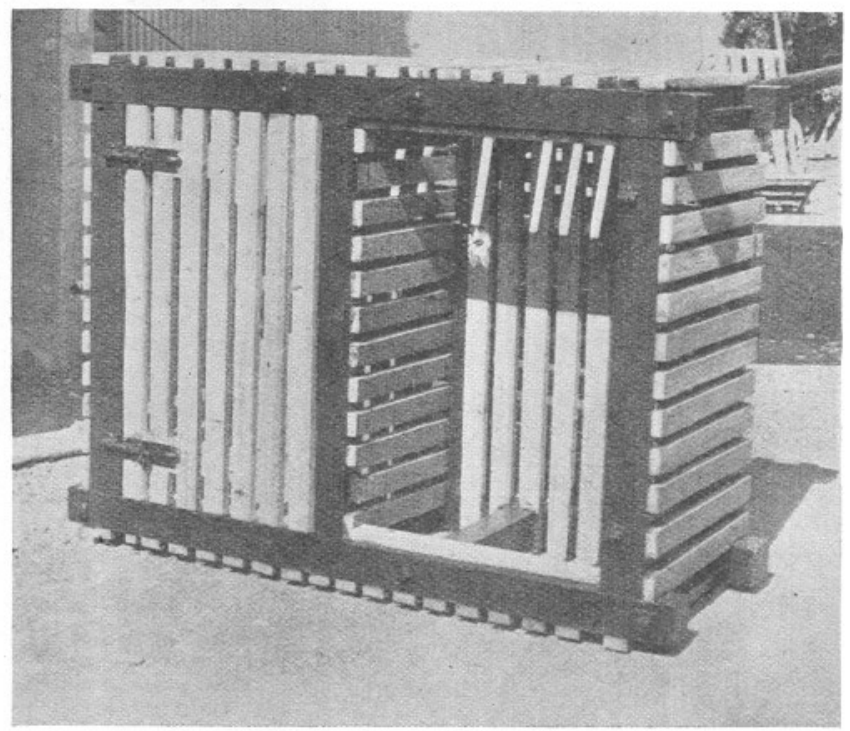

FIG. 19.-Photo of an upper view of a raft similar to, but three times as small as, the ore used in Cawsand Bay.

One lid has been removed to show the internal structure. Every piece of wood can be removed for observation of growth and can be replaced by a new piece without interfering with the structural basis of the raft. See Fig. 20 for under-surface view. This raft was used for experiments on rate of growth at Spitzbergen in 1921 (30). (Photo by A. J. Smith.)

referred to conveniently by letter to save repetition of the word " experiment."

It is clear from Table XV that the only paints having effective antifouling values are I, II, and IV. It is also manifest that the anti-fouling value depends upon the retention of the paint on a substratum (see especially the series of experiments on paints Nos. II, I, and XI).

All the paints are retained better on wood than on shells (compare $F$ and $G$ ) and better on the rougher face of the shells than on the smooth 
face (see D and E, G and H). On wood the paint was eroded less quickly in a situation subject to less erosion, as in $\mathrm{F}$, than in one subject to greater erosive influence as in A, B and C (compare also Table I, p. 382, and Table IX, p. 402, especially with regard to No. I paint). On shells there is an indication that erosion occurred roughly in proportion to the erosive effect of the sea-water in the different situations. Compare G in a relatively quiet situation with $\mathrm{D}$ and $\mathrm{E}$ where motion was continuous.

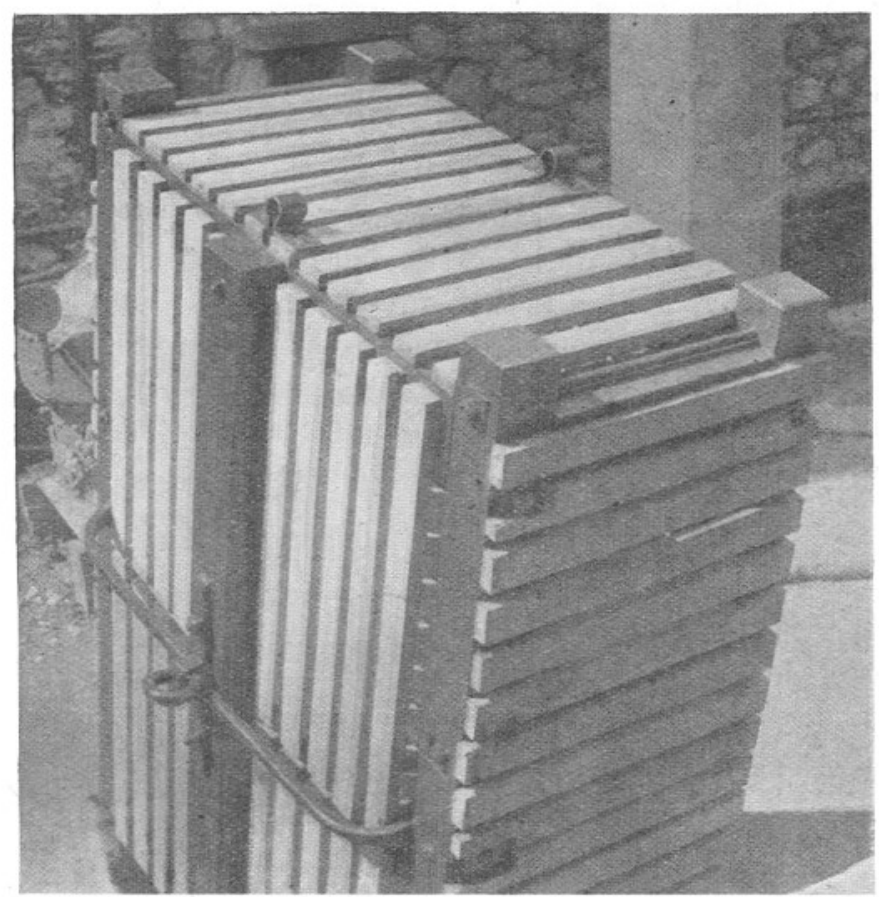

FIG. 20.-Photo of a raft similar to, but much smaller than, the one used in Cawsand Bay to show the under surface and side construction.

The bar of iron with loop for the swivelled shackle of the mooring-chain is also looped around the middle of each of the stout side-pieces which form a part of the basic skeletal structure of the raft. See also Fig. 19. The bolting of the basic parts is also shown. (Photo by A. J. Smith,

In H, however, No. IV paint eroded badly on the rougher face of the shells in 9 months, but it is possible that in this situation wave action at about the time of low water is exceptionally severe in winter, while it is probable that some rubbing occurred as well as water erosion.

It is significant that the proprietary anti-fouling paints VI and XI eroded rapidly and also permitted growth early, even when not eroded. See especially A and B, VI, for growth; and F, XI, for erosion.

The anti-corrosive substances III, V, and VIII all permit early growths, 
but while the latter eroded rapidly both on wood and shells the two former adhered to shells (and would presumably also adhere to iron) better than the best anti-fouling paint. On wood, however, No. V was rapidly eroded probably partly by gribble, whereas No. III remained in good condition and preserved the wood as long as any of the anti-fouling paints except No. II.

In its property of preserving wood (and probably also iron) coal-tar No. $\mathrm{X}$ was as efficient as the proprietary paint No. III, and more efficient than No. V, while so far as the observations were continued black varnish No. IX was shown to be equal in value as a preservative on wood to No. III and better than V.

Common paints such as XII and XV were shown to be rapidly eroded and to have only a slight preservative and anti-fouling value. Zinc, it was shown, might soon lose its toxic effect in the sea, but copper retained its anti-fouling property during the period of the experiment, but dissolved somewhat rapidly in the sea-water.

The most critical situation from an anti-fouling point of view is where a strong light plays on the paint, for No. II paint, which remained free from growth during at least 28 months in Experiment F, acquired some algal growth in 7 to 14 months in Experiment C.

\section{LIMITATIONS OF THE EXPERIMENTS.}

In order to compare the results obtained from the experiments herein recorded with those likely to be obtained in actual practice, i.e. on the bottoms of ships or other structures, it is necessary to compare the conditions under which the experiments were carried out with those occurring in actual practice.

\section{The Nature of the Surface covered by the Experimental} Substance.

In practice, iron ships, after being scraped and cleaned, are usually painted first with red oxide paint (such as No. VIII in the experiments), which is used as an (iron) anti-corrosive agent. When this coat is dry it is painted over sometimes with one or two coats of quick-drying antifouling paint, such as Nos. I, II, IV, VI, and XI in the foregoing experiments. Wooden ships after being scraped and cleaned-and more or less dried-are painted with the anti-fouling paint at once.

In the experiments the test-boards and shells were painted with two coats of anti-fouling paint, which were well dried on the same day or the day before the material was put in the sea. The treatment in the experiments with regard to painting is therefore comparable to, but better than, that given to iron vessels. With iron vessels the anti-fouling paint is usually directly applied on red oxide; and it is possible, and indeed 
probable, that the behaviour of the anti-fouling paints in the sea differs according to the nature of the underlying surface. In this respect there are three conditions to be considered, namely :-

(a) Anti-fouling paint on iron oxide over iron.

(b) Anti-fouling paint directly painted on to wood.

(c) Anti-fouling paint directly painted on to shells.

Experiments A, B, C, and $\mathrm{F}$ are of the $(b)$ type and the remaining experiments of the $(c)$ type. No experiments of the $(a)$ type were tried.

\section{Conditions Conducive to Erosion.}

The paint on the bottom of a ship is subjected to erosive effects in proportion to the speed of the ship and the period of time the boat is in motion. In Experiments A to $\mathrm{E}$ the experimental material was in effect buoyed and would be subject to almost continuous motion by the lifting motion of the waves as well as the slight pitch and roll of the buoy (i.e. the parallelopiped-shaped raft, $20 \times 5 \times 2$ feet). In Experiment $F$ the testboards were fixed and experienced no subjective motion. In Experiments $\mathrm{G}$ and $\mathrm{H}$ the material was also fixed with tarred rope, but in these cases the shells were liable to be, and were in instances, worked loose by wave action.

In Experiments $\mathrm{A}$ to $\mathrm{E}$ in Cawsand Bay the experimental material would be liable to erosion by slight tidal currents, and $\mathrm{H}$ at the Promenade Pier by similar tidal currents and wave action, especially at low water, while $\mathrm{F}$ and $\mathrm{G}$ at the West Wharf would only experience slight erosion due to the rise and fall of the tide and that due to slight wave action (in this protected situation) at low water.

Experiments A to $\mathrm{E}$ were therefore subject to relatively great erosive influences, but probably not so great as that experienced by even a 10-knot vessel; the painted surfaces in the other experiments would experience proportionately milder erosive action.

\section{Condition and Dryness of the Surfaces Painted.}

The surface of the bottom of an iron vessel which has been cleaned and scraped will vary from smooth to roughly pitted according to the number of times the bottom has been scraped and the degree of fouling experienced. The surface of the bottom of a wooden vessel will vary in a similar way, but will become more uneven than that of an iron ship.

In Experiments A, B, C, and F the wood was glass-papered to a smooth but not polished surface; and in the shell experiments the inner face of each shell is of a polished smoothness, while the outer face is roughened with fine decussations, except in some of the convex valves which might be smooth-worn on the crown of the shell. 
In all the experiments the experimental material was in a dry condition when painted, whereas when ships are painted under economic conditions the bottom is liable to be wet or damp in rainy or damp weather, or when docking is carried out hastily.

Thus on the whole the experimental paints would be applied more efficiently than under economic conditions, and to a variety of surfaces roughly comparable to those occurring on the bottoms of ships, but would be subject to less water erosion than on even slow-moving vessels (say, $10 \mathrm{knots}$ ) if such vessels are in fairly continuous translation.

\section{PART II. CHEMICAL INVESTIGATIONS.}

During the course of these experiments and observations the question arose during the concurrent investigation by the writer of the cause of unusual oyster mortality (14 and 15, 1921, 1923-24) as to what order of concentration of arsenic and copper particularly was likely to be poisonous to oysters and other marine animals. Fortunately, samples of paints which had been in the sea a considerable time while remaining poisonous were still available from the experiments herein described.

As it was possible to derive valuable information regarding the resistance of marine animals to poisons from chemical analyses of paints which $(a)$ retained their poisonous properties in the sea and $(b)$ were just losing their poisonous properties and beginning to be overgrown, the assistance of the Government Chemist was asked for and happily obtained for making a few critical analyses.

It is necessary to point out that a thorough chemical and biological study of the question was not contemplated in this research. In order to study the problem in such a way it would be necessary to know all the chemical ingredients used in the manufacture of the paints, but as the chief substances tested were proprietary articles, which are of great economic value, it was manifestly impossible to obtain the information.

The chemical investigations in these experiments are therefore limited to :-

(1) The analyses of three anti-fouling paints after exposure to seawater and retention of anti-fouling property for 19 months.

(2) The analyses of two of the same paints as in (1) after exposure to sea-water on test-boards for $42 \frac{1}{2}$ months, when the paints had either lost, or were apparently just about to lose, toxicity to marine animals.

(3) The analyses of samples of two original paints (the same as in (2)) from the original paint-can. 
These analyses were made in the Government Laboratory by the Government Chemist and his staff, to all of whom we are indebted for the resultant general information.

\section{Analyses of three Paints which Retatned Poisonous Properties after Remaining 19 Months in the Sea.}

Three of the shells used in Experiment G put out in the sea on August 28th, 1919, were collected from the West Wharf, Millbay Docks, Plymouth, on April 22nd, 1921, and forwarded the same day to the Government Chemist for chemical analysis of the paint remaining on the shells. At this time most of the paint on the smoother face of the shells had been washed away, but where the paint remained there was little growth other than Balanus in I and IV, but none on II, although good growth occurred on adjacent areas of the shell denuded of paint. (See notes to Table XIII, p. 415.)

Thus on this date paints I and IV were still toxic to most marine animals, and paint No. II was still poisonous. The Government Chemist reported $(\mathbf{1 5}, 1924$, p. 41) that "The paints were scraped off with as little of the shell matter as possible and give the following results :-

\begin{tabular}{|c|c|c|c|c|c|c|}
\hline $\begin{array}{c}\text { Lab. No. } \\
32\end{array}$ & $\begin{array}{l}\text { Paint. } \\
\text { IV }\end{array}$ & $\begin{array}{l}\text { Colour. } \\
\text { Red }\end{array}$ & $\begin{array}{l}\text { Lead. } \\
\text { Absent }\end{array}$ & $\begin{array}{c}\text { Zinc. } \\
\text { per cent. } \\
0.95\end{array}$ & $\begin{array}{c}\text { Copper } \\
\text { per cent. } \\
5 \cdot 79\end{array}$ & $\begin{array}{c}\text { Arsenic as } \\
\mathrm{As}_{4} \mathrm{O}_{6} \\
\text { per cent. } \\
0.01\end{array}$ \\
\hline 33 & I & Red & Absent & $0 \cdot 85$ & (cuprous) & 0.01 \\
\hline 34 & II & Green & Absent & $0 \cdot 04$ & $\begin{array}{c}16.56 \\
\text { (cupric) }\end{array}$ & $2 \cdot 60$ \\
\hline
\end{tabular}

No evidence of Mercury nor of Barium was obtained in any of the paints, but Nos. 32 and 33 contained large proportions of iron."

It is clear from these analyses that the paints I and IV are very much alike in constitution as in behaviour (see Table XV, p. 422) but contain very much less copper and arsenic than No. II. The combination of the metals zinc, copper, and arsenic in these paints with the respective percentages of approximately 1.0 zinc, 6 to 8 (cuprous) copper, and 0.01 per cent arsenic is one which is just approaching the limit of toxicity in seawater. This is a valuable result, even though the actual chemical constitution of the original materials is unknown.

The high percentage of cupric copper and arsenic remaining in paint II is sufficient explanation of the retained toxicity and a tribute to the efficiency of the matrix in this paint after 19 months' exposure on a shell surface in the sea. 


\section{Analyses of Paints on Test-Boards after about $3 \frac{1}{2}$ Years IN THE SEA.}

The paints II and IV on the test-boards used in Experiment F were analysed after remaining in the sea about $3 \frac{1}{2}$ years. The condition of these two test-boards with regard to overgrowth is given in detail in the section beginning on p. 410, and is depicted in Fig. 12, p. 404, and Fig. 13, p. 405 .

In the case of No. IV test-board, two areas of paint were scraped off and analysed. Both these areas had undoubtedly lost toxicity and were covered with living organisms when taken from the sea (see Fig. 12). The zinc-copper-arsenic percentage in these two samples of paint had been reduced greatly below that found to be near the limit of toxicity in the preceding sample, and had doubtless been non-toxic for some time, as may be also adjudged especially from the size of the barnacles (Balanus) which were growing on the analysed paint.

The condition with regard to overgrowths on the areas of paint, A to D, analysed from the front face of test-board II were as follows, but see also Fig. 12, p. 404.

\section{Site.}

Area A Around the fixing nail 10 to 18.4 inches from the top.

Area B $\begin{aligned} & 4 \cdot 5 \\ & \text { from }\end{aligned}$ to $8 \cdot 8$ inches Area C $\begin{aligned} & 10 \cdot 5 \\ & \text { from }\end{aligned}$ to $14 \cdot 7$ inches
Region.

In the upper middle region of the board.
Growth.

Covered in part with a growth of the hydroid Obelia and with a few borings of gribble in a crack in the wood.

the bottom of with 3 large and a few the board small borings of gribble, i.e. Limnoria or Chelura.

the bottom of No growth observable. the board, i.e. in the lower half.

Area D $5 \cdot 6$ to $9 \cdot 8$ inches from the top of the No growth observable. board.

The bottom of the board was covered with a growth of Diplosoma, Umbonula, and Halichondria up to a height of 5 or 6 inches from the lower edge ; this growth probably encroached slightly on the lower part of area $B$, which was scraped for chemical analysis.

The results of the analyses of the samples of paints scraped from areas A to $\mathrm{D}$ are given in the following report by the Government Chemist with a discussion on the significance of the figures obtained, together with analyses of the original paints from the paint-can. 
The Government Chemist's Report on Chemical Analyses.

"REPORT ON THE EXAMINATION OF TWO SAMPLES OF ANTIFOULING PAINT RECEIVED FROM DR. ORTON ON 15TH MARCH, 1923, AND OF THE PAINT REMAINING ON AREAS OF TWO WOODEN BOARDS TO WHICH THESE PAINTS HAD BEEN APPLIED WITH DIFFERING TOXIC

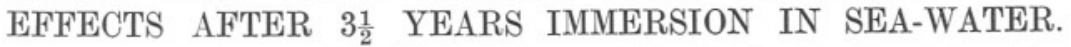

The paints were described as :-

Lab. No. 323. 1. (Green paint)

Lab. No. 324. 2. (Brown paint)

and gave the following results on analysis :-

TABLE 1.

Analyses of No. II and No. IV Original Paints.

Volatile matter (turpentine substitute)

Oil

Oxidised oil and varnish gums

Silica and silicates

Lead oxide

Arsenious oxide

Cupric oxide

Cuprous oxide

Iron oxide

Zine oxide

Calcium oxide

Carbon dioxide

Phosphoric pentoxide

Magnesium oxide

Sulphuric anhydride

Green
per cent.

(Reddish) brown

per cent.

per cent.

$18 \cdot 7$

$21 \cdot 6$

$8 \cdot 6$

$15 \cdot 9$

$1 \cdot 2$

$10 \cdot 5$

$0 \cdot 1$

$5 \cdot 6$

$5 \cdot 0$

$14 \cdot 8$

nil

$0 \cdot 4$

0.8

nil

0.2

nil
$11 \cdot 8$

$15 \cdot 4$

$8 \cdot 6$

0.5

$4 \cdot 6$

$9 \cdot 3$

$0 \cdot 2$

$0 \cdot 2$

$8 \cdot 3$

nil

$8 \cdot 6$

0.9

$5 \cdot 8$

matter (by difference)

$\underline{\underline{100 \cdot 0}}$

nil

nil

$\underline{\underline{100 \cdot 0}}$

In the green paint the copper appears to be present partly as insoluble basic sulphate (and some of the lime might also be linked up with this) and partly as aceto-arsenite of copper (Scheeles green). The calciumoxide is in combination with the carbon dioxide and with part of the sulphuric anhydride. It is impossible to give the exact composition of such a mixture.

In the case of the brown paint the copper is present in the form of red cuprous oxide and the calcium and magnesium oxides are in combination with the carbon dioxide forming carbonates.

The paint on the boards was very thin and only small quantities were obtained from the areas scraped. There was not sufficient material, therefore, for complete analyses. The most important constituents have 
been determined but the results are complicated by the fact that silicious material, carbonates, sodium salts, etc., have been deposited in the paint. Before scraping off the samples all organic growth was removed together with any incrustation that obviously did not belong to the paint. In the case of the brown board sample A was taken from a place competely overgrown, while the area sampled for B was fairly clean except for five or six barnacles.

Four areas of the green-painted board were marked A, B, C, and D by Dr. Orton, who stated that 'the part A has a growth of hydroids roughly within the circle,' and 'parts B, C, and D are apparently all just losing toxicity.'

The results of the analysis are as follows :-

Table 2.

Analyses of Paint Scrapings from Test-Boards II and IV. EXPERIMENT F,

\section{(a) Green board (II)}

Insoluble
in acid. $\left\{\begin{array}{c}\text { Oxidised oil, wood } \\ \text { and organic matter } \\ \text { Mineral matter, silica } \\ \text { and silicates }\end{array}\right.$ Cupric oxide

Iron oxide

Zinc oxide

Calcium oxide

Magnesium oxide

Arsenious oxide

Phosphorous pentoxide

Undetermined $-\mathrm{CO}_{2}$, chlorides, sulphates, moisture, soluble organic matter, and sodium salts

\section{(b) Brown board (IV)}

\begin{tabular}{|c|c|c|c|}
\hline $\begin{array}{c}\text { Partly } \\
\text { covered by } \\
\text { a growth } \\
\text { of hydroid. } \\
\text { A } \\
\% \\
14 \cdot 1\end{array}$ & $\begin{array}{c}\text { Bored by } \\
\text { gribble and } \\
\text { slightly } \\
\text { overgrown. } \\
\text { B } \\
\% \\
14 \cdot 5\end{array}$ & $\begin{array}{c}\text { No } \\
\text { growth. } \\
\text { C } \\
\% \\
12 \cdot 1\end{array}$ & $\begin{array}{c}\text { No } \\
\text { growth. } \\
\text { D } \\
\% \\
14 \cdot 4\end{array}$ \\
\hline $30 \cdot 8$ & $34 \cdot 8$ & $28 \cdot 8$ & $11 \cdot 2$ \\
\hline $4 \cdot 0$ & $2 \cdot 2$ & $7 \cdot 5$ & $15 \cdot 2$ \\
\hline $4 \cdot 5$ & $6 \cdot 3$ & $5 \cdot 0$ & $2 \cdot 4$ \\
\hline $0 \cdot 2$ & $0 \cdot 3$ & $0 \cdot 4$ & $0 \cdot 2$ \\
\hline $22 \cdot 6$ & $30 \cdot 4$ & $11 \cdot 2$ & $8 \cdot 5$ \\
\hline $1 \cdot 4$ & $1 \cdot 6$ & $1 \cdot 8$ & 0.9 \\
\hline $0 \cdot 4$ & trace & $0 \cdot 7$ & $0 \cdot 7$ \\
\hline $0 \cdot 6$ & 0.5 & $0 \cdot 3$ & $0 \cdot 3$ \\
\hline $21 \cdot 4$ & $9 \cdot 4$ & $32 \cdot 2$ & $46 \cdot 2$ \\
\hline $100 \cdot 0$ & $100 \cdot 0$ & $100 \cdot 0$ & $100 \cdot 0$ \\
\hline
\end{tabular}

\begin{tabular}{|c|c|c|}
\hline & & \\
\hline Insoluble ( Oxidised oil,wood and organic matter & $17 \%$ & 16.5 \\
\hline in acid. $\left\{\begin{array}{l}\text { Mineral matter, silica and silicates } \\
\text { inter }\end{array}\right.$ & $16 \cdot 9$ & $\begin{array}{l}16 \cdot 5 \\
19 \cdot 3\end{array}$ \\
\hline Cuprous oxide & $0 \cdot 2$ & $0 \cdot 6$ \\
\hline Iron oxide & $16 \cdot 4$ & $16 \cdot 0$ \\
\hline Zinc oxide & 0.5 & $0 \cdot 6$ \\
\hline Calcium oxide & $24 \cdot 2$ & $19 \cdot 2$ \\
\hline Magnesium oxide & $2 \cdot 6$ & $2 \cdot 2$ \\
\hline Arsenious oxide & nil & $0 \cdot 05$ \\
\hline Phosphorous pentoxide & $0 \cdot 4$ & $0 \cdot 3$ \\
\hline $\begin{array}{l}\text { Undetermined }-\mathrm{CO}_{2} \text {, chlorides, sulphates, } \\
\text { moisture, soluble organic matter and } \\
\text { sodium salts }\end{array}$ & $21 \cdot 3$ & $25 \cdot 3$ \\
\hline & $100 \cdot 0$ & $100 \cdot 0$ \\
\hline
\end{tabular}


It will be seen that in both sets of samples there are notable increases in the proportions of silicious material and calcium oxide while in the samples from the green board the iron has unaccountably increased.

In order to obtain a better comparison of the main inorganic constituents of the scrapings with those of the original paints the basic constituents (including silica and silicates and arsenic) have been added together and worked out on a 100 per cent basis. The figures are as follows :-

\section{TABLe 3.}

Percentage of Basic Constituents (including Silica, Silicates, and Arsenious Oxide) in the Original Paints II and IV and in Samples exposed in the Sea for $3 \frac{1}{2}$ Years.

(a) Green board (II)

Basic constituents (includ-

Original
paint.

$\%$

ing silica and silicates) $31 \cdot 1$

Silica and silicates

Lead oxide

Arsenious oxide

Cupric oxide

Iron oxide

Zinc oxide

Calcium oxide

Magnesium oxide

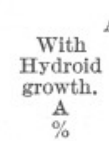

$63 \cdot 9$

Areas after $3 \frac{1}{1}$ years exposure in the sea.

$$
\begin{gathered}
\text { With } \\
\text { gribble } \\
\text { borings. } \\
\text { B } \\
\%
\end{gathered}
$$

$75 \cdot 5$

$46 \cdot 1$

nil

tce.

$2 \cdot 9$

$8 \cdot 3$

$0 \cdot 4$

$40 \cdot 2$

$2 \cdot 1$

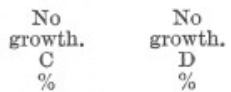

$55 \cdot 4$

$39 \cdot 0$

\begin{tabular}{rcccc}
$3 \cdot 9$ & $48 \cdot 2$ & $46 \cdot 1$ & $52 \cdot 1$ & $28 \cdot 7$ \\
$0 \cdot 3$ & nil & nil & nil & nil \\
$16 \cdot 1$ & $0 \cdot 6$ & tce. & $1 \cdot 2$ & $1 \cdot 7$ \\
$47 \cdot 5$ & $6 \cdot 3$ & $2 \cdot 9$ & $13 \cdot 5$ & $39 \cdot 0$ \\
$1 \cdot 3$ & $7 \cdot 0$ & $8 \cdot 3$ & $9 \cdot 1$ & $6 \cdot 0$ \\
$2 \cdot 6$ & $0 \cdot 3$ & $0 \cdot 4$ & $0 \cdot 7$ & $0 \cdot 6$ \\
$27 \cdot 6$ & $35 \cdot 4$ & $40 \cdot 2$ & $20 \cdot 1$ & $21 \cdot 7$ \\
$0 \cdot 7$ & $2 \cdot 2$ & $2 \cdot 1$ & $3 \cdot 3$ & $2 \cdot 3$ \\
\hline $100 \cdot 0$ & $100 \cdot 0$ & $\underline{100 \cdot 0}$ & $\underline{100 \cdot 0}$ & $\underline{100 \cdot 0}$ \\
\hline
\end{tabular}

(b) Brown board (IV)

Basic constituents (including silica and silicates)

Silica and silicates

Arsenious oxide

Cuprous oxide

Iron oxide

Zinc oxide

Calcium oxide

Magnesium oxide

\begin{tabular}{|c|c|c|}
\hline $\begin{array}{c}\text { Original } \\
\text { paint. } \\
\% \\
\%\end{array}$ & $\begin{array}{c}\text { Overgrown } \\
\text { area. } \\
\text { A } \\
\% \\
60.9\end{array}$ & $\begin{array}{c}\text { Overgrown } \\
\text { area. } \\
\text { B } \\
\% \\
57.9\end{array}$ \\
\hline $12 \cdot 8$ & $27 \cdot 8$ & $33 \cdot 2$ \\
\hline 0.5 & nil & $0 \cdot 1$ \\
\hline $27 \cdot 0$ & 0.4 & $1 \cdot 0$ \\
\hline $35 \cdot 2$ & $26 \cdot 9$ & $27 \cdot 7$ \\
\hline $1 \cdot 1$ & $0 \cdot 8$ & $1 \cdot 1$ \\
\hline $21 \cdot 3$ & $39 \cdot 8$ & $33 \cdot 1$ \\
\hline $2 \cdot 1$ & $4 \cdot 3$ & $3 \cdot 8$ \\
\hline $100 \cdot 0$ & $100 \cdot 0$ & $100 \cdot 0$ \\
\hline
\end{tabular}


The results from the green (arsenic) board are peculiar. Sample B contained the largest proportion of basic constituents and silica, i.e. 75.5 per cent, the bulk of this consisting of silica and silicates and calcium oxide.* Since practically all the arsenic and most of the copper have been washed out, this paint should have lost its toxicity to a greater extent than A which still contains $0 \cdot 6$ and $6 \cdot 3$ per cent respectively of arsenious oxide and copper oxide. Samples $\mathrm{C}$ and $\mathrm{D}$ should be more toxic than $\mathrm{A}$ and it will be seen that whereas in A and B there is an increase in the proportion of calcium oxide which is presumably due to shells* of minute organisms, the proportion in C and D is less than in the original paint, pointing to the paint surface still being obnoxious to the organisms. The proportion of basic constituents and silica in D is only $39 \cdot 0$ per cent as compared with 63.9 per cent in A.

The apparent increase in the iron content of the scrapings may have been caused by deposition of rust or some insoluble iron deposit from the sea water, or it may be due to the ferric oxide in the original paint being very much more resistant to the sea water than all the other constituents. of the paint.

In the case of the brown (copper) board it can be said that the cuprous. oxide has been almost completely washed out and there is little difference in the copper content on the area completely overgrown (A) and on the area only partially overgrown (B).

It is, however, practically impossible from the limited number of results to trace the changes which have occurred in the paints during exposure. The composition of the paint is affected on the one hand by removal of constituents, organic and inorganic, and on the other by addition of inorganic matter in the form of calcium carbonate and silicious. material derived either from the sea water or from organisms inseparable from the surface of the paint, or of organic matter, from the organisms. or from the underlying wood, which could not be separated from the scraped paint.

The results of the analysis of the paints on three shells which were given in the oyster mortality investigation report of 14th July, 1921, in terms of metallic copper and zinc may be stated, for comparison in terms. of the compounds found in the original paints as follows :-

$\begin{array}{lccccc}\text { Lab. No. } & \begin{array}{c}\text { No. of } \\ \text { paint. }\end{array} & \begin{array}{c}\text { Cuprous } \\ \text { oxide. } \\ \%\end{array} & \begin{array}{c}\text { Cupric } \\ \text { oxide. } \\ \%\end{array} & \begin{array}{c}\text { Zinc } \\ \text { oxide. } \\ \%\end{array} & \begin{array}{c}\text { Arsenious } \\ \text { oxide. } \\ \%\end{array} \\ 32 \text { (red) } & \text { IV } & 6 \cdot 52 & - & 1 \cdot 18 & 0 \cdot 01 \\ 33 \text { (red) } & \text { I } & 8 \cdot 91 & - & 1 \cdot 06 & 0 \cdot 01 \\ 34 \text { (green) } & \text { II } & - & 20 \cdot 71 & 0 \cdot 05 & 2 \cdot 60\end{array}$

* The excess of calcium oxide in this sample was probably derived from the encrusting Polyzoan on the lower part of area B (see p. 432). J. H. O. 
about $1 \mathrm{~cm}$. (see Fig. 18, below). The raft was made of common wood and was presumably pine. The general growth on the raft during 1912 was similar to that recorded in 1919 (see p. 396), and similar growth has been repeated during many seasons, therefore there is no doubt that coal-tar is of no value whatever for preventing marine growths or for preserving wood from the attacks of Teredo. On the other hand, Experiment G proves that coal-tar is a valuable agent for preserving wood from the attacks of gribble, i.e. Limnoria lignorum and Chelura terebrans, in English waters.

\section{Experiment $K$.}

A number of bathing rafts (usually three, sometimes four) are put out in the sea each year off Plymouth Hoe about the end of April and taken in again about the middle of the following October. It has been possible to make observations on these rafts over a number of years, owing to the courtesy of Mr. A. L. Bennetts of the Plymouth Corporation. The bottoms of these rafts are either well coated with two good coats of coal-tar or are thickly covered with pitch. Growth occurs quickly and luxuriantly on the bottoms and on the sides, comparable with that obtained on the Cawsand Bay raft; for example, Mytilus settles on the bottom and grows in situ each year to a size of

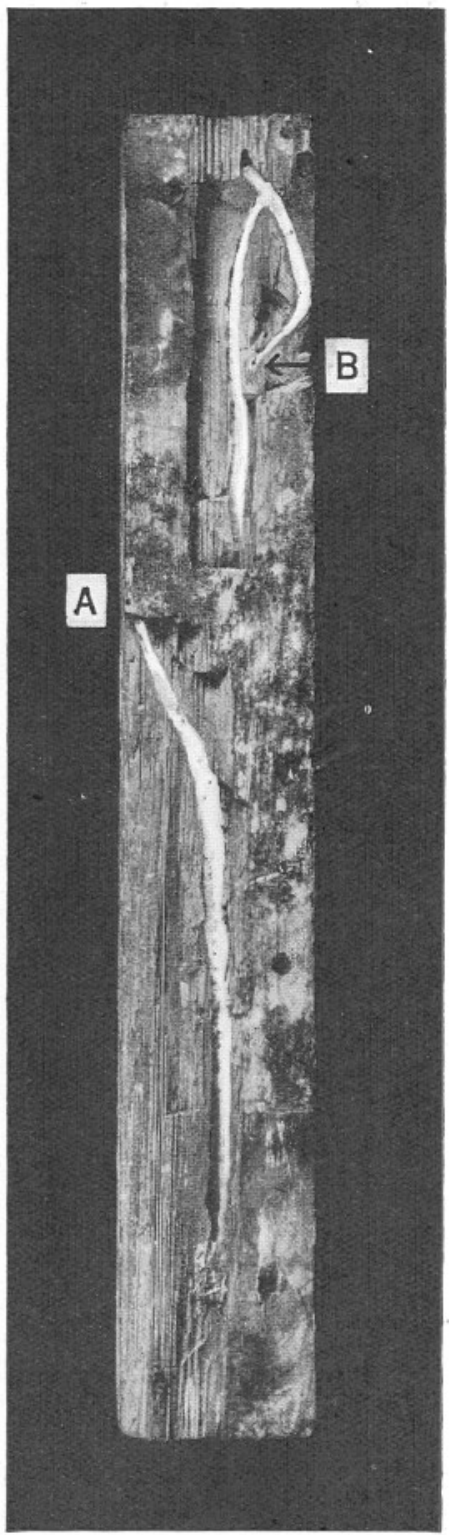

FIG. 18.- Photo of a piece of wood carved to expose two large Teredo borings from Experiment J, Cawsand Bay Raft, after 31 weeks' immersion in the sea. ( $\times$ ca. $\frac{2}{9}$.) (Photo by D. P. Wilson.)

A. The point of entry of one Teredo which bored to the middle of the wood and then continued its course in the middle. The end of the boring is not quite exposed.

B. The point of entry of another Teredo which, in order to avoid a nail, bored at first towards the side and then turned inwards, but found itself approaching the wetter and more external wood ; whereupon it abandoned the last part of the burrow, sealed it with a calcareous partition from the main burrow, and changed direction completely to bore down the middle. The end of the burrow is not lined with calcareous matter
and is not completely exposed. 
3 to $4 \mathrm{~cm}$. approximately; and in 1914 mature Ciona intestinalis grew up to $10.5 \mathrm{~cm}$. long, mature Ascidiella aspersa up to $5.9 \mathrm{~cm}$., Sycon coronatum to $8.2 \mathrm{~cm}$. long, carrying embryos; and other growths occurred comparable in general to that obtained on the Cawsand Bay raft (see p. 396). It is clear therefore that coal-tar and pitch are not deterrents to growth in the sea, and indeed when well-dried favour growth by offering at once a clean non-toxic surface for the organisms.

\section{Summary of Results from all ExPERIMENTS.}

The results obtained in all the experiments are collected together in Table XV, p. 422, and can now be considered. Experiments may be

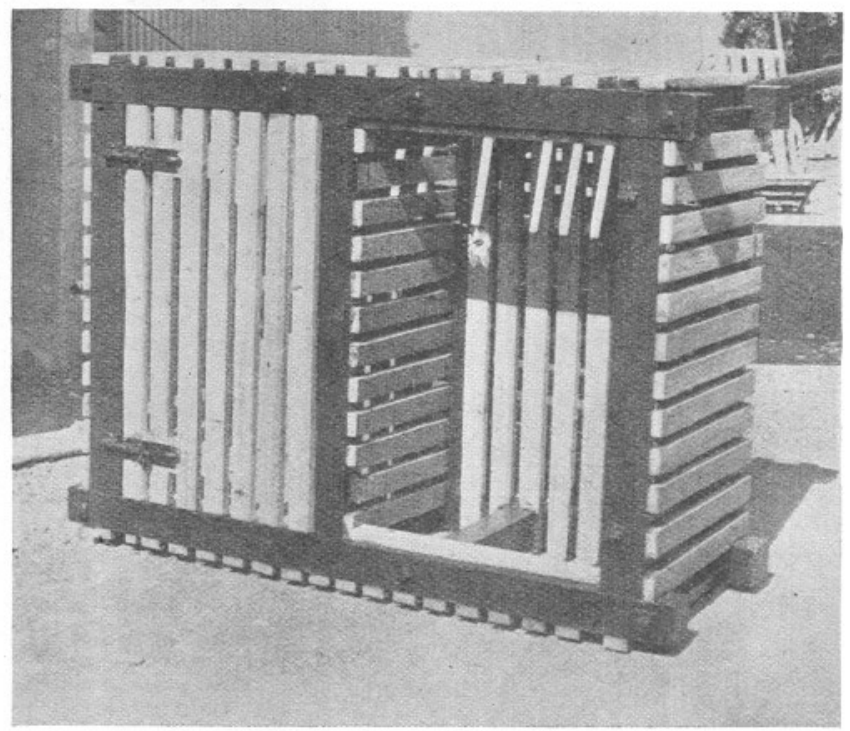

FIG. 19.-Photo of an upper view of a raft similar to, but three times as small as, the ore used in Cawsand Bay.

One lid has been removed to show the internal structure. Every piece of wood can be removed for observation of growth and can be replaced by a new piece without interfering with the structural basis of the raft. See Fig. 20 for under-surface view. This raft was used for experiments on rate of growth at Spitzbergen in 1921 (30). (Photo by A. J. Smith.)

referred to conveniently by letter to save repetition of the word " experiment."

It is clear from Table XV that the only paints having effective antifouling values are I, II, and IV. It is also manifest that the anti-fouling value depends upon the retention of the paint on a substratum (see especially the series of experiments on paints Nos. II, I, and XI).

All the paints are retained better on wood than on shells (compare $F$ and $G$ ) and better on the rougher face of the shells than on the smooth 
face (see D and E, G and H). On wood the paint was eroded less quickly in a situation subject to less erosion, as in $\mathrm{F}$, than in one subject to greater erosive influence as in A, B and C (compare also Table I, p. 382, and Table IX, p. 402, especially with regard to No. I paint). On shells there is an indication that erosion occurred roughly in proportion to the erosive effect of the sea-water in the different situations. Compare G in a relatively quiet situation with $\mathrm{D}$ and $\mathrm{E}$ where motion was continuous.

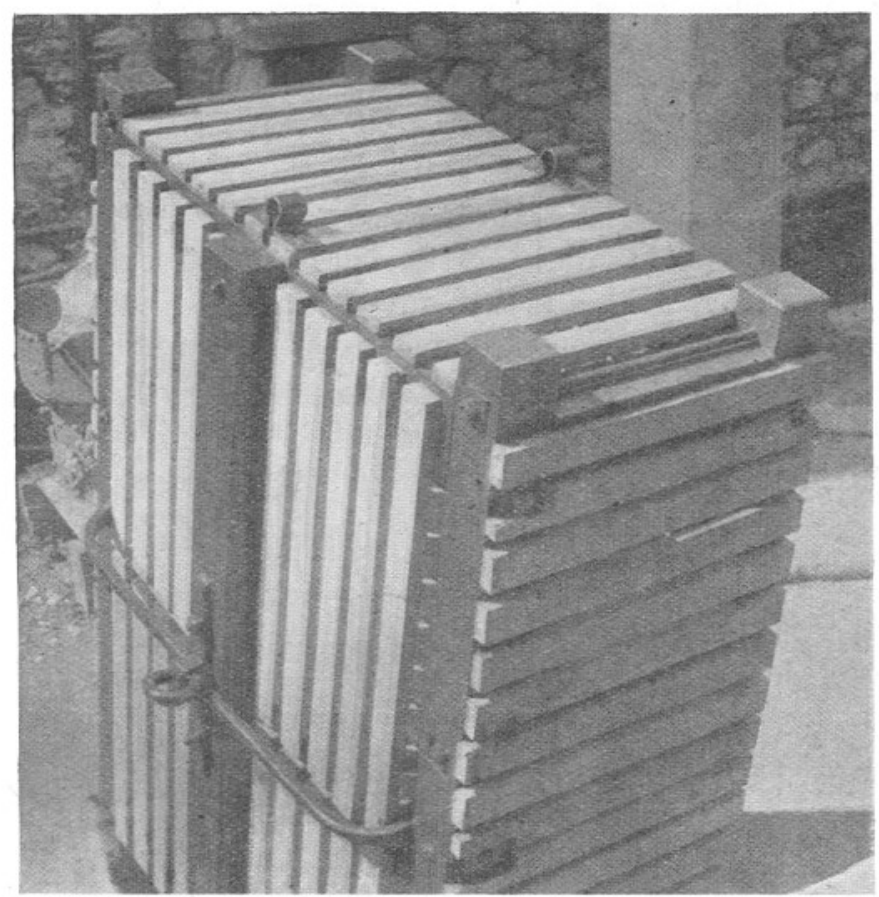

FIG. 20.-Photo of a raft similar to, but much smaller than, the one used in Cawsand Bay to show the under surface and side construction.

The bar of iron with loop for the swivelled shackle of the mooring-chain is also looped around the middle of each of the stout side-pieces which form a part of the basic skeletal structure of the raft. See also Fig. 19. The bolting of the basic parts is also shown. (Photo by A. J. Smith,

In H, however, No. IV paint eroded badly on the rougher face of the shells in 9 months, but it is possible that in this situation wave action at about the time of low water is exceptionally severe in winter, while it is probable that some rubbing occurred as well as water erosion.

It is significant that the proprietary anti-fouling paints VI and XI eroded rapidly and also permitted growth early, even when not eroded. See especially A and B, VI, for growth; and F, XI, for erosion.

The anti-corrosive substances III, V, and VIII all permit early growths, 
but while the latter eroded rapidly both on wood and shells the two former adhered to shells (and would presumably also adhere to iron) better than the best anti-fouling paint. On wood, however, No. V was rapidly eroded probably partly by gribble, whereas No. III remained in good condition and preserved the wood as long as any of the anti-fouling paints except No. II.

In its property of preserving wood (and probably also iron) coal-tar No. $\mathrm{X}$ was as efficient as the proprietary paint No. III, and more efficient than No. V, while so far as the observations were continued black varnish No. IX was shown to be equal in value as a preservative on wood to No. III and better than V.

Common paints such as XII and XV were shown to be rapidly eroded and to have only a slight preservative and anti-fouling value. Zinc, it was shown, might soon lose its toxic effect in the sea, but copper retained its anti-fouling property during the period of the experiment, but dissolved somewhat rapidly in the sea-water.

The most critical situation from an anti-fouling point of view is where a strong light plays on the paint, for No. II paint, which remained free from growth during at least 28 months in Experiment F, acquired some algal growth in 7 to 14 months in Experiment C.

\section{LIMITATIONS OF THE EXPERIMENTS.}

In order to compare the results obtained from the experiments herein recorded with those likely to be obtained in actual practice, i.e. on the bottoms of ships or other structures, it is necessary to compare the conditions under which the experiments were carried out with those occurring in actual practice.

\section{The Nature of the Surface covered by the Experimental} Substance.

In practice, iron ships, after being scraped and cleaned, are usually painted first with red oxide paint (such as No. VIII in the experiments), which is used as an (iron) anti-corrosive agent. When this coat is dry it is painted over sometimes with one or two coats of quick-drying antifouling paint, such as Nos. I, II, IV, VI, and XI in the foregoing experiments. Wooden ships after being scraped and cleaned-and more or less dried-are painted with the anti-fouling paint at once.

In the experiments the test-boards and shells were painted with two coats of anti-fouling paint, which were well dried on the same day or the day before the material was put in the sea. The treatment in the experiments with regard to painting is therefore comparable to, but better than, that given to iron vessels. With iron vessels the anti-fouling paint is usually directly applied on red oxide; and it is possible, and indeed 
probable, that the behaviour of the anti-fouling paints in the sea differs according to the nature of the underlying surface. In this respect there are three conditions to be considered, namely :-

(a) Anti-fouling paint on iron oxide over iron.

(b) Anti-fouling paint directly painted on to wood.

(c) Anti-fouling paint directly painted on to shells.

Experiments A, B, C, and $\mathrm{F}$ are of the $(b)$ type and the remaining experiments of the $(c)$ type. No experiments of the $(a)$ type were tried.

\section{Conditions Conducive to Erosion.}

The paint on the bottom of a ship is subjected to erosive effects in proportion to the speed of the ship and the period of time the boat is in motion. In Experiments A to $\mathrm{E}$ the experimental material was in effect buoyed and would be subject to almost continuous motion by the lifting motion of the waves as well as the slight pitch and roll of the buoy (i.e. the parallelopiped-shaped raft, $20 \times 5 \times 2$ feet). In Experiment $F$ the testboards were fixed and experienced no subjective motion. In Experiments $\mathrm{G}$ and $\mathrm{H}$ the material was also fixed with tarred rope, but in these cases the shells were liable to be, and were in instances, worked loose by wave action.

In Experiments $\mathrm{A}$ to $\mathrm{E}$ in Cawsand Bay the experimental material would be liable to erosion by slight tidal currents, and $\mathrm{H}$ at the Promenade Pier by similar tidal currents and wave action, especially at low water, while $\mathrm{F}$ and $\mathrm{G}$ at the West Wharf would only experience slight erosion due to the rise and fall of the tide and that due to slight wave action (in this protected situation) at low water.

Experiments A to $\mathrm{E}$ were therefore subject to relatively great erosive influences, but probably not so great as that experienced by even a 10-knot vessel; the painted surfaces in the other experiments would experience proportionately milder erosive action.

\section{Condition and Dryness of the Surfaces Painted.}

The surface of the bottom of an iron vessel which has been cleaned and scraped will vary from smooth to roughly pitted according to the number of times the bottom has been scraped and the degree of fouling experienced. The surface of the bottom of a wooden vessel will vary in a similar way, but will become more uneven than that of an iron ship.

In Experiments A, B, C, and F the wood was glass-papered to a smooth but not polished surface; and in the shell experiments the inner face of each shell is of a polished smoothness, while the outer face is roughened with fine decussations, except in some of the convex valves which might be smooth-worn on the crown of the shell. 
In all the experiments the experimental material was in a dry condition when painted, whereas when ships are painted under economic conditions the bottom is liable to be wet or damp in rainy or damp weather, or when docking is carried out hastily.

Thus on the whole the experimental paints would be applied more efficiently than under economic conditions, and to a variety of surfaces roughly comparable to those occurring on the bottoms of ships, but would be subject to less water erosion than on even slow-moving vessels (say, $10 \mathrm{knots}$ ) if such vessels are in fairly continuous translation.

\section{PART II. CHEMICAL INVESTIGATIONS.}

During the course of these experiments and observations the question arose during the concurrent investigation by the writer of the cause of unusual oyster mortality (14 and 15, 1921, 1923-24) as to what order of concentration of arsenic and copper particularly was likely to be poisonous to oysters and other marine animals. Fortunately, samples of paints which had been in the sea a considerable time while remaining poisonous were still available from the experiments herein described.

As it was possible to derive valuable information regarding the resistance of marine animals to poisons from chemical analyses of paints which $(a)$ retained their poisonous properties in the sea and $(b)$ were just losing their poisonous properties and beginning to be overgrown, the assistance of the Government Chemist was asked for and happily obtained for making a few critical analyses.

It is necessary to point out that a thorough chemical and biological study of the question was not contemplated in this research. In order to study the problem in such a way it would be necessary to know all the chemical ingredients used in the manufacture of the paints, but as the chief substances tested were proprietary articles, which are of great economic value, it was manifestly impossible to obtain the information.

The chemical investigations in these experiments are therefore limited to :-

(1) The analyses of three anti-fouling paints after exposure to seawater and retention of anti-fouling property for 19 months.

(2) The analyses of two of the same paints as in (1) after exposure to sea-water on test-boards for $42 \frac{1}{2}$ months, when the paints had either lost, or were apparently just about to lose, toxicity to marine animals.

(3) The analyses of samples of two original paints (the same as in (2)) from the original paint-can. 
These analyses were made in the Government Laboratory by the Government Chemist and his staff, to all of whom we are indebted for the resultant general information.

\section{Analyses of three Paints which Retatned Poisonous Properties after Remaining 19 Months in the Sea.}

Three of the shells used in Experiment G put out in the sea on August 28th, 1919, were collected from the West Wharf, Millbay Docks, Plymouth, on April 22nd, 1921, and forwarded the same day to the Government Chemist for chemical analysis of the paint remaining on the shells. At this time most of the paint on the smoother face of the shells had been washed away, but where the paint remained there was little growth other than Balanus in I and IV, but none on II, although good growth occurred on adjacent areas of the shell denuded of paint. (See notes to Table XIII, p. 415.)

Thus on this date paints I and IV were still toxic to most marine animals, and paint No. II was still poisonous. The Government Chemist reported $(\mathbf{1 5}, 1924$, p. 41) that "The paints were scraped off with as little of the shell matter as possible and give the following results :-

\begin{tabular}{|c|c|c|c|c|c|c|}
\hline $\begin{array}{c}\text { Lab. No. } \\
32\end{array}$ & $\begin{array}{l}\text { Paint. } \\
\text { IV }\end{array}$ & $\begin{array}{l}\text { Colour. } \\
\text { Red }\end{array}$ & $\begin{array}{l}\text { Lead. } \\
\text { Absent }\end{array}$ & $\begin{array}{c}\text { Zinc. } \\
\text { per cent. } \\
0.95\end{array}$ & $\begin{array}{c}\text { Copper } \\
\text { per cent. } \\
5 \cdot 79\end{array}$ & $\begin{array}{c}\text { Arsenic as } \\
\mathrm{As}_{4} \mathrm{O}_{6} \\
\text { per cent. } \\
0.01\end{array}$ \\
\hline 33 & I & Red & Absent & $0 \cdot 85$ & (cuprous) & 0.01 \\
\hline 34 & II & Green & Absent & $0 \cdot 04$ & $\begin{array}{c}16.56 \\
\text { (cupric) }\end{array}$ & $2 \cdot 60$ \\
\hline
\end{tabular}

No evidence of Mercury nor of Barium was obtained in any of the paints, but Nos. 32 and 33 contained large proportions of iron."

It is clear from these analyses that the paints I and IV are very much alike in constitution as in behaviour (see Table XV, p. 422) but contain very much less copper and arsenic than No. II. The combination of the metals zinc, copper, and arsenic in these paints with the respective percentages of approximately 1.0 zinc, 6 to 8 (cuprous) copper, and 0.01 per cent arsenic is one which is just approaching the limit of toxicity in seawater. This is a valuable result, even though the actual chemical constitution of the original materials is unknown.

The high percentage of cupric copper and arsenic remaining in paint II is sufficient explanation of the retained toxicity and a tribute to the efficiency of the matrix in this paint after 19 months' exposure on a shell surface in the sea. 


\section{Analyses of Paints on Test-Boards after about $3 \frac{1}{2}$ Years IN THE SEA.}

The paints II and IV on the test-boards used in Experiment F were analysed after remaining in the sea about $3 \frac{1}{2}$ years. The condition of these two test-boards with regard to overgrowth is given in detail in the section beginning on p. 410, and is depicted in Fig. 12, p. 404, and Fig. 13, p. 405 .

In the case of No. IV test-board, two areas of paint were scraped off and analysed. Both these areas had undoubtedly lost toxicity and were covered with living organisms when taken from the sea (see Fig. 12). The zinc-copper-arsenic percentage in these two samples of paint had been reduced greatly below that found to be near the limit of toxicity in the preceding sample, and had doubtless been non-toxic for some time, as may be also adjudged especially from the size of the barnacles (Balanus) which were growing on the analysed paint.

The condition with regard to overgrowths on the areas of paint, A to D, analysed from the front face of test-board II were as follows, but see also Fig. 12, p. 404.

\section{Site.}

Area A Around the fixing nail 10 to 18.4 inches from the top.

Area B $\begin{aligned} & 4 \cdot 5 \\ & \text { from }\end{aligned}$ to $8 \cdot 8$ inches Area C $\begin{aligned} & 10 \cdot 5 \\ & \text { from }\end{aligned}$ to $14 \cdot 7$ inches
Region.

In the upper middle region of the board.
Growth.

Covered in part with a growth of the hydroid Obelia and with a few borings of gribble in a crack in the wood.

the bottom of with 3 large and a few the board small borings of gribble, i.e. Limnoria or Chelura.

the bottom of No growth observable. the board, i.e. in the lower half.

Area D $5 \cdot 6$ to $9 \cdot 8$ inches from the top of the No growth observable. board.

The bottom of the board was covered with a growth of Diplosoma, Umbonula, and Halichondria up to a height of 5 or 6 inches from the lower edge ; this growth probably encroached slightly on the lower part of area $B$, which was scraped for chemical analysis.

The results of the analyses of the samples of paints scraped from areas A to $\mathrm{D}$ are given in the following report by the Government Chemist with a discussion on the significance of the figures obtained, together with analyses of the original paints from the paint-can. 
The Government Chemist's Report on Chemical Analyses.

"REPORT ON THE EXAMINATION OF TWO SAMPLES OF ANTIFOULING PAINT RECEIVED FROM DR. ORTON ON 15TH MARCH, 1923, AND OF THE PAINT REMAINING ON AREAS OF TWO WOODEN BOARDS TO WHICH THESE PAINTS HAD BEEN APPLIED WITH DIFFERING TOXIC

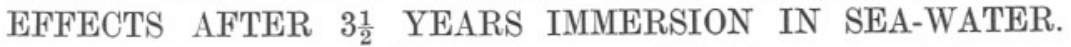

The paints were described as :-

Lab. No. 323. 1. (Green paint)

Lab. No. 324. 2. (Brown paint)

and gave the following results on analysis :-

TABLE 1.

Analyses of No. II and No. IV Original Paints.

Volatile matter (turpentine substitute)

Oil

Oxidised oil and varnish gums

Silica and silicates

Lead oxide

Arsenious oxide

Cupric oxide

Cuprous oxide

Iron oxide

Zine oxide

Calcium oxide

Carbon dioxide

Phosphoric pentoxide

Magnesium oxide

Sulphuric anhydride

Green
per cent.

(Reddish) brown

per cent.

per cent.

$18 \cdot 7$

$21 \cdot 6$

$8 \cdot 6$

$15 \cdot 9$

$1 \cdot 2$

$10 \cdot 5$

$0 \cdot 1$

$5 \cdot 6$

$5 \cdot 0$

$14 \cdot 8$

nil

$0 \cdot 4$

0.8

nil

0.2

nil
$11 \cdot 8$

$15 \cdot 4$

$8 \cdot 6$

0.5

$4 \cdot 6$

$9 \cdot 3$

$0 \cdot 2$

$0 \cdot 2$

$8 \cdot 3$

nil

$8 \cdot 6$

0.9

$5 \cdot 8$

matter (by difference)

$\underline{\underline{100 \cdot 0}}$

nil

nil

$\underline{\underline{100 \cdot 0}}$

In the green paint the copper appears to be present partly as insoluble basic sulphate (and some of the lime might also be linked up with this) and partly as aceto-arsenite of copper (Scheeles green). The calciumoxide is in combination with the carbon dioxide and with part of the sulphuric anhydride. It is impossible to give the exact composition of such a mixture.

In the case of the brown paint the copper is present in the form of red cuprous oxide and the calcium and magnesium oxides are in combination with the carbon dioxide forming carbonates.

The paint on the boards was very thin and only small quantities were obtained from the areas scraped. There was not sufficient material, therefore, for complete analyses. The most important constituents have 
been determined but the results are complicated by the fact that silicious material, carbonates, sodium salts, etc., have been deposited in the paint. Before scraping off the samples all organic growth was removed together with any incrustation that obviously did not belong to the paint. In the case of the brown board sample A was taken from a place competely overgrown, while the area sampled for B was fairly clean except for five or six barnacles.

Four areas of the green-painted board were marked A, B, C, and D by Dr. Orton, who stated that 'the part A has a growth of hydroids roughly within the circle,' and 'parts B, C, and D are apparently all just losing toxicity.'

The results of the analysis are as follows :-

Table 2.

Analyses of Paint Scrapings from Test-Boards II and IV. EXPERIMENT F,

\section{(a) Green board (II)}

Insoluble
in acid. $\left\{\begin{array}{c}\text { Oxidised oil, wood } \\ \text { and organic matter } \\ \text { Mineral matter, silica } \\ \text { and silicates }\end{array}\right.$ Cupric oxide

Iron oxide

Zinc oxide

Calcium oxide

Magnesium oxide

Arsenious oxide

Phosphorous pentoxide

Undetermined $-\mathrm{CO}_{2}$, chlorides, sulphates, moisture, soluble organic matter, and sodium salts

\section{(b) Brown board (IV)}

\begin{tabular}{|c|c|c|c|}
\hline $\begin{array}{c}\text { Partly } \\
\text { covered by } \\
\text { a growth } \\
\text { of hydroid. } \\
\text { A } \\
\% \\
14 \cdot 1\end{array}$ & $\begin{array}{c}\text { Bored by } \\
\text { gribble and } \\
\text { slightly } \\
\text { overgrown. } \\
\text { B } \\
\% \\
14 \cdot 5\end{array}$ & $\begin{array}{c}\text { No } \\
\text { growth. } \\
\text { C } \\
\% \\
12 \cdot 1\end{array}$ & $\begin{array}{c}\text { No } \\
\text { growth. } \\
\text { D } \\
\% \\
14 \cdot 4\end{array}$ \\
\hline $30 \cdot 8$ & $34 \cdot 8$ & $28 \cdot 8$ & $11 \cdot 2$ \\
\hline $4 \cdot 0$ & $2 \cdot 2$ & $7 \cdot 5$ & $15 \cdot 2$ \\
\hline $4 \cdot 5$ & $6 \cdot 3$ & $5 \cdot 0$ & $2 \cdot 4$ \\
\hline $0 \cdot 2$ & $0 \cdot 3$ & $0 \cdot 4$ & $0 \cdot 2$ \\
\hline $22 \cdot 6$ & $30 \cdot 4$ & $11 \cdot 2$ & $8 \cdot 5$ \\
\hline $1 \cdot 4$ & $1 \cdot 6$ & $1 \cdot 8$ & 0.9 \\
\hline $0 \cdot 4$ & trace & $0 \cdot 7$ & $0 \cdot 7$ \\
\hline $0 \cdot 6$ & 0.5 & $0 \cdot 3$ & $0 \cdot 3$ \\
\hline $21 \cdot 4$ & $9 \cdot 4$ & $32 \cdot 2$ & $46 \cdot 2$ \\
\hline $100 \cdot 0$ & $100 \cdot 0$ & $100 \cdot 0$ & $100 \cdot 0$ \\
\hline
\end{tabular}

\begin{tabular}{|c|c|c|}
\hline & & \\
\hline Insoluble ( Oxidised oil,wood and organic matter & $17 \%$ & 16.5 \\
\hline in acid. $\left\{\begin{array}{l}\text { Mineral matter, silica and silicates } \\
\text { inter }\end{array}\right.$ & $16 \cdot 9$ & $\begin{array}{l}16 \cdot 5 \\
19 \cdot 3\end{array}$ \\
\hline Cuprous oxide & $0 \cdot 2$ & $0 \cdot 6$ \\
\hline Iron oxide & $16 \cdot 4$ & $16 \cdot 0$ \\
\hline Zinc oxide & 0.5 & $0 \cdot 6$ \\
\hline Calcium oxide & $24 \cdot 2$ & $19 \cdot 2$ \\
\hline Magnesium oxide & $2 \cdot 6$ & $2 \cdot 2$ \\
\hline Arsenious oxide & nil & $0 \cdot 05$ \\
\hline Phosphorous pentoxide & $0 \cdot 4$ & $0 \cdot 3$ \\
\hline $\begin{array}{l}\text { Undetermined }-\mathrm{CO}_{2} \text {, chlorides, sulphates, } \\
\text { moisture, soluble organic matter and } \\
\text { sodium salts }\end{array}$ & $21 \cdot 3$ & $25 \cdot 3$ \\
\hline & $100 \cdot 0$ & $100 \cdot 0$ \\
\hline
\end{tabular}


It will be seen that in both sets of samples there are notable increases in the proportions of silicious material and calcium oxide while in the samples from the green board the iron has unaccountably increased.

In order to obtain a better comparison of the main inorganic constituents of the scrapings with those of the original paints the basic constituents (including silica and silicates and arsenic) have been added together and worked out on a 100 per cent basis. The figures are as follows :-

\section{TABLe 3.}

Percentage of Basic Constituents (including Silica, Silicates, and Arsenious Oxide) in the Original Paints II and IV and in Samples exposed in the Sea for $3 \frac{1}{2}$ Years.

(a) Green board (II)

Basic constituents (includ-

Original
paint.

$\%$

ing silica and silicates) $31 \cdot 1$

Silica and silicates

Lead oxide

Arsenious oxide

Cupric oxide

Iron oxide

Zinc oxide

Calcium oxide

Magnesium oxide

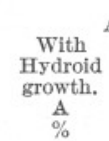

$63 \cdot 9$

Areas after $3 \frac{1}{1}$ years exposure in the sea.

$$
\begin{gathered}
\text { With } \\
\text { gribble } \\
\text { borings. } \\
\text { B } \\
\%
\end{gathered}
$$

$75 \cdot 5$

$46 \cdot 1$

nil

tce.

$2 \cdot 9$

$8 \cdot 3$

$0 \cdot 4$

$40 \cdot 2$

$2 \cdot 1$

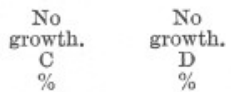

$55 \cdot 4$

$39 \cdot 0$

\begin{tabular}{rcccc}
$3 \cdot 9$ & $48 \cdot 2$ & $46 \cdot 1$ & $52 \cdot 1$ & $28 \cdot 7$ \\
$0 \cdot 3$ & nil & nil & nil & nil \\
$16 \cdot 1$ & $0 \cdot 6$ & tce. & $1 \cdot 2$ & $1 \cdot 7$ \\
$47 \cdot 5$ & $6 \cdot 3$ & $2 \cdot 9$ & $13 \cdot 5$ & $39 \cdot 0$ \\
$1 \cdot 3$ & $7 \cdot 0$ & $8 \cdot 3$ & $9 \cdot 1$ & $6 \cdot 0$ \\
$2 \cdot 6$ & $0 \cdot 3$ & $0 \cdot 4$ & $0 \cdot 7$ & $0 \cdot 6$ \\
$27 \cdot 6$ & $35 \cdot 4$ & $40 \cdot 2$ & $20 \cdot 1$ & $21 \cdot 7$ \\
$0 \cdot 7$ & $2 \cdot 2$ & $2 \cdot 1$ & $3 \cdot 3$ & $2 \cdot 3$ \\
\hline $100 \cdot 0$ & $100 \cdot 0$ & $\underline{100 \cdot 0}$ & $\underline{100 \cdot 0}$ & $\underline{100 \cdot 0}$ \\
\hline
\end{tabular}

(b) Brown board (IV)

Basic constituents (including silica and silicates)

Silica and silicates

Arsenious oxide

Cuprous oxide

Iron oxide

Zinc oxide

Calcium oxide

Magnesium oxide

\begin{tabular}{|c|c|c|}
\hline $\begin{array}{c}\text { Original } \\
\text { paint. } \\
\% \\
\%\end{array}$ & $\begin{array}{c}\text { Overgrown } \\
\text { area. } \\
\text { A } \\
\% \\
60.9\end{array}$ & $\begin{array}{c}\text { Overgrown } \\
\text { area. } \\
\text { B } \\
\% \\
57.9\end{array}$ \\
\hline $12 \cdot 8$ & $27 \cdot 8$ & $33 \cdot 2$ \\
\hline 0.5 & nil & $0 \cdot 1$ \\
\hline $27 \cdot 0$ & 0.4 & $1 \cdot 0$ \\
\hline $35 \cdot 2$ & $26 \cdot 9$ & $27 \cdot 7$ \\
\hline $1 \cdot 1$ & $0 \cdot 8$ & $1 \cdot 1$ \\
\hline $21 \cdot 3$ & $39 \cdot 8$ & $33 \cdot 1$ \\
\hline $2 \cdot 1$ & $4 \cdot 3$ & $3 \cdot 8$ \\
\hline $100 \cdot 0$ & $100 \cdot 0$ & $100 \cdot 0$ \\
\hline
\end{tabular}


The results from the green (arsenic) board are peculiar. Sample B contained the largest proportion of basic constituents and silica, i.e. 75.5 per cent, the bulk of this consisting of silica and silicates and calcium oxide.* Since practically all the arsenic and most of the copper have been washed out, this paint should have lost its toxicity to a greater extent than A which still contains $0 \cdot 6$ and $6 \cdot 3$ per cent respectively of arsenious oxide and copper oxide. Samples $\mathrm{C}$ and $\mathrm{D}$ should be more toxic than $\mathrm{A}$ and it will be seen that whereas in A and B there is an increase in the proportion of calcium oxide which is presumably due to shells* of minute organisms, the proportion in C and D is less than in the original paint, pointing to the paint surface still being obnoxious to the organisms. The proportion of basic constituents and silica in D is only $39 \cdot 0$ per cent as compared with 63.9 per cent in A.

The apparent increase in the iron content of the scrapings may have been caused by deposition of rust or some insoluble iron deposit from the sea water, or it may be due to the ferric oxide in the original paint being very much more resistant to the sea water than all the other constituents. of the paint.

In the case of the brown (copper) board it can be said that the cuprous. oxide has been almost completely washed out and there is little difference in the copper content on the area completely overgrown (A) and on the area only partially overgrown (B).

It is, however, practically impossible from the limited number of results to trace the changes which have occurred in the paints during exposure. The composition of the paint is affected on the one hand by removal of constituents, organic and inorganic, and on the other by addition of inorganic matter in the form of calcium carbonate and silicious. material derived either from the sea water or from organisms inseparable from the surface of the paint, or of organic matter, from the organisms. or from the underlying wood, which could not be separated from the scraped paint.

The results of the analysis of the paints on three shells which were given in the oyster mortality investigation report of 14th July, 1921, in terms of metallic copper and zinc may be stated, for comparison in terms. of the compounds found in the original paints as follows :-

$\begin{array}{lccccc}\text { Lab. No. } & \begin{array}{c}\text { No. of } \\ \text { paint. }\end{array} & \begin{array}{c}\text { Cuprous } \\ \text { oxide. } \\ \%\end{array} & \begin{array}{c}\text { Cupric } \\ \text { oxide. } \\ \%\end{array} & \begin{array}{c}\text { Zinc } \\ \text { oxide. } \\ \%\end{array} & \begin{array}{c}\text { Arsenious } \\ \text { oxide. } \\ \%\end{array} \\ 32 \text { (red) } & \text { IV } & 6 \cdot 52 & - & 1 \cdot 18 & 0 \cdot 01 \\ 33 \text { (red) } & \text { I } & 8 \cdot 91 & - & 1 \cdot 06 & 0 \cdot 01 \\ 34 \text { (green) } & \text { II } & - & 20 \cdot 71 & 0 \cdot 05 & 2 \cdot 60\end{array}$

* The excess of calcium oxide in this sample was probably derived from the encrusting Polyzoan on the lower part of area B (see p. 432). J. H. O. 
These results show that the brown paint on the shells had lost cuprous oxide, and the green paint had lost arsenic. The apparent increase of copper oxide in the green paint shows only that during its exposure to the sea the paint had lost less of its copper oxide than of other constituents. In illustration of the apparent increase it may be noted that if the original green paint had lost all its volatile matter and 3 per cent of arsenic, the remaining paint would contain 19.8 per cent of cupric oxide and $2 \cdot 6$ per cent of arsenic."

A. More.

June 14, 1923.

R.R.

\section{Biological Observations on the Government Chemist's Report.}

It is interesting to compare the biological observations which were made relating to a few points discussed in the preceding report by the Government Chemist. With regard to the sample B in the green testboard (II), the high proportion of basic constituents referred to is almost entirely due to calcium oxide (see Table 2 (a), p. 434). It is certain that this excess is due to the inclusion of the calcareous test of Umbonula (see p. 432) which was growing on the bottom of the board and was included in the scrapings from the lower part of area B.

The low percentage of copper and arsenic in this sample is reflected in the occurrence of borings of gribble in area B; these borings give therefore a biological confirmation to the chemical analyses, for they occur nowhere else on the surface of the areas scraped.

The area $\mathrm{A}$ was scraped over a rather greater extent than was intended, and it included a small space where the paint was retained as in area D. Hence the average toxic constituents in area A was slightly higher than would occur where the hydroid growth was well developed.

It is noteworthy that excepting area $\mathrm{A}$-which obviously became more rapidly denuded of paint due to the effect of the fixing nail-the areas B, C, and D form a graded series from bottom to top of the board in loss of arsenic and copper. This series is continued at the bottom of the board by a non-toxic area on which organisms were growing abundantly and where doubtless the arsenic and copper had been washed out to a very great extent. It has already been pointed out that this board was fixed vertically with the bottom a little below the level of low-water mark of spring tides; thus there had occurred a graded erosion of the paint from the region of low water to 3 feet above. As the bottom of the board would be almost constantly in water, it would seem that the erosion of the paint was due either to greater wave action at the bottom of the board or possibly, in this particular situation, to greater chemical interaction with the sea-water in proportion to the longer period of immersion at the different levels of the board. The other test-boards in 
this experiment also gave indication of maximum erosion at the bottom of the board (see Table IX, p. 402).

It is of interest to note that the reddish-brown paints have cuprous copper as the main toxic ingredient, while the green paint contains a large quantity of arsenious oxide, with a very high proportion of cupric copper, and with also rather more zinc than the aforementioned paints. The probable state of combination of these toxic ingredients is discussed in the Government Chemist's report (see p. 433).

\section{Discussion of the Results.}

The experiments herein described show clearly that a poisonous paint will inhibit the growth of marine animals for a period depending upon the retention of the paint on the surface it is desired to protect, and the existence in the paint of substances which maintain a toxic surface on the paint (see Table XV). It has been demonstrated that a dark green arsenic paint (II) remained toxic for a longer period than two red copper (IV and I) and one light green (arsenic) paint (XI), and that the durability of the matrix (oils, etc.) of the paint is a fundamental character of efficient paints. It is also clear that beyond a certain concentration of poison in a paint the durability of the matrix is more important than the nature of the toxic ingredient.

There can be little doubt that the best anti-fouling paints function through ionisation - and therefore loss - of the toxic ingredients.

Chemical analyses revealed the following facts with regard to a certain reddish-brown anti-fouling paint :-

Original paint (IV)

(a) Toxicity retained after 19 months' exposure in the sea.

\begin{tabular}{ccc}
\multicolumn{3}{c}{$\%$ Composition (approx.). } \\
$\begin{array}{c}\text { Arsenious } \\
\text { oxide. }\end{array}$ & $\begin{array}{c}\text { Cuprous } \\
\text { oxide. }\end{array}$ & $\begin{array}{l}\text { Zinc } \\
\text { oxide. }\end{array}$ \\
$0 \cdot 2$ & $11 \cdot 8$ & 0.5 \\
& & \\
0.01 & 6 to 8 & 0.8 to $1 \cdot 0$ \\
nil to & $0 \cdot 2$ to & 0.5 to \\
0.05 & 0.6 & 0.6
\end{tabular}

(b) Toxicity lost (some months previously) after $42 \frac{1}{2}$ months' exposure

Therefore the paint will remain toxic so long as it contains the ingredients of the order shown above in $(a)$. Another dark green paint showed on chemical analysis :-

Original paint (II)

(c) Toxicity retained after 19 months' exposure in the sea.

(d) Toxicity retained after $42 \frac{1}{2}$ months' exposure (C, fig. 13)

(e) Toxicity recently lost after $42 \frac{1}{2}$ months in the sea (A, fig. 13)

$\begin{array}{ccc}\begin{array}{c}\text { \% Composition (approx.) } \\ \text { Arsenious } \\ \text { oxide. }\end{array} & \begin{array}{l}\text { Cupric } \\ \text { oxide. }\end{array} & \begin{array}{l}\text { Zinc } \\ \text { oxide. }\end{array} \\ 5 \cdot 0 & 14 \cdot 8 & 0 \cdot 8 \\ 2 \cdot 6 & 16 \cdot 6 & 0 \cdot 04 \\ & & \\ 0.7 & 7 \cdot 5 & 0 \cdot 4 \\ 0.4 & 4 \cdot 0 & 0 \cdot 2\end{array}$


Thus in order to maintain toxicity a paint of this kind must retain a concentration of the poisonous ingredients not less than the values shown in $(d)$ above. In a similar way the combination of toxic ingredients which is necessary to inhibit growth of marine animals can be determined for any paint. The rate and nature of ionisation of the toxic ingredients at about the critical point for loss of toxicity has not been determined, but the non-toxic states of the two paints just noted indicate that a relatively high degree of ionisation of toxic substances is probably necessary to prevent the growth of animals on a surface in the sea. It has been pointed out that the results noted above were obtained under conditions more favourable than occur on the bottom of a ship where erosion plays a much more important rôle. In reviewing the extensive work done recently on this subject in America, Visscher $(16,1928)$ states that " Under optimum conditions vessels foul within 30 days of the time of dry-docking and the application of poisonous anti-fouling paints, indicating the hypothetical value of anti-fouling paints."

The experiment and observations herein described, however, indicate that good anti-fouling paints applied on a slightly roughened surface under dry conditions should give results which are definitely not hypothetical. It has, however; been demonstrated that great differences occur in the erosive value (i.e. degree of resistance to erosion) of antifouling paints (see Table XV, p. 422), and that paints such as VI or XI, be they ever so toxic, are probably of little value on the bottom of a ship. Hence the fundamental importance of the matrix of such paints. In the American work (loc. cit.) it would seem that the importance of the matrix has not been sufficiently recognised. It has been suggested herein that bacteria may be intimately concerned in breaking down both the matrix and toxic agents of a paint in the sea, and that researches on this subject are needed (see also Hillen, 24, who found bacteria in the "slime " on ships' bottoms). If bacteria prove to be important destructive agents, then the constituents of these paints should have a low energy potentiality value, as Matthews (17) showed in analogous work on bacteria in soils.

The nature of the surface to which paint will adhere best has been shown to be a slightly roughened surface (see Table XV, p. 422). A rough surface is, however, undesirable on the bottoms of ships owing to the increase of frictional effect, but it may be possible to devise a method of coating a roughened surface with paint so as to leave a finished smooth surface. Paints applied to a very smooth surface are eroded or flaked off very easily (see Table XV). On non-toxic surfaces little difference has been found in these and other experiments in the gross growth, whether the surface be smooth or rough (see passim herein the growth on black varnish, IX, and the white smooth inner surface of scallop shells 
on the one hand, and the growth on untreated wood and the outer rough surface of scallop shells on the other). I am, therefore, unable to agree with Visscher's remarks on this subject (16, p. 236), and consider that an alternative explanation is probable for each instance therein cited. It is obvious that the flaking of an anti-fouling paint will leave an area where organisms can and do settle (see especially Experiment $\mathrm{H}$ ) and form a point d'appui for still other organisms. This is no doubt what has occurred in the case cited by Visscher (loc. cit., Fig. 33в), and may be considered a silent tribute actually to the efficiency of the antifouling paint used in this particular case. The experiments described in these pages do, however, indicate that some hydroids-but not Tubularia - appear to grow better on a rough surface, but the evidence is not critical.

The effect of the nature of the light reflected from anti-fouling paints and other material has not been critically tested in these experiments, but in Experiments A to E heavy growths of Tubularia occurred within 6 weeks on greyish-white, red and black surfaces in subdued light. The correlated absence of growth on dark green and red poisonous surfaces is adequately proved to be due to the poisonous nature of these surfaces from the results of all the experiments. There can be little doubt that Tubularia will stick to any kind or colour of non-toxic surface in a subdued light, but the intensity of the light with regard to general growth is doubtless an important factor. In Experiment C, a growth of Algæ occurred on each of the green, red, and black painted and greyish-white untreated surfaces after 7 months' exposure (see Table III, p. 386), and a growth of Balanus occurred on a green paint in Experiment G after 9 months' exposure (see p. 415, and Holzapfel 25 and Visscher 16, p. 240). It is probable, however, that light colours in well-lighted situations prevent such larvæ as Pomatoceros, Hydroides, and allied Polychaetes, most Polyzoan larvæ, the cypris of Balanids and the tadpoles of Ascidians from settling on them readily, but the actinulæ of Tubularia and the planulæ of hydroids appear to stick to any surface with which they come in contact; while the spores of Algæ prefer and require some degree of light (see raft observation, p. 398); it is, moreover, probable that although the tadpoles of tunicates undoubtedly fix in the darker places on experimental material in the sea they probably meet sufficiently dark places to induce settlement in the microscopic shade afforded by such growths as hydroids at even moderate depths on light-coloured surfaces (see Table XIV, p. 416). It is therefore probable that-other things being equal, an equality difficult to obtain-a light-coloured anti-fouling paint may inhibit the growth of marine animals to a greater degree than a darker paint, but may be expected to acquire a relatively greater fouling from algæ. 
The surface of the paints exposed in the sea was observed and recorded. It was found that the best anti-fouling paints became eventually soft or powdery. The poorest paints became rapidly soft and easily eroded away, while the best paint, the dark green No. II, "powdered " very slowly and rubbed off slightly on the finger. Nos. IV and I paints remained hard - and clean-for many months but eventually became soft and eroded slowly. No. I eroded rather more quickly than IV. It is probable that the virtue in paint No. II lay in its capacity for powdering slowly and that the property is related mainly to the nature of the matrix, but possibly also to the interaction of the matrix and the toxic constituents. Any paint which relies on rapid erosion - and some are apparently constructed on this principle-is manifestly of little use on a vessel because of the rapid erosion (see Table XV, p. 422) to extinction.

It would appear that a soft or even slimy surface on a good durable anti-fouling paint is a necessity from the nature of the paint and its mode of functioning, and that it is therefore incompatible to strive for a hard and at the same time efficient poisonous paint. Visscher (loc. cit.) discusses the point from a different angle. He states that "the beneficial effects of the paints now used very probably can be attributed far more to the nature of the surface (when in water) than to any peculiarly poisonous property that they may possess. It seems that undue emphasis has been placed upon the use of poisons in paints on steel ships, which is probably a hold over from their use on wooden vessels, and that the proper nature of the surface film is the desired goal."

There can, however, be little doubt that the chemical analyses given of sea-exposed paints (at the beginning of this section, p. 438) at a point just before losing the power of inhibiting growth, and just after or at the instant of losing this power, is a demonstration of the dependence of these paints on toxicity for inhibiting growth. Therefore Visscher's conclusion is erroneous. The nature of the surface film of a paint may, however, be readily acknowledged as a property of primary importance.

On the Fundamental Properties of an Ideal Anti-Fouling Paint.

The experiments described in the foregoing pages have shown clearly that in order to maintain a painted surface free from marine growths it must be painted with a substance which requires to have three fundamental properties, namely :-

(1) It must adhere strongly to a surface which may be damp.

(2) It must present such a surface that marine organisms cannot exist on it (whether the surface be poisonous or otherwise).

(3) It must have the power of resisting erosion for a long period while retaining its inimical surface. 
The power of resisting erosion for a long period will depend to a great extent upon the nature of the matrix, but also on the value of the other ingredients for preserving the matrix while maintaining a (toxic) surface on which marine organisms cannot exist. It may be presumed that marine bacteria are significant organisms in the disintegration of the matrix (researches on the bacterial infection of anti-fouling paints at different epochs of exposure have, however, not been made) of a paint, and that therefore the best matrix would be one highly resistive to bacterial action, while at the same time resisting chemical interaction with sea-water.

It would therefore appear that beyond a certain concentration the toxicity of an anti-fouling paint is less important than the property of resisting erosion, that is the longevity of the matrix. A paint may be intensely poisonous, but it is of little value if the matrix is such that easy disintegration and/or erosion occurs in the sea. If, as is suggested, bacteria are primarily concerned in breaking down the matrix of a good paint in the sea, then it appears that a fundamental property of the matrix must be a low-energy potentiality value, as Matthews (17) found to be necessary in the case of substances capable of resisting bacteria in soils.

The review of the results of the experiments given in Table XV, p. 422, affords an opportunity to see how the fundamental properties of an ideal anti-fouling paint are distributed among the substances tested. But as the life of any paint in the sea must necessarily be short-in terms of years - being dependent upon the longevity of the matrix, it would appear that-failing the discovery of a permanent matrix - the problem of maintaining the bottom of ships clean and free from growths, for periods reckoned in years, must be solved by some other method than the application of paint.

\section{PART III. OBSERVATIONS ON THE GROWTHS ON THE BOTTOMS OF OCEAN-GOING AND LOCAL SHIPS.}

The following observations on the growth of marine organisms on the bottom of ocean-going and local ships within relatively short periods after being painted are useful as a practical indication of the inefficiency or efficiency of the paints used. In most of these cases the kind of paint used on the bottom of the ship was not known, but all were red in colour. If allowance be made, however, for the anti-fouling value of even inefficient paints the observations on the rapid growth of oceanic marine organisms and the transport of foreign organisms are well worth recording. Information regarding the duration and itinerary of the voyages 
and the last dates of repainting were obtained from the masters of the ships, to whom acknowledgment is gladly and warmly tendered.

s.v. Jarstein. Master, A. B. Axelsen. Examined at Plymouth September 2nd, 1913.

Painted with tar and a copper paint at Pelotas, South-east Brazil, May 16th, 1913, but only passed into salt water June 17th, 1913, on crossing the bar of Rio Grande (see the South American Pilot, Part I, p. 354, Admiralty).*

The following growths on the bottom of this ship were collected at Plymouth on September 2nd, 1913 ; the maximum age of this growth is therefore only eleven weeks :-

\begin{tabular}{|c|c|c|c|}
\hline Species. & $\begin{array}{l}\text { Length of } \\
\text { peduncle. }\end{array}$ & $\begin{array}{l}\text { Breadth of } \\
\text { capitulum. }\end{array}$ & $\begin{array}{c}\text { Sex } \\
\text { condition. }\end{array}$ \\
\hline Lepas Hilli & $35-60 \mathrm{~mm}$. & $13-20 \mathrm{~mm}$. & Mostly with ova \\
\hline Lepas anatifera & $29-55$, & $11-18$, & do. \\
\hline Conchoderma virgatum & $25-33$, & $9-10$, & $\begin{array}{l}\text { Mostly with ova } \\
\text { or embryos and } \\
\text { some with nau- } \\
\text { plii. }\end{array}$ \\
\hline
\end{tabular}

A specimen of Nautilograpsus minutus was taken on the stern of this ship, having a carapace width $11 \mathrm{~mm}$. and length $10.5 \mathrm{~mm}$., but may have either settled on the boat as a larva or at a later stage.

s.s. War Viceroy. 2nd Officer, G. Bryant. Examined at Plymouth, September 25th, 1919 .

Docked and painted March, 1919, at Cardiff; left Venice for Australia end of April, 1919; left Geelong for Plymouth, July, 1919, via Albany, Durban, Cape Town, St. Vincent, Cape de Verde Is., and arrived Plymouth, September, 1919. Average speed 8.2 knots, maximum $10 \frac{1}{2}$ and minimum $5 \frac{1}{2}$ knots.

The maximum age of the following is, therefore, about 5 months, i.e. May to September :-

Peduncle.

Lepas Hilli, length and breadth of capitulum $27 \times 16 \mathrm{~mm}$. ca. 22

Conchoderma virginatum do. $22 \times 15$,, ca. 25

, auritum do. $\quad 23 \times 14 \quad$,. ca. 36

Balanus sp. probably tintinabulum with test $20 \times 19 \mathrm{~mm}$., subcircular at base and height $18 \mathrm{~mm}$.

Tubularia sp. abundant.

* For this reference I am indebted to Commander Campbell Hepworth, the then Marine Superintendent of the Meteorological Office. 
Lepas and C. virginatum had embryos in the brood pouch, but C. auritum had only ova, which are apparently attached to the lining of the mantle cavity.

s.v. Miefield, Liverpool. Capt. Drummond. Examined at Plymouth, April 7-14th, 1913.

After spending about 6 weeks in fresh water at Buenos Aires and directly afterwards about 2 months in fresh water at Newcastle, N.S. Wales, this vessel returned to Plymouth via Anto-Fagasta, Chili, and Falmouth with only short periods at each of the ports. The ship was last painted on the bottom at Fiume, Austria, in June, 1911.

The age of the material cannot be given, but it is certainly not more than 4 or 5 months; growth doubtless began soon after leaving Australia on a bottom probably denuded of paint. The vessel was steel, not wood.

Conchoderma virgatum, some with embryos and nauplii with capitulum only $15 \times 10 \mathrm{~mm}$. and others much larger.

Conchoderma auritum, eggs in peduncle and apparently in the mantle lining (capitulum $25 \times 16 \mathrm{~mm}$., peduncle $50 \mathrm{~mm}$.)

Lepas anatifera, some with nauplii (capitulum $35 \times 21 \mathrm{~mm}$., peduncle $20 \mathrm{~mm}$.).

Lepas Hilli, some with nauplii (capitulum $30 \times 18 \mathrm{~mm}$.). Cellularia sp., Tubularia sp., and Amphipods in nests covered the bottom of the ship.

Nautilograpsus minutus, the Sargasso seaweed crab ; three specimens ; two escaped; one male with carapace width $10.5 \times 10 \mathrm{~mm}$. long.

Pilumnoides perlatus, a South American crab ; twenty-one specimens; some were soft and some were moulting in April ; the four largest specimens were males with carapace width $9 \mathrm{~mm}$.; seven others were males, seven others females, and three of undetermined sex. These specimens were exhibited at the Royal Society Soirées in 1913, and on August 26th, 1913 , the remaining females had grown to carapace breadth 12 to $14 \mathrm{~mm}$. $\times 9$ to $11 \mathrm{~mm}$. in length, and a male $9 \times 7 \mathrm{~mm}$.

Concholepas peruviana, a Chilean Gastropod, was taken (one specimen) creeping on the bottom of the vessel.

By adding powdered carmine to the water in which C. auritum was kept it was observed that water was drawn in at the auriculæ when the animal exserts its cirri, and expelled when the animal retracts into its shell. There can be no doubt therefore (as Darwin suggested, 26 II, p. 145) that one function of the auriculæ is connected with respiration. Observations are, however, required on the orientation of the auriculæ in relation to the direction of motion of the vessel and on the feeding mechanism, before the function of these peculiar organs can be understood. 


\section{s.v. MacMahon, Nantes. Capt. Guteguiz.}

This vessel was painted on April 15th, 1913, and examined for growth at Plymouth, October 17th to 20th, 1913, so that the maximum age of growths on the bottom is about 6 months, but as the paint would have some anti-fouling value, the actual age must be much less than this period. Lepas and Conchoderma, hydroids and spawning Nudibranchs were collected from the bottom of this vessel.

\section{s.s. Penolver. Capt. Bradshaw.}

This vessel was painted with a well-known red anti-fouling paint and left Barry Dock at the end of January, 1920. It arrived at Rio de Janeiro, February 25th, and left March 3rd, 1920; arrived Buenos Aires 9.3.20 and left 10.4.20 ; arrived St. Vincent 29.4.20 and left same day, reaching Plymouth May 12th, 1920. A few pedunculate barnacles were collected from this ship at Plymouth, May 19th, 1920, only $3 \frac{1}{2}$ months after being painted with an anti-fouling paint.

\section{s.s. Wotan. Master, Fred Hancock.}

This vessel was dry-docked and received two coats of anti-fouling paint at Glasgow, December, 1919, and proceeded to Barry, Malta, Constantinople, Sevastapol, Odessa, Salonica, Gibraltar, and thence to the River Plate, arriving there April 10th, 1920, and loaded up the River in fresh water. The ship sailed for Plymouth, May 1st, arriving June 7th, 1920.

A number of Lepas and Conchoderma, the latter of which were carrying embryos, as well as some South American crabs, were taken from the bottom of this vessel. These barnacles had undoubtedly grown since May 1st, that is in only 5 weeks and 2 days, and attained sexual maturity on a bottom painted so recently as $5 \frac{1}{2}$ months.

\section{s.s. London City.}

This vessel was docked and painted at West Hartlepool, April, 1910, towed round the coast to Brixham, and used there as a coal hulk. The bottom of this vessel was examined at Plymouth on August 1st, 1911, and an exceedingly luxuriant growth found of Tubularia, Pomatoceros, and other worms, numerous Echinus miliaris up to a diameter of $3 \mathrm{~cm}$.; abundant Sagartia viduata (=anguicoma) with a column uniformly ca. $20 \mathrm{~mm}$. in diameter and $4.5 \mathrm{~cm}$. high (preserved) ; numerous Dendronotus frondosus upwards to $40 \mathrm{~mm}$. long (preserved) were found feeding on the Tubularia larynx.

The maximum age of growth on the bottom of this vessel was 16 months, but the actual age must have been very much less for most of 
the growth, such as Echinus, Sagartia, and Dendronotus. For information regarding this vessel I am indebted to Mr. T. E. Gullett.

\section{s.s. Smeaton. Master, J. J. B. Hambley.}

This vessel cruised only locally and was observed over three docking and painting periods.

It was scraped and painted April 18th, 1912, and examined in dock on November 25th, 1912, only 7 months later. On the latter date a heavy growth was found of Balanus, mature Pomatoceros, larvigerous Bugula, Ciona up to $3.3 \mathrm{~cm}$. (extended) which gave larvæ on artificial fertilisation, Molgula which gave some segmenting eggs, and Anomia which gave some larvæ on artificial fertilisation.

On November 27th, 1912, the vessel was refloated and redocked April 23rd, 1913. On this date only a few patches of hydroids occurred on the bottom along with a few small Mytilus.

The contrast in these two periods, one summer and one winter, is very marked. The actual paint used is not known, but believed to be red oxide.

\section{S.s. Sir Walter Raleigh.}

Docking and painting occurred November 12th, 1912, and a subsequent redocking for painting May 14th, 1913, that is after 25 weeks. Only a very slight growth was again found, as occurred in the winter period with s.s. Smeaton. Two patches only of Tubularia occurred, a few Balanus, one colony of Bugula, two or three specimens of Pomatoceros, but many patches of a hydroid, probably Gonothyræa, up to 9 inches in diameter. The paint used in this case was probably also red oxide.

No. 1 buoy, timber with zine, G.W.R. Docks, Plymouth.

The date this buoy was put out is uncertain, but on the zinc and timber were numerous clear-tested Ascidiella up to $6.5 \mathrm{~cm}$. long, living and expanded, Ciona up to 8.6 and numerous smaller ones (expanded), much Botryllus, and fine long colonies of a hydroid, probably Obelia longissima. Similar zinc buoys exposed for two or more years acquire luxuriant growths similar to those described on the Cawsand Bay raft (see p. 398).

No. 10 buoy (iron), G.W.R. Docks, Plymouth, newly painted with red oxide, May 14th, 1913, was examined May 8th, 1914, and found to have only small Ascidiella, a few Mytilus, but large colonies of Botryllus and Diplosoma and a heavy growth of seaweeds. Heavy growths have been found on many similar buoys after exposure of the paint from 1 to 2 years. 


\section{ACKNOWLEDGMENTS.}

In the prosecution of the large amount of experimental field-work herein described, I am greatly indebted to Mr. Wm. Searle for valuable advice and willing assistance in many ways.

The chemical analyses undertaken by the Government Chemist and his staff in connexion with this work served the dual purpose of providing valuable additional data for these and other investigations. In so far as the chemical results obtained assist my own work, I owe and gladly tender thanks to those workers, and especially to Sir Robert Robertson.

For the photographs which illustrate the paper I have pleasure in thanking Mr. D. P. Wilson, who took most of his photos by flashlight, and Mr. A. J. Smith, and for other assistance in photography I gladly acknowledge help by Prof. J. S. Dunkerley and Dr. R. S. Clark. I am also indebted to Mr. F. S. Russell and Miss M. Lewis for assistance in reading the proofs.

\section{SUMMARY.}

Contemporaneously with extensive researches on the rate of growth and breeding in marine Invertebrates, observations were made on experimental material exposed in the sea for periods varying from 14 months to $3 \frac{1}{2}$ years to test the power of a number of paints and other substances (1) for inhibiting the growth of marine organisms, (2) for their preservation value, and (3) for their durability in sea-water. The experimental material was tested simultaneously in seven different habitats in three different localities on wood and on shells, which provided three essentially different types of surface.

The substances tested include proprietary anti-fouling and proprietary anti-corrosive paints, other anti-corrosive and preservation paints, coaltar, varnish, some common paints, sheet copper, and sheet zinc.

Observations were also made at Plymouth on the growth on the bottoms of ocean-going ships, and on local ships, buoys and rafts.

It was found that certain proprietary anti-fouling paints did not inhibit the growth of marine animals under the conditions of the experiments for more than a few weeks. Other similar paints inhibited the growth of marine animals for about 9 months, while others inhibited such growths for periods varying from 20 to $42 \frac{1}{2}$ months.

The so-called anti-fouling paint which inhibited growth only for a few weeks was non-toxic ; the paints which inhibited growth for longer periods were toxic, and their toxic property depends upon the maintenance in the paint of toxic ingredients of a certain concentration.

Some of the toxic paints eroded so rapidly that the prepared surfaces 
became denuded of paint before the toxic properties were lost : in other paints erosion occurred sufficiently slowly in some situations for the toxic effect to be lost before the paint was completely eroded. Chemical analysis of two paints which had been in the sea for 19 months without permitting overgrowth on the paint, and of the same two paints at a later epoch when overgrowth had occurred, or was just beginning, gave the following results :-

No. IV. Paint exposed 19 months without overgrowth

No. IV. Paint exposed $42 \frac{1}{2}$ months with overgrowth aged some months

\begin{tabular}{ccc}
\multicolumn{3}{c}{ Poisonous constituents. } \\
Percentage composition. \\
$\begin{array}{ccc}\text { Arsenious } & \text { Cuprous } & \text { Zine } \\
\text { oxide. } & \text { oxide. } & \text { oxide. }\end{array}$
\end{tabular}

No. II. Paint exposed 19 months without

No. II. Paint exposed $42 \frac{1}{2}$ months with-

$\begin{array}{ccc}0.01 & 6 \text { to } 8 & 0.8 \text { to } 1.0 \\ \text { nil to } & 0.2 \text { to } & 0.5 \text { to } \\ 0.05 & 0.6 & 0.6\end{array}$

\begin{tabular}{ccc}
\multicolumn{3}{c}{ Percentage composition. } \\
$\begin{array}{ccc}\text { Arsenious } & \text { Cupric } & \text { Zinc } \\
\text { oxide. } & \text { oxide. } & \text { oxide. }\end{array}$ \\
\end{tabular}
out overgrowth

$16 \cdot 6$

$0 \cdot 04$

do. do. with overgrowth

$\begin{array}{lll}0 \cdot 7 & 7 \cdot 5 & 0 \cdot 4 \\ 0 \cdot 4 & 4 \cdot 0 & 0 \cdot 2\end{array}$

These analyses fix for these particular paints the approximate limits of the toxic ingredients which are necessary to maintain toxicity, and also prove that these paints inhibit marine growths by maintaining a toxic influence at the surface of the paint.

In the case of the paints No. IV and No. II, which are shown to be good or excellent anti-fouling preparations, these paints, as well as other preparations, adhered well to the rougher surface of scallop shells and to glass-papered dry wood, but very badly to the smoother face of the scallop shells. Anti-fouling paints must therefore possess the following fundamental properties :-

1. Capacity to adhere to a surface, which in practice may be slightly damp.

2. Capacity to resist rapid erosion.

3. Capacity to prevent continuously - whether the vessel be stationary or in motion - the settlement and growth of the larvæ of marine organisms (a capacity usually attained by the incorporation of toxic ingredients).

Some of these fundamental properties may be modified to meet economic conditions, e.g. painting the bottoms of ships in dock in a hurry ; but some of the economic conditions must be modified to meet the inherent deficiences of anti-fouling paints, e.g. a sufficiently thick deposit of the 
paint must be applied to a dry and rough surface to ensure adherence, to resist erosion, and to maintain a toxic surface for a reasonable period.

It is pointed out that in order to resist erosion the body of the paint must be durable, and that the durability of the body may be largely conditioned by the attacks of marine bacteria and the energy available in that body. The body used in the construction of these paints is highly important, and the experiments described prove that certain proprietary anti-fouling paints are fundamentally deficient in possessing a body incapable of resisting even a moderate amount of exposure to sea water.

Thus the body of a paint may be more important than the toxic ingredients subject to the maintenance of a certain degree of toxicity.

It is shown that marine organisms can live and flourish adjacent to paint residues which give on chemical analysis high percentages of (presumably) toxic substances, but that further investigations are required to give the rate and degree of ionisation of the toxic ingredients at the surface of a paint at various epochs after the date of first exposure in the sea. Anti-fouling paints exposed to strong light permit growths much sooner than in subdued light, but in the former case the growth is marine algæ. It is pointed out that it is not clear whether this phenomenon is due to loss of toxicity in the paint due to the direct action of light, or to a greater resistive power of the spores of marine algæ to toxic agents. It is suggested that all toxic substances before or after combination with organic matter may be attacked by bacteria in the sea, and that such substances may therefore undergo a regular "life-history" of degradation and that in this respect copper may be short-lived.

The preservative properties of the substances (paints, coal-tar, etc.) were investigated on test-boards in one critical situation where wood is rapidly eaten away by gribble (i.e. Limnoria and Chelura). It was found that the substances range themselves into three categories.

A. Definitely anti-fouling and definitely preservative (on wood).

B. Non-anti-fouling but definitely preservative (on wood).

C. Slightly anti-fouling and slightly preservative (on wood).

It is pointed out that the experiments are subject to certain limitations in comparison with economic practice, in that none were carried out on iron. The variety of surface tested, however, permits proximal deductions regarding the behaviour of the substances on iron.

Thus Classes A and B (above) are-when properly applied-probably also good anti-corrosive agents on iron, as well as being valuable preservatives on wood.

Class C, in which occurs Red Oxide (of iron) - the commonest and most widely used of anti-corrosive paints for the bottom of iron ships,-is definitely shown to be of less value than either A or B on wood, and is also 
probably of less value than these on iron owing to weak resistance to erosion.

Class B includes common coal-tar, and common black varnish, while Class $\mathrm{C}$ includes, besides Red Oxide, certain proprietary anti-fouling and anti-corrosive paints and an ordinary aluminium paint.

Preservation is manifestly distinct from anti-fouling, though both may be effected by the same paint. The preservation of wood (by paints) can be ensured against " gribble," but not against Teredo, by common coal-tar and black varnish, to at least as great a degree as by the application of many special paints and "Red Oxide." On the other hand, well-dried coal-tar and black varnish give innocuous surfaces on which marine organisms establish themselves more readily in the sea than on untreated wood, the latter substance being usually slightly inimical to growths for a short period. It was found that all the paints and other substances adhered better to a rough than a smooth surface in all the experiments. Hence the conclusion that the bottoms of ships should be slightly roughened before the application of a paint, and the paint itself applied in such a way as to produce the smooth surface required for the reduction of friction. Coal-tar is proved to be a valuable preservative against gribble, but Teredo bored almost at once into wood which had been covered with two good coats of welldried coal-tar. In these cases the larvæ of Teredo had either bored through the coal-tar, or not improbably had found spots in the wood imperfectly covered with tar.

The paints in preliminary experiments were found to adhere less well to a damp than a dry surface; it is therefore recommended that after scraping and brushing, the bottoms of ships should be well hosed with fresh water and allowed to dry thoroughly (ideally) before the application of a paint.

The composition of an ideal anti-fouling paint is discussed, but the conclusion is reached that if the bottoms of ships are to be maintained free from growths for a period, stated in years, some other method must necessarily be used than the application of paint.

Observations are recorded of the rapid fouling of the bottoms of local ships treated in the spring with red oxide and relatively little after an equivalent period when treated in the autumn with the same material.

Heavy growths are recorded on rafts treated with coal-tar, slighter growths on buoys painted with a red paint, and on zinc buoys, within a period of about a year. A growth of Conchoderma and other barnacles which attained sexual maturity in a minimum period of 5 weeks and 2 days is recorded along with other rapid growths on ocean-going ships inspected at Plymouth. The capture of the Sargasso seaweed crab, Nautilograpsus minutus (=Planes), of the South American crab, Pilumnoides perlatus, and the Chilean Gastropod, Concholepas peruviana, on the bottoms of ships arriving at Plymouth is also recorded. 


\section{REFERENCES.}

1. Orton, J. H. Preliminary Account of a Contribution to an Evaluation of the Sea (Rate of Growth and Breeding of Invertebrata). Journ. Mar. Biol. Assoc., 10, 2, 1914.

2. - Sea-temperature Breeding and Distribution in Marine Animals. Journ. Mar. Biol. Assoc., 12, 2, 1920.

3. - Sex-phenomena in the Common Limpet (Patella vulgata). Nature, 104, p. 373, 1919-20.

4. - On the breeding habits of Echinus miliaris, with a Note on the feeding Habits of Patella vulgata. Journ. Mar. Biol. Assoc., 10, $2,1914$.

5. - The Production of living Clavellina Zooids in Winter by Experiment. Nature, 10\%, p. 75, 1921.

6. - On the rate of Growth of Cardium edule. Part I. Experimental Observations. Journ. Mar. Biol. Assoc., 14, 2, 1926.

7. - Observations on Patella vulgata. Part 1. Sex-phenomena, Breeding and Shell growth. Journ. Mar. Biol. Assoc., 15, 3, 1928.

8. —— Part II. Rate of Growth of Shell. loc. cit., 15, 3, 1928.

9. - - Report on a Survey of the Fal Estuary Oyster Beds (Nov. 1924). With Notes on the Biology of the Oyster. Falmouth (and Plymouth). 1926.

10. Plymouth Marine Invertebrate Fauna. Journ. Mar. Biol. Assoc., \%, 2, 1904.

11. Orton, J. H. Observations on Patella vulgata. Part III. Habitat and Habits. Journ. Mar. Biol. Assoc., 16, 1, 1929.

12. Pоттs, F. A. The Structure and Function of the Liver of Teredo. Proc. Camb. Phil. Soc. (Biol. Sci.), 1, 1923.

13. Barger, G. Report on the work of C. M. Yonge at Plymouth. The Deterioration of Structures in Sea-water. Fourth (Interim) Report of the Committee of the Institution of Civil Engineers (Dept. of Sci. and Indus. Research), 1924, p. 6.

14. Orton, J. H. An Account of Investigations into the Cause or Causes of the unusual Oyster Mortality in English Oyster Beds during 1920 and 1921. Fishery Investigations, London. Part I. Report, 6, 3, 1924 .

15. - Interim Report on Oyster Mortality Investigations, 1920; loc. cit. in 14, Part II, 6, 4, 1924. 
16. VIsscher, J. PAul. Nature and Extent of Fouling of Ships' Bottoms. Bull. Bur. of Fish, 43, Part II, 1927, Washington. Document No. 1031 (1928).

17. Matthews, A. Partial Sterilisation of Soil by Antiseptics. Journ. of Agric. Sci., 14, 1, 1924, Cambridge.

18. Stephenson, T. A. British Sea Anemones. Ray Soc., London, 1928.

19. Gruver, A. Monographie des Cirrhipedes. Paris, 1905.

20. Doflein, F. Lehrbuch der Protozoankunde, 1909.

21. Fischer, P. Manuel de Conchyliologie, 1887.

22. BeLL, J. History of British Stalk-eyed Crustacea, 1853.

23. Rathbun, M. J. Stalk-eyed Crustacea of Peru and adjacent Coast. Proc. U.S. National Mus., 38, 1910.

24. Hillen, G. J., and Angst, E. An Investigation of the habits of marine growths and (of the) toxic substances to be included in ships' bottom paints. Report Bureau of Construction and Repair. U.S. Navy Dept., Nov. 1923, Washington.

25. Holzapfes, A. C. The effect of light on the fouling of ships. Bulletin, American Bureau of Shipping, 3, 3, 1923. New York.

26. Darwin, C. A Monograph of the Cirripedia. Ray Soc., London. 1851.

27. Herdman, W. A., in Cambridge Nat. Hist., VII, p. 87.

28. Hartmeyer, R., in Bronn's Tierreich, Tunicata III, 1, p. 1455.

29. Aткins, W. R. G. The Hydrogen Ion Concentration of Sea Water in its Relation to Photo-synthetic Changes. Part II. Journ. Mar. Biol. Assoc., XIII, 1923, p. 97.

30. ORton, J. H. Some Experiments on Rate of Growth in a Polar Region (Spitzbergen) and in England. Nature, Vol. III, 1923, p. 146. 